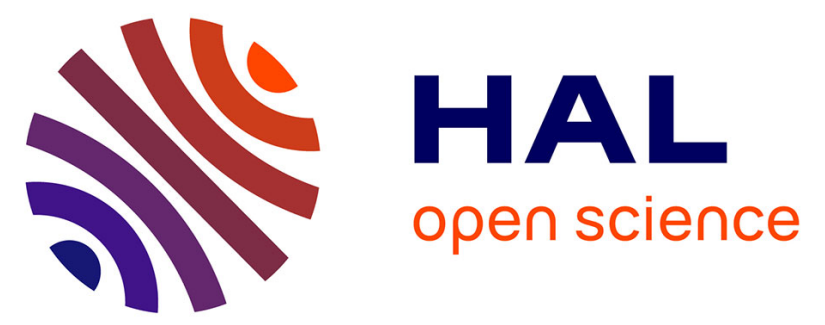

\title{
Efficiency of dihydroxamic and trihydroxamic siderochelates to extract uranium and plutonium from contaminated soils
}

Laureline Février, Frédéric Coppin, Sylvie Pierrisnard, Mélanie Bourdillon, Lé Vi Nguyen, Nissrine Zaiter, Stéphane Brandès, Vladimir Sladkov, Jean-Claude Chambron, Michel Meyer

\section{To cite this version:}

Laureline Février, Frédéric Coppin, Sylvie Pierrisnard, Mélanie Bourdillon, Lé Vi Nguyen, et al.. Efficiency of dihydroxamic and trihydroxamic siderochelates to extract uranium and plutonium from contaminated soils. Journal of Environmental Radioactivity, 2021, 235-236, pp.106645. 10.1016/j.jenvrad.2021.106645 . hal-03359316

\section{HAL Id: hal-03359316 https://hal.science/hal-03359316}

Submitted on 30 Sep 2021

HAL is a multi-disciplinary open access archive for the deposit and dissemination of scientific research documents, whether they are published or not. The documents may come from teaching and research institutions in France or abroad, or from public or private research centers.
L'archive ouverte pluridisciplinaire HAL, est destinée au dépôt et à la diffusion de documents scientifiques de niveau recherche, publiés ou non, émanant des établissements d'enseignement et de recherche français ou étrangers, des laboratoires publics ou privés.

\section{(ㅇ)(1) $\$$}

Distributed under a Creative Commons Attribution - NonCommercial - NoDerivatives 44.0 


\section{Efficiency of dihydroxamic and trihydroxamic siderochelates to extract uranium and plutonium from contaminated soils}

Laureline Février ${ }^{\mathrm{a}, *}$, Frédéric Coppin ${ }^{\mathrm{a}}$, Sylvie Pierrisnard ${ }^{\mathrm{a}}$, Mélanie Bourdillon ${ }^{\mathrm{b}}$, Lé Vi Nguyen ${ }^{\mathrm{b}}$, Nissrine Zaiter ${ }^{\mathrm{b}}$, Stéphane Brandès ${ }^{\mathrm{b}}$, Vladimir Sladkov ${ }^{\mathrm{c}}$, Jean-Claude Chambron ${ }^{\mathrm{d}}$, Michel Meyer ${ }^{\mathrm{b}, *}$

a Institut de Radioprotection et de Sûreté Nucléaire (IRSN), PSE-ENV/SRTE/LR2T, Centre d'Etudes Nucléaires de Cadarache, BP 3, 13115 Saint-Paul-Lez-Durance Cedex, France

b Institut de Chimie Moléculaire de l'Université de Bourgogne (ICMUB), UMR 6302, CNRS, Université Bourgogne-Franche-Comté, 9 avenue Alain Savary, BP 47870, 21078 Dijon Cedex, France

c Laboratoire de Physique des 2 Infinis Irène Joliot Curie (IJCLab), UMR 9012, CNRS/IN2P3 Université Paris-Saclay, Université de Paris, 15 rue Georges Clemenceau, 91405 Orsay, France

d Institut de Chimie de Strasbourg, UMR 7177, CNRS, Université de Strasbourg, 1 rue Blaise Pascal, BP 296 R 8, 67008 Strasbourg Cedex, France

Published on May 18, 2021 as an article in Journal of Environmental Radioactivity 2021, 235-236, 106645

DOI: 10.1016/j.jenvrad.2021.106645

as a part of the special issue "NEEDS-Environnement"

* Corresponding author.

E-mail addresses: laureline.fevrier@irsn.fr (L. Février), michel.meyer@u-bourgogne.fr (M. Meyer) 


\section{Highlights}

- Pu is efficiently extracted from artificially contaminated soils by desferrioxamine B

- An abiotic mimic of rhodotorulic acid extracted more efficiently naturally occurring $\mathrm{U}$ in soils than desferrioxamine $\mathrm{B}$ due to a lower affinity for $\mathrm{Fe}$

- After 1 day, citrate has extracted much more U and Pu from Fe-rich soils than hydroxamate siderochelates

- Due to degradation, the higher extractability power of citrate is lost after one week

\section{Keywords}

Actinides, citrate, hydroxamic acid, solid-liquid distribution, speciation

\section{Abstract}

Actinide-based mineral phases occurring in contaminated soils can be solubilized by organic chelators excreted by plants, such as citrate. Herein, the efficiency of citrate towards $\mathrm{U}$ and Pu extraction is compared to that of siderophores, whose primary function is the acquisition of iron(III) as an essential nutrient and growth factor for many soil microorganisms. To that end, we selected desferrioxamine B (DFB) as an emblematic bacterial trishydroxamic siderophore and a synthetic analog, abbreviated $\left(\mathrm{L}^{\mathrm{Cy}, \mathrm{Pr}}\right) \mathrm{H}_{2}$, of the tetradentate rhodotorulic acid (RA) produced by yeasts. Firstly, the uranyl speciation with both ligands was assessed in the $\mathrm{pH}$ range $2-11$ by potentiometry and visible absorption spectrophotometry. Equilibrium constants and absorption spectra for three $\left[\mathrm{UO}_{2}(\mathrm{DFB}) \mathrm{H}_{h}\right]^{(h-1)+}(h=1-3)$ and five $\left[\mathrm{UO}_{2}\left(\mathrm{~L}^{\mathrm{Cy}, \mathrm{Pr}}\right) \mathrm{H}_{h}\right]^{(2+h-2 l)+}(-1 \leq h \leq 1$ for $l=1$ and $h=0-1$ for $l=2)$ solution complexes were determined at $25.0{ }^{\circ} \mathrm{C}$ and $I=0.1 \mathrm{M} \mathrm{KNO}_{3}$. Similar studies for the $\mathrm{Fe}^{3+} /\left(\mathrm{L}^{\mathrm{Cy}, \mathrm{Pr}}\right)^{2-}$ system revealed the formation of five species having $\left[\mathrm{Fe}\left(\mathrm{L}^{\mathrm{Cy}, \mathrm{Pr}}\right)\right]^{+},\left[\mathrm{Fe}\left(\mathrm{L}^{\mathrm{Cy}, \mathrm{Pr}}\right) \mathrm{OH}\right],\left[\mathrm{Fe}\left(\mathrm{L}^{\mathrm{Cy}, \mathrm{Pr}}\right)(\mathrm{OH})_{2}\right]^{-}$, $\left[\mathrm{Fe}\left(\mathrm{L}^{\mathrm{Cy}, \mathrm{Pr}}\right)_{2} \mathrm{H}\right]$, and $\left[\mathrm{Fe}_{2}\left(\mathrm{~L}^{\mathrm{Cy}, \mathrm{Pr}}\right)_{3}\right]$ compositions. Then, the ability of DFB, $\left(\mathrm{L}^{\mathrm{Cy}, \mathrm{Pr}}\right) \mathrm{H}_{2}$, and citrate to solubilize either $\mathrm{U}$ or Pu from pitchblende-rich soils (soils 1 and 2) or freshly plutoniumcontaminated soils (LBS and PG) was evaluated by performing batch extraction tests. U was extracted significantly only by citrate after a day. After one week, the amount of $U$ complexed by citrate only slightly exceeded that measured for the siderochelates, following the order citrate $>\left(\mathrm{L}^{\mathrm{Cy}, \mathrm{Pr}}\right) \mathrm{H}_{2} \geq \mathrm{DFB} \approx \mathrm{H}_{2} \mathrm{O}$, and were comparatively very low. Pu was also more efficiently extracted by citrate than by DFB after a day, but only by a factor of $\sim 2-3$ for the PG soil, while the $\mathrm{Pu}$ concentration in the supernatant after one week was approximately the same for both natural chelators. It remained nearly constant for DFB between the $1^{\text {st }}$ and $7^{\text {th }}$ day, but 
drastically decreased in the case of citrate, suggesting chemical decomposition in the latter case. For the Fe-rich soils 1 and 2, the efficiencies of the three chelators to solubilize Fe after a day were of the same order of magnitude, decreasing in the order DFB > citrate $>\left(\mathrm{L}^{\mathrm{Cy}}, \mathrm{Pr}\right) \mathrm{H}_{2}$. However, after a week DFB had extracted $\sim 1.5$ times more Fe, whereas the amount extracted by the other chelators stayed constant. For the less Fe-rich LBS and PG soils contaminated by $\mathrm{Pu}$, the amounts of extracted Fe were higher, especially after 7 days, and the DFB outperformed citrate by a factor of nearly 3 . The higher capacity of the hexadentate DFB to extract Pu in the presence of $\mathrm{Fe}$ and its lower ability to mobilize $\mathrm{U}$ qualitatively agree with the respective complexation constant ratios, keeping in mind that both $\mathrm{Pu}$-containing soils had a lower iron loading. Noticeably, $\left(\mathrm{L}^{\mathrm{Cy}}, \mathrm{Pr}\right) \mathrm{H}_{2}$ has roughly the same capacity as DFB to solubilize $\mathrm{U}$, but it mobilizes less Fe than the hexadentate siderophore. Similarly, citrate has the highest capacity to extract $\mathrm{Pu}$, but the lowest to extract Fe. Therefore, compared to DFB, $\left(\mathrm{L}^{\mathrm{Cy}}, \mathrm{Pr}\right) \mathrm{H}_{2}$ shows a better $\mathrm{U} / \mathrm{Fe}$ extraction selectivity and citrate shows a better $\mathrm{Pu} / \mathrm{Fe}$ selectivity. 


\section{Introduction}

Siderophores are low molecular weight, water-soluble iron(III) chelators that are excreted by microorganisms, including bacteria and yeasts, to overcome the limited bioavailability of iron in soils. Their principal functions are to acquire ferric iron by dissolving poorly soluble iron minerals and oxides and to mediate the transport and deposition inside the cell of this essential nutrient. Among the $c a$. 500 siderophores isolated so far, various chelating groups have been identified, although the vast majority of them incorporate solely catecholate, hydroxamate, or $\alpha$-hydroxycarboxylate binding units able to form pseudo-octahedral high-spin iron(III) complexes (Boukhalfa and Crumbliss, 2002). The most ubiquitous siderophores found in nature are di- and trihydroxamic acids. Among them, desferrioxamine B (DFB, Fig. 1) is a bacterial linear hexadentate trihydroxamic acid produced by Streptomyces sp. (Neu et al., 2005), with a very high affinity for Fe(III) (Schwarzenbach and Schwarzenbach, 1963; Evers et al., 1989). Rhodotorulic acid (RA, Fig. 1), which is produced by yeasts of the Rhodotorula strain, belongs to the family of the linear tetradentate dihydroxamic ligands (Atkin and Neilands, 1968; Carrano et al., 1979). To reach a coordination number of six for iron, this compound forms a neutral diferric $\left[\mathrm{Fe}_{2}(\mathrm{RA})_{3}\right]$ triple helix, which dissociates into a red monocationic $[\mathrm{Fe}(\mathrm{RA})]^{+}$ dihydroxamato complex upon acidification of the medium. In general, tetradentate siderophores have a lower affinity for Fe(III) compared to hexadentate ones (Boukhalfa and Crumbliss, 2002). Because of the high affinity of hydroxamates for hard Lewis acid cations, like $\mathrm{Fe}^{3+}$ among others (Evers et al., 1989), siderophores are also able to bind effectively actinides, such as uranium (U), plutonium (Pu), thorium $(\mathrm{Th})$, or neptunium $(\mathrm{Np})$. Desferrioxamines and RA have been shown to form in vitro water-soluble complexes with Th(IV) (Whisenhunt et al., 1996; Keith-Roach et al., 2005; Sladkov et al., 2020), U(VI) (Groenewold et al., 2004; Mullen et al., 2007), and Pu(III/IV) (Boukhalfa et al., 2007; Jarvis and Hancock 1991; Neu et al., 2000). They can even dissolve $\mathrm{UO}_{2}, \mathrm{PuO}_{2}$, and the highly insoluble $\mathrm{Pu}(\mathrm{OH})_{4}$ phase (Neu et al., 2000; Ruggiero et al., 2002; Frazier et al., 2005).

While the interactions of siderophores with actinides have been extensively studied in model systems (with bacteria, yeast or pure mineral phases), less is known on their possible interactions in accidentally contaminated or natural uraniferous soils. As their concentration in the rhizosphere is typically in the $0.1 \mathrm{mg} \mathrm{kg}^{-1}$ range (Powell et al., 1980), it might be anticipated that these compounds could significantly increase the water solubility, migration rate, and bioavailability of highly toxic actinides in contaminated environments. Contamination of soils with actinides have occurred as a consequence of non-controlled releases during nuclear 
weapon tests (such as in the Nevada test site), nuclear fuel cycle operations, including mining and milling, or waste processing/disposal, such as in the Mayak, Hanford, or Savannah river sites for example (Novikov et al., 2006; Kaplan et al., 2007; Xu et al., 2015). Actinides are of major concern because of their high chemical toxicity and their radioactivity due to $\alpha$-particle emitting isotopes with relatively long half-lives. Therefore, the presence of actinide contaminants in soils or sediments raises the question of their mobility in the environment and the resulting risk of food chain contamination. In relation to the management and remediation of contaminated fields or the disposal of nuclear wastes in geological repositories (Essén et al., 2007), it is of upmost importance to gain a deeper understanding of the coordination chemistry of f-elements by siderophores and related chelators.

As part of an interdisciplinary research project on the fate of actinides $(\mathrm{U}, \mathrm{Pu})$ in naturally or artificially contaminated soils, the work presented herein had two main objectives. The first one was to unravel the speciation of uranium(VI) with the commercially available DFB and a synthetic linear dihydroxamic acid, labeled $\left(\mathrm{L}^{\mathrm{Cy}, \mathrm{Pr}}\right) \mathrm{H}_{2}$ (Fig. 1), that mimics RA. To that end, solution thermodynamic studies relying on potentiometric and spectrophotometric titration experiments were carried out in $0.1 \mathrm{M} \mathrm{KNO}_{3}$ solutions to determine the stoichiometry and stability of the various complexes prevailing in aqueous media over a large $\mathrm{pH}$ range. These studies were also extended to the $\mathrm{Fe}^{3+} /\left(\mathrm{L}^{\mathrm{Cy}}, \mathrm{Pr}\right)^{2-}$ system. Thermodynamic equilibrium constants, estimated by extrapolating the apparent experimental values from $I=0.1 \mathrm{M}$ to nil ionic strength, were used as input parameters of the JChess geochemical speciation code to calculate the mole fractions of the soluble $\mathrm{U}, \mathrm{Pu}$, and $\mathrm{Fe}$ species bound to the chelators in aqueous solutions. Their simplified analytical compositions were chosen so as to mimic those of the supernatant phases in contact with contaminated soil samples, with the aim of providing quantitative interpretations of the U/Pu dissolution tests. Indeed, our second objective was to assess the capacity of both chelators, DFB and $\left(\mathrm{L}^{\mathrm{Cy}, \mathrm{Pr}}\right) \mathrm{H}_{2}$, to extract $\mathrm{U}$ and $\mathrm{Pu}$ either from natural uraniferous soils or from freshly Pu-contaminated soils by performing desorption batch experiments. Their efficiencies were compared to those of citrate, which is another organic acid exudate of plants and well known to complex $\mathrm{U}$ and $\mathrm{Pu}$. 


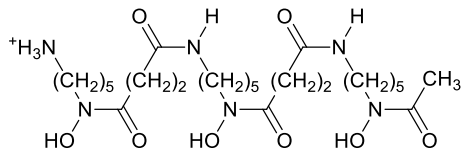

Desferrioxamine B (DFB)

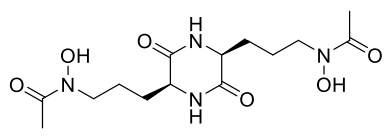

Rhodotorulic acid (RA)

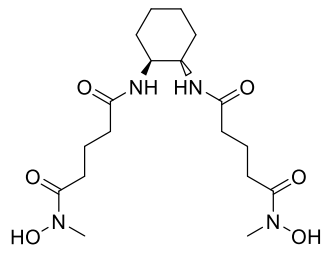

$(\mathrm{LCy}, \mathrm{Pr}) \mathrm{H}_{2}$

Fig. 1. Molecular formulae of the di- and trihydroxamic chelators discussed herein.

\section{Materials and methods}

\subsection{Uranium naturally rich soils}

Uranium extractions were performed on natural soils originating from La Creusaz/Les Marécottes (7 km west from Martigny) in Switzerland. This site is close to one of the most Uconcentrated pitchblende $\left(\mathrm{UO}_{2}\right)$ veins in Europe (Pfeifer et al., 1994). Two samples, denoted hereafter as soil 1 and soil 2 , have been collected in the A horizon of the soils $(0-15 \mathrm{~cm}$ following removal of the OL horizon, according to the classification proposed by Jabiol et al., 2013), homogenized, dried at room temperature, and sieved at $2 \mathrm{~mm}$ before use. The essential physico-chemical characteristics of both samples are reported in Table 1 (Henner et al., 2018). Briefly, they are sandy acidic soils, both classified as Colluviosol (Référentiel Pédologique, 2008), characterized by a high total U content reaching around $400-500 \mathrm{mg} \mathrm{kg}^{-1}$.

\section{Table 1}

Physico-chemical properties of the investigated soils.

\begin{tabular}{|l|l|l|l|l|}
\hline & Soil 1 & Soil 2 & LBS & PG \\
\hline Clay (\%) & 14.1 & 18.3 & 14.5 & 47.1 \\
\hline Loam (\%) & 28.5 & 35.8 & 56.5 & 39.4 \\
\hline Sand (\%) & 57.5 & 45.9 & 28.9 & 13.5 \\
\hline pH & 5.3 & 5.0 & 4.8 & 6.0 \\
\hline Organic matter (\%) & 10.96 & 11.95 & 2.84 & 13.4 \\
\hline Total U $\left(\mathrm{mg} \mathrm{kg}^{-1}\right)$ & 513 & 401 & - & - \\
\hline Activity of ${ }^{238} \mathrm{Pu}\left(\mathrm{Bq} \mathrm{kg}^{-1}\right)$ & - & - & $5.91 \times 10^{6}$ & $5.91 \times 10^{6}$ \\
\hline Total Fe $\left(\mathrm{g} \mathrm{kg}^{-1}\right)$ & 46.8 & 43.4 & 13 & 11 \\
\hline Fe Mehra-Jackson $\left(\mathrm{g} \mathrm{kg}^{-1}\right)$ & 20.3 & 19.8 & 6.85 & 5.25 \\
\hline
\end{tabular}




\subsection{Soils used for Pu experiments}

Plutonium extractions were performed on two artificially contaminated soil samples collected near Soulaines (Aube, France). The first, quoted LBS, is a leached brown forest soil, characterized by a silty texture (with only $14.5 \%$ of clays), whereas the second one, denoted PG, is a pseudogley forest soil with a clay texture (47.1\% of clay). As for the uranium enriched soils, they have been sampled in the 0-20 cm horizon (following removal of the OL horizon), dried at room temperature, and sieved at $2 \mathrm{~mm}$ before use.

Both LBS and PG samples were contaminated with $\mathrm{Pu}$ in stoppered polycarbonate (PC) centrifugation tubes $\left(\mathrm{Nalgene}^{\circledR}\right.$, Oak Ridge Style). Due to radioprotection constraints, $1 \mathrm{~g}$ of soil was used in each batch. The soil samples were continuously shaken during 14 days at 20 ${ }^{\circ} \mathrm{C}$ with $10 \mathrm{~mL}$ of a ${ }^{238} \mathrm{Pu}$ solution (the ${ }^{238} \mathrm{Pu}$ mother solution in $3 \mathrm{M} \mathrm{HNO}_{3}$ was provided by the CERCA-LEA laboratory of Orano), allowing a soil/volume ratio of 1/10. The soil was suspended in the test solution containing ${ }^{238} \mathrm{Pu}\left(7 \times 10^{5} \mathrm{~Bq} \mathrm{~L}^{-1}\right), \mathrm{Ca}\left(\mathrm{NO}_{3}\right)_{2}\left(2.5 \times 10^{-4} \mathrm{M}\right)$ and $\mathrm{NaNO}_{3}\left(2.5 \times 10^{-4} \mathrm{M}\right)$. After 14 days, the contaminated soils were separated from the solution by centrifugation, the supernatants discarded, and the batch reactors re-used for extraction of $\mathrm{Pu}$ from the contaminated soil pellets according to the procedure described in section 2.3. The $\mathrm{Pu}$ contamination level of each sample was determined from the difference between the ${ }^{238} \mathrm{Pu}$ concentration in the contamination solution at the beginning of the experiment and that remaining in solution after 14 days, assuming that no $\mathrm{Pu}$ was lost by adsorption on the vials used (vide infra). The mean activity of ${ }^{238} \mathrm{Pu}$ in the LBS and PG soils was $5.91 \times 10^{6} \mathrm{~Bq}_{\mathrm{kg}}{ }^{-1}$. Although this contamination level is far above those usually measured in natural environments, it is only about one half of the ${ }^{239 / 240} \mathrm{Pu}$-levels encountered in the highly contaminated soils of the Nevada Test sites (Francis and Dodge, 2015), while even higher activities $\left(1.2 \times 10^{9} \mathrm{~Bq} \mathrm{~kg}^{-}\right.$ ${ }^{1}$ ) can be measured for the bottom sediments of lake Karachay in Mayak (Ibragimov, 2020).

\subsection{Extraction experiments}

$\mathrm{Pu}$ batch extractions were performed in the same stoppered vials as the ones used for the contamination step. The soil residues recovered after centrifugation were suspended in $10 \mathrm{~mL}$ of the extracting solution. However, before adding the extracting solution, the batches were weighed to determine the quantity of residual soil solution remaining in the pellet after centrifugation. This quantity was taken into account in the calculation of $\mathrm{Pu}$ extraction yields. For the $\mathrm{U}$ extraction tests, $3 \mathrm{~g}$ of natural soil 1 or 2 were mixed with $30 \mathrm{~mL}$ of the extracting solution in the batch reactors (PC centrifugation tubes, Nalgene ${ }^{\circledR}$, Oak Ridge Style). All samples 
were continuously shaken during 7 days. At the end of the studied contact time, they were centrifuged and the recovered supernatants were filtered through $0.2 \mu \mathrm{m}$ membranes (Acrodisc ${ }^{\circledR}$ PF Syringe Filters with Supor ${ }^{\circledR}$ Membrane, Sterile - 0.8/0.2) before analysis. U extractions were performed in triplicate, while Pu extractions were duplicated only, to limit the amount of waste.

The extraction medium consisted either of ultra-pure water (UHQ, $18.2 \mathrm{M} \Omega \mathrm{cm}$ ) used as a reference or of $1 \mathrm{mM}$ solutions of either trisodium citrate dihydrate $\left(\mathrm{C}_{6} \mathrm{H}_{5} \mathrm{Na}_{3} \mathrm{O}_{7} \cdot 2 \mathrm{H}_{2} \mathrm{O}\right.$, VWR Chemicals), desferrioxamine B mesylate salt $\left(\mathrm{C}_{25} \mathrm{H}_{49} \mathrm{~N}_{6} \mathrm{O}_{8} \cdot \mathrm{CH}_{3} \mathrm{O}_{3} \mathrm{~S}\right.$, Sigma-Aldrich), or of the abiotic dihydroxamic acid $\left(\mathrm{L}^{\mathrm{Cy}, \mathrm{Pr}}\right) \mathrm{H}_{2}$. The synthesis of $\left(\mathrm{L}^{\mathrm{Cy}, \mathrm{Pr}}\right) \mathrm{H}_{2}$ and of its precursors, their ${ }^{1} \mathrm{H}$ and ${ }^{13} \mathrm{C}$ NMR spectra (Fig. S1-S3), and their analytical data can be found in the supplementary information file.

To quantify potential losses of Pu due to adsorption on the walls of the PC tubes or filters, blank adsorption test were conducted following the same protocol as above for soil contamination but without adding the soil samples. The ${ }^{238} \mathrm{Pu}$ concentration was measured after 14 days and revealed no adsorption on the tubes walls or filters. For U, previous experiments performed in our lab ruled out any adsorption on the used materials (PC tubes and filters) (Zeman et al., 2008; Guigues, 2010).

Extraction yields are expressed according to Eq. (1) as the amount of $\mathrm{U}$ or $\mathrm{Pu}$ in the supernatants at a given contact time relative to the total amount of $\mathrm{U} / \mathrm{Pu}$ present in the soil before the extraction.

$$
\text { Yield }=\frac{[\mathrm{U} / \mathrm{Pu}]_{\text {solution }, t}-[\mathrm{U} / \mathrm{Pu}]_{\text {solution }, t_{0}}}{[\mathrm{U} / \mathrm{Pu}]_{\text {soil }, t_{0}}} \times \frac{V}{m} \times 100
$$

In Eq. (1), $[\mathrm{U} / \mathrm{Pu}]_{\text {solution }}$ and $[\mathrm{U} / \mathrm{Pu}]_{\text {soil }}$ are expressed in $\mathrm{mol} \mathrm{L}^{-1}$ and mol kg${ }^{-1}$, respectively, $V$ stands for the volume of the extraction solution in $\mathrm{L}$ and $m$ for the mass of contaminated soil introduced in the batch reactor in $\mathrm{kg}$.

The distribution coefficient $\left(R_{\mathrm{d}}, \mathrm{L} \mathrm{kg}^{-1}\right)$ between the soil and the solution was calculated according to Eq. (2).

$$
R_{\mathrm{d}}=\frac{[\mathrm{U} / \mathrm{Pu}]_{\text {soil }}}{[\mathrm{U} / \mathrm{Pu}]_{\text {solution }}}
$$




\subsection{Chemical and radioanalytical analyses}

The uranium contents were measured by ICP-OES (Perkin Elmer Optima 4300DV, DL = $10 \mu \mathrm{g} \mathrm{L}^{-1}$ ) and those of plutonium by liquid scintillation after acidification of all samples with $2 \% v / v \mathrm{HNO}_{3}$ (Wallac Quantulus, $\mathrm{DL}=2.5 \mathrm{~Bq} \mathrm{~L}^{-1}$ ). For the $\mathrm{U}$ extraction tests, the amount of concomitantly released iron was determined by ICP-OES with the same equipment as above $\left(\mathrm{DL}=10 \mu \mathrm{g} \mathrm{L}^{-1}\right.$ ), whereas for the Pu extraction experiments iron was quantified by UV-vis

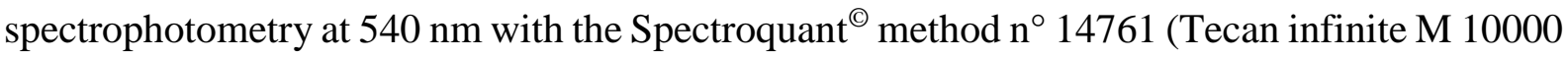
microplate reader, $\mathrm{DL}=200 \mu \mathrm{g} \mathrm{L}^{-1}$ ). The total citrate contents in solution were determined by ion chromatography (DIONEX-ICS3000, with a $4 \mathrm{~mm}$ AS suppressor, a $4 \mathrm{~mm}$ AG11-HC precolumn, and a $4 \mathrm{~mm}$ AS11-HC column) using a gradient from 1 to $45 \mathrm{mM} \mathrm{KOH}$ solution as eluent $\left(\mathrm{DL}=25 \mu \mathrm{g} \mathrm{L}^{-1}\right)$. The total amounts of $\mathrm{DFB}$ and $\left(\mathrm{L}^{\mathrm{Cy}, \mathrm{Pr}}\right) \mathrm{H}_{2}$ remaining in the supernatants were measured as their iron(III) complexes after addition of a $0.1 \mathrm{M} \mathrm{FeCl}_{3}$ solution to a sample aliquot. The mixtures were analyzed by UV-vis spectrophotometry at $480 \mathrm{~nm}$ using the microplate reader (linear calibration range: $0.2-2 \mathrm{mM}, \mathrm{DL}=5 \times 10^{-5} \mathrm{M}$ for DFB and $10^{-4} \mathrm{M}$ for $\left(\mathrm{L}^{\mathrm{Cy}, \mathrm{Pr}}\right) \mathrm{H}_{2}$ ). Unless otherwise noted (cf. solution thermodynamic studies), $\mathrm{pH}$ values, defined as $-\log a_{\mathrm{H}^{+}}$, were measured with a junction-free combined InLab Solids (Mettler-Toledo) $\mathrm{pH}$ electrode that was daily calibrated with commercial aqueous buffers $(\mathrm{pH}=4,7,10)$.

\subsection{Thermodynamic complexation studies}

All thermodynamic complex formation studies were performed in $0.1 \mathrm{M} \mathrm{KNO}_{3}$ solutions to maintain the ionic strength $(I)$ and thus the activity factors constants, while the temperature was set at $25.0 \pm 0.1{ }^{\circ} \mathrm{C}$. A slight argon overpressure prevented the ingress of $\mathrm{CO}_{2}$ in the headspace of the water-jacketed titration vessel. All solutions were prepared with doubledeionized ultrapure water $(18.2 \mathrm{M} \Omega \mathrm{cm})$ boiled for $2 \mathrm{~h}$ and saturated with Ar to eliminate traces of dissolved $\mathrm{CO}_{2}$. Stock solutions of supporting electrolyte $\left(0.1 \mathrm{M} \mathrm{KNO}_{3}\right)$, standardized $0.1 \mathrm{M}$ $\mathrm{HNO}_{3}$ and carbonate-free $0.1 \mathrm{M} \mathrm{KOH}$ prepared from Merck concentrates (Titrisol ${ }^{\circledR}$ ) were stored under Ar. The uranyl mother solution $(c=0.0324(5) \mathrm{M})$ was obtained by dissolving an exactly weighed amount of $\left[\mathrm{UO}_{2}\left(\mathrm{NO}_{3}\right)_{2}\left(\mathrm{H}_{2} \mathrm{O}\right)_{2}\right] \cdot 4 \mathrm{H}_{2} \mathrm{O}$ in $0.100 \mathrm{M} \mathrm{HNO}_{3}$ and its concentration checked by polarography (Sornosa-Ten et al., 2018). The iron stock solution, prepared by dissolving $\mathrm{Fe}\left(\mathrm{NO}_{3}\right)_{3} \cdot 6 \mathrm{H}_{2} \mathrm{O}$ (Alfa-Aesar, 99.9\%) in $0.100 \mathrm{M} \mathrm{HNO}_{3}$, was standardized by complexometry using a certified $0.100 \mathrm{M} \mathrm{Na}_{2} \mathrm{H}_{2}$ EDTA solution (Titrisol ${ }^{\circledR}$, Merck). Ligand solutions were prepared by careful weighing with a Precisa 262SMA-FR balance (resolution: $\pm 0.01 \mathrm{mg})$. 
The detailed procedure and equipment used to perform potentiometric and direct spectrophotometric titrations has been described in detail elsewhere (Sornosa-Ten et al., 2018). Briefly, pH measurements were carried out with a PHM 240 ionometer (Radiometer) connected to a XG100 (Radiometer) glass electrode and a KCl-saturated XR110 calomel electrode (Radiometer), separated from the test solution by a sintered-glass salt bridge filled with $0.1 \mathrm{M}$ $\mathrm{KNO}_{3}$. The measuring cell was calibrated prior to each experiment in terms of hydronium ion concentrations $\left(\mathrm{p}[\mathrm{H}]=-\log \left[\mathrm{H}_{3} \mathrm{O}^{+}\right]\right)$by performing a $\mathrm{HNO}_{3} / \mathrm{KOH}$ titration in $0.1 \mathrm{M} \mathrm{KNO}_{3}\left(\mathrm{p} K_{\mathrm{w}}\right.$ $=13.78$ at $\left.25.0{ }^{\circ} \mathrm{C}\right)$. To account for the liquid junction potential in the acidic $\left(E_{\mathrm{ja}} \approx J_{\mathrm{a}}\left[\mathrm{H}_{3} \mathrm{O}^{+}\right]\right)$ and alkaline $\left(E_{\mathrm{jb}} \approx J_{\mathrm{b}}\left[\mathrm{OH}^{-}\right]\right)$regions, electromotive forces $\left(E_{\mathrm{mes}}\right)$ recorded at $\pm 0.1 \mathrm{mV}$ resolution were expressed as a function of $\mathrm{p}[\mathrm{H}]$ according to the modified Nernst equation (Eq. (3)) over the $\mathrm{p}[\mathrm{H}]$ range $1.8-11.9$.

$$
E_{\mathrm{mes}}=E^{0}-S \mathrm{p}[\mathrm{H}]+J_{\mathrm{a}} 10^{-\mathrm{p}[\mathrm{H}]}+J_{\mathrm{b}} K_{\mathrm{w}} 10^{\mathrm{p}[\mathrm{H}]}
$$

The standard potential $\left(E^{0}\right)$, the slope $(S)$ of the glass electrode, together with $J_{\mathrm{a}}, J_{\mathrm{b}}$, and the base concentration factor were allowed to refine by non-linear least squares using the Solver function implemented in Microsoft Excel.

For all potentiometric and spectrophotometric titrations, special care was taken to ensure that equilibrium was reached prior to data acquisition, by cycling the titrations from low to high $\mathrm{p}[\mathrm{H}]$ and vice-versa. More details about the data processing and refinement of the apparent global stability constants (Eq. (4)) with the Hyperquad program (Protonic Software; Gans et al., 1996) can be found in previous publications (Meyer et al., 2007; Sornosa-Ten et al., 2018). Global stability constants, denoted $\beta_{m l h}$, are associated to the overall complex formation equilibrium (5).

$$
\begin{aligned}
& \beta_{m l h}=\frac{\left[\mathrm{M}_{m} \mathrm{~L}_{l} \mathrm{H}_{h}\right]}{[\mathrm{M}]^{m}[\mathrm{~L}]^{l}[\mathrm{H}]^{h}} \\
& m \mathrm{M}+l \mathrm{~L}+h \mathrm{H} \leftrightarrows \mathrm{M}_{m} \mathrm{~L}_{l} \mathrm{H}_{h}
\end{aligned}
$$

The indices $m, l$, and $h$ stand for the stoichiometric coefficients of the hydrated metal cation (M) of charge $z_{M^{+}}$, the fully deprotonated anionic ligand (L) of charge $z_{\mathrm{L}}^{-}$, and of the proton $\left(\mathrm{H}^{+}\right)$, respectively. Metal ion or complex hydrolysis reactions (Eq. (6)) are written as:

$$
m \mathrm{M}+l \mathrm{~L}+h \mathrm{H}_{2} \mathrm{O} \leftrightarrows \mathrm{M}_{m} \mathrm{~L}_{l}(\mathrm{OH})_{h}+h \mathrm{H}
$$




$$
\beta_{m l-h}=\frac{\left[\mathrm{M}_{m} \mathrm{~L}_{l}(\mathrm{OH})_{h}\right][\mathrm{H}]^{h}}{[\mathrm{M}]^{m}[\mathrm{~L}]^{l}}
$$

Competition batch titrations of $\left[\mathrm{Fe}\left(\mathrm{L}^{\mathrm{Cy}, \mathrm{Pr}}\right)\right]$ by $\mathrm{Na}_{2} \mathrm{H}_{2} \mathrm{EDTA}$ were performed in triplicate at a $\mathrm{p}[\mathrm{H}]$ of 2.80 in $0.05 \mathrm{M}$ chloroacetic acid/chloroacetate $\left(\mathrm{p} K_{\mathrm{a}}=2.85\right)$ buffer containing the required amount of $\mathrm{KNO}_{3}$ to adjust the ionic strength to $I=0.1 \mathrm{M}$ (Perrin and Dempsey, 1974). A $4 \times 10^{-3} \mathrm{M}$ mother solution of $\left[\mathrm{Fe}\left(\mathrm{L}^{\mathrm{Cy}}, \mathrm{Pr}\right)\right]$ was prepared in a volumetric flask by mixing a weighed amount of ligand with the exact equimolar quantity of standardized $\mathrm{Fe}\left(\mathrm{NO}_{3}\right)_{3} \cdot 6 \mathrm{H}_{2} \mathrm{O}$ stock solution and buffer. The commercial $0.100 \mathrm{M}$ solution of $\mathrm{Na}_{2} \mathrm{H}_{2}$ EDTA (Merck) was diluted with buffer to reach a final concentration of $2 \times 10^{-3} \mathrm{M}$. Then, a series of 32 samples was prepared in $5 \mathrm{~mL}$ volumetric flasks by introducing $0.25 \mathrm{~mL}$ of the $\left[\mathrm{Fe}\left(\mathrm{L}^{\mathrm{Cy}, \mathrm{Pr}}\right)\right]$ solution in each vial $\left(c=2 \times 10^{-4} \mathrm{M}\right)$, between 0 and $1.25 \mathrm{~mL}$ of the diluted $\mathrm{Na}_{2} \mathrm{H}_{2}$ EDTA solution $(c=0$ $\left.5.0 \times 10^{-4}\right)$, and the required volume of buffer solution to reach the mark. The tightly stoppered, argon-purged flasks were kept for 3 days at a constant temperature of $25.0 \pm 0.2{ }^{\circ} \mathrm{C}$ in a water bath equipped with an immersion thermostat (Lauda). The absorption spectrum of an extra control sample was checked from time to time to ensure that equilibrium was reached. All spectra were collected after 3 days with a $1 \mathrm{~cm}$ Suprasil cuvette (Hellma) on a Cary 50 (Varian) spectrophotometer, equipped with a double-walled cell holder that was connected to a Lauda RE106 water circulator set at $25.0 \pm 0.1{ }^{\circ} \mathrm{C}$. The equilibrium $\mathrm{p}[\mathrm{H}]$ of all samples was checked and did not deviate by more than 0.05 unit from the set value of 2.80. Spectrophotometric data were evaluated with the Specfit software (Gampp et al., 1985a, 1985b) by maintaining fixed all auxiliary equilibrium constants taken at $I=0.1 \mathrm{M}$ and $25.0{ }^{\circ} \mathrm{C}$. The protonation constants of $\left(\mathrm{L}^{\mathrm{Cy}, \mathrm{Pr}}\right)^{2-}$ were determined herein, those of $\mathrm{EDTA}^{4-}\left(\log \beta_{01 h}=10.19,16.32,19.01,21.01\right.$, and 22.51 for $h=1-5)$, as well as the iron binding constants $\left(\log \beta_{110}=25.1, \log \beta_{111}=26.4, \log \right.$ $\left.\beta_{11-1}=17.71\right)$, were all retrieved from the critical compilation of Martell et al. (2004).

\subsection{Thermodynamic modelling}

To get a deeper understanding of the $\mathrm{U} / \mathrm{Pu}$ dissolution results, the $\mathrm{U}, \mathrm{Pu}, \mathrm{Fe}$, and siderochelate speciation in the test solutions after 7 days of contact was simulated with the JChess 2.0 software (Van der Lee and De Windt, 1999). For that purpose, complexation constants $\left(\beta_{m l h}\right)$ at $I=0.1 \mathrm{M}$ ionic strength were either retrieved from the literature for both $\mathrm{Fe}^{3+} / \mathrm{DFB}^{3-}$ (Evers et al., 1989) and $\mathrm{Pu}^{4+} / \mathrm{DFB}^{3-}$ (Boukhalfa et al., 2007) systems, or determined herein for $\mathrm{UO}_{2}{ }^{2+} / \mathrm{DFB}^{3-}$, $\mathrm{UO}_{2}{ }^{2+} /\left(\mathrm{L}^{\mathrm{Cy}}, \mathrm{Pr}\right)^{2-}$, and $\mathrm{Fe}^{3+} /\left(\mathrm{L}^{\mathrm{Cy}}, \mathrm{Pr}\right)^{2-}$. JChess uses thermodynamic equilibrium constants $\left(\beta^{\circ}{ }_{m l h}\right)$ as input parameters, and corrects them at each iteration for the ionic strength effects by approximating the activity coefficients of charged species with the 
Davies equation given by Eq. (8). Therefore, the same expression was used also to extrapolate to $I=0$ all apparent equilibrium constants determined at $I=0.1 \mathrm{M}$ and $25^{\circ} \mathrm{C}$.

$$
\log {\beta_{m l h}^{\circ}}_{m} \log \beta_{m l h}-0.509 \Delta z^{2}\left(\frac{\sqrt{I}}{1+\sqrt{I}}-0.3 I\right)=\log \beta_{m l h}-0.107 \Delta z^{2}
$$

with $\Delta z^{2}=\left(m z_{\mathrm{M}}-l z_{\mathrm{L}}+h\right)^{2}-m z_{\mathrm{M}}^{2}-l z_{\mathrm{L}}^{2}-h$

These $\beta^{\circ}{ }_{m l h}$ estimates were then implemented in the database already used by Lofts et al. (2015) and Vercouter et al. (2015). Briefly, this database is an update of the one released in 2004 in the framework of the Common Thermodynamic Database Project (Van der Lee and Lomenech, 2004). It merges critical thermodynamic data for uranyl reviewed by Denison (2002) and Denison and Garnier-Laplace (2005) and the default JChess database, supplemented with the stability constants for the complexes $\mathrm{MgUO}_{2}\left(\mathrm{CO}_{3}\right)_{3}{ }^{2-}, \quad \mathrm{CaUO}_{2}\left(\mathrm{CO}_{3}\right)_{3}{ }^{2-}$, $\mathrm{Ca}_{2} \mathrm{UO}_{2}\left(\mathrm{CO}_{3}\right)_{3}, \mathrm{SrUO}_{2}\left(\mathrm{CO}_{3}\right)_{3}{ }^{2-}$, and $\mathrm{Sr}_{2} \mathrm{UO}_{2}\left(\mathrm{CO}_{3}\right)_{3}$ reported by Dong and Brooks $(2006,2008)$ and Geipel et al. (2008).

\section{Results}

\subsection{Complexation constants of $U$ with DFB and $\left(L^{C y, P r}\right) H_{2}$}

Solution complexation studies at equilibrium are a powerful means to gain a deep knowledge on the number, composition (molecular formula), and stability of species formed under given experimental conditions, such as $\mathrm{pH}$, total metal, and ligand concentrations. Glasselectrode potentiometry is a well-established technique for that purpose, although coupling $\mathrm{pH}$ to UV-vis spectrophotometric measurements can provide additional valuable structural information. As the derived thermodynamic data allow to model, and thus predict, the species distribution in multicomponent systems at equilibrium, herein a U/Pu contaminated soil suspended in a water phase containing a solubilized metal-ion chelator, the essential equilibrium constants missing in the literature were carefully determined before performing the batch dissolution tests. Hence, global protonation and uranyl binding constants $\left(\beta_{m l h}\right)$ were measured in aqueous solutions for both considered siderochelates, DFB (Table 2) and $\left(\mathrm{L}^{\mathrm{Cy}}{ }^{\mathrm{Pr}}\right) \mathrm{H}_{2}$ (Table 3), while the iron(III) speciation with the latter ligand was also investigated (Table 3). 


\section{Table 2}

Conditional $\left(\beta_{m l h}\right)$ and thermodynamic $\left(\beta^{\circ}\right.$ mlh $)$ protonation and complexation constants for $(\mathrm{DFB})^{3-}$ with $\mathrm{Fe}^{3+}, \mathrm{UO}_{2}{ }^{2+}$, and $\mathrm{Pu}^{4+}$.

\begin{tabular}{llll}
\hline $\mathrm{Reaction}$ & $\log \beta_{m l h}$ & $\Delta z^{2}$ & \multicolumn{1}{c}{$\log \beta^{\circ} m l h$} \\
\hline$(\mathrm{DFB})^{3-}+\mathrm{H}^{+} \leftrightarrows(\mathrm{DFB}) \mathrm{H}^{2-}$ & $11.06(2)^{\mathrm{b}}$ & -6 & 11.70 \\
$(\mathrm{DFB})^{3-}+2 \mathrm{H}^{+} \leftrightarrows(\mathrm{DFB}) \mathrm{H}_{2}{ }^{-}$ & $20.75(2)^{\mathrm{b}}$ & -10 & 21.82 \\
$(\mathrm{DFB})^{3-}+3 \mathrm{H}^{+} \leftrightarrows(\mathrm{DFB}) \mathrm{H}_{3}$ & $29.70(3)^{\mathrm{b}}$ & -12 & 30.98 \\
$(\mathrm{DFB})^{3-}+4 \mathrm{H}^{+} \leftrightarrows(\mathrm{DFB}) \mathrm{H}_{4}^{+}$ & $38.06(3)^{\mathrm{b}}$ & -12 & 39.34 \\
$\mathrm{Fe}^{3+}+(\mathrm{DFB})^{3-} \leftrightarrows[\mathrm{Fe}(\mathrm{DFB})]$ & $30.99^{\mathrm{c}}$ & -18 & 32.92 \\
$\mathrm{Fe}^{3+}+(\mathrm{DFB})^{3-}+\mathrm{H}^{+} \leftrightarrows[\mathrm{Fe}(\mathrm{DFB}) \mathrm{H}]^{+}$ & $41.39^{\mathrm{c}}$ & -18 & 43.32 \\
$\mathrm{Fe}^{3+}+(\mathrm{DFB})^{3-}+2 \mathrm{H}^{+} \leftrightarrows\left[\mathrm{Fe}(\mathrm{DFB}) \mathrm{H}_{2}\right]^{2+}$ & $42.33^{\mathrm{c}}$ & -16 & 44.04 \\
$\mathrm{UO}_{2}{ }^{2+}+(\mathrm{DFB})^{3-}+\mathrm{H}^{+} \leftrightarrows\left[\mathrm{UO}{ }_{2}(\mathrm{DFB}) \mathrm{H}^{3+}\right.$ & $27.5(1)^{\mathrm{b}}$ & -14 & 29.0 \\
$\mathrm{UO}_{2}{ }^{2+}+(\mathrm{DFB})^{3-}+2 \mathrm{H}^{+} \leftrightarrows\left[\mathrm{UO}{ }_{2}(\mathrm{DFB}) \mathrm{H}_{2}\right]^{+}$ & $33.8(1)^{\mathrm{b}}$ & -14 & 35.3 \\
$\mathrm{UO}_{2}{ }^{2+}+(\mathrm{DFB})^{3-}+3 \mathrm{H}^{+} \leftrightarrows\left[\mathrm{UO}{ }_{2}(\mathrm{DFB}) \mathrm{H}_{3}\right]^{2+}$ & $37.5(1)^{\mathrm{b}}$ & -12 & 38.8 \\
$\mathrm{Pu}^{4+}+(\mathrm{DFB})^{3-} \leftrightarrows[\mathrm{Pu}(\mathrm{DFB})]^{+}$ & $38.39^{\mathrm{d}}$ & -24 & 40.96 \\
$\mathrm{Pu}^{4+}+(\mathrm{DFB})^{3-}+\mathrm{H}^{+} \leftrightarrows[\mathrm{Pu}(\mathrm{DFB}) \mathrm{H}]^{2+}$ & $45.04^{\mathrm{d}}$ & -22 & 47.39 \\
$\mathrm{Pu}^{4+}+(\mathrm{DFB})^{3-}+2 \mathrm{H}^{+} \leftrightarrows\left[\mathrm{Pu}(\mathrm{DFB}) \mathrm{H}_{2}\right]^{3+}$ & $45.93^{\mathrm{d}}$ & -18 & 47.86 \\
$\mathrm{Pu}^{4+}+(\mathrm{DFB})^{3-}+3 \mathrm{H}^{+} \leftrightarrows\left[\mathrm{Pu}(\mathrm{DFB}) \mathrm{H}_{3}\right]^{4+}$ & $46.54^{\mathrm{d}}$ & -12 & 47.82 \\
$\mathrm{Pu}^{4+}+2(\mathrm{DFB})^{3-}+4 \mathrm{H}^{+} \leftrightarrows\left[\mathrm{Pu}(\mathrm{DFB})_{2} \mathrm{H}_{4}\right]^{2+}$ & $84.42^{\mathrm{d}}$ & -34 & 88.06
\end{tabular}

a Thermodynamic equilibrium constants were estimated by extrapolation to $I=0$ of the conditional constants measured at $I=0.1 \mathrm{M}$, by using the Davies equation: $\log \beta^{\circ}{ }_{m l h}=\log \beta_{m l h}-0.107 \Delta z^{2}$.

b $I=0.1 \mathrm{M} \mathrm{KNO}_{3}, T=298.2 \mathrm{~K}$, this work.

c $I=0.1 \mathrm{M} \mathrm{KCl}, T=298.2 \mathrm{~K}$, Evers et al. (1989).

d $I=0.1 \mathrm{M} \mathrm{NaNO}_{3}, T=298.2 \mathrm{~K}$, Boukhalfa et al. (2007). These authors did not report, nor took into account the first protonation constant of $\mathrm{DFB}^{3-}\left(K_{011}\right)$. The tabulated $\log \beta_{m l h}$ value was estimated by assuming $\log K_{011}=$ 11.06 . 


\section{Table 3}

Conditional $\left(\beta_{m l h}\right)$ and thermodynamic $\left(\beta^{\circ}\right.$ mlh $)$ protonation and complexation constants for $\left(\mathrm{L}^{\mathrm{Cy}, \mathrm{Pr}}\right)^{2-}$ with with $\mathrm{Fe}^{3+}$ and $\mathrm{UO}_{2}^{2+}$.

\begin{tabular}{|c|c|c|c|}
\hline Reaction & $\log \beta_{m l h}{ }^{\mathrm{b}}$ & $\Delta z^{2}$ & $\log \beta^{\circ}{ }_{m l h}$ \\
\hline$\left(\mathrm{L}^{\mathrm{Cy}, \mathrm{Pr}}\right)^{2-}+\mathrm{H}^{+} \leftrightarrows\left(\mathrm{L}^{\mathrm{Cy}, \mathrm{Pr}}\right) \mathrm{H}^{-}$ & $9.39(1)$ & -4 & 9.82 \\
\hline$\left(\mathrm{L}^{\mathrm{Cy}, \mathrm{Pr}}\right)^{2-}+2 \mathrm{H}^{+} \leftrightarrows\left(\mathrm{L}^{\mathrm{Cy}, \mathrm{Pr}}\right) \mathrm{H}_{2}$ & 17.81(1) & -6 & 18.45 \\
\hline $\mathrm{Fe}^{3+}+\left(\mathrm{L}^{\mathrm{Cy}, \mathrm{Pr}}\right)^{2-} \leftrightarrows\left[\mathrm{Fe}\left(\mathrm{L}^{\mathrm{Cy}, \mathrm{Pr}}\right)\right]^{+}$ & $22.33(5)$ & -12 & 23.61 \\
\hline $\mathrm{Fe}^{3+}+\left(\mathrm{L}^{\mathrm{Cy}, \mathrm{Pr}}\right)^{2-}+\mathrm{H}_{2} \mathrm{O} \leftrightarrows\left[\mathrm{Fe}\left(\mathrm{L}^{\mathrm{Cy}, \mathrm{Pr}}\right) \mathrm{OH}\right]+\mathrm{H}^{+}$ & $16.13(2)$ & -12 & 17.41 \\
\hline $\mathrm{Fe}^{3+}+\left(\mathrm{L}^{\mathrm{Cy}, \mathrm{Pr}}\right)^{2-}+2 \mathrm{H}_{2} \mathrm{O} \leftrightarrows\left[\mathrm{Fe}\left(\mathrm{L}^{\mathrm{Cy}, \mathrm{Pr}}\right)(\mathrm{OH})_{2}\right]^{-}+2 \mathrm{H}^{+}$ & $6.19(4)$ & -10 & 7.26 \\
\hline $\mathrm{Fe}^{3+}+2\left(\mathrm{~L}^{\mathrm{Cy}, \mathrm{Pr}}\right)^{2-}+\mathrm{H}^{+} \leftrightarrows\left[\mathrm{Fe}\left(\mathrm{L}^{\mathrm{Cy}, \mathrm{Pr}}\right)_{2} \mathrm{H}\right]$ & $39.89(6)$ & -18 & 41.82 \\
\hline $2 \mathrm{Fe}^{3+}+3\left(\mathrm{~L}^{\mathrm{Cy}, \mathrm{Pr}}\right)^{2-} \leftrightarrows\left[\mathrm{Fe}_{2}\left(\mathrm{~L}^{\mathrm{Cy}, \mathrm{Pr}}\right)_{3}\right]$ & $60.28(1)$ & -30 & 63.49 \\
\hline $\mathrm{UO}_{2}^{2+}+\left(\mathrm{L}^{\mathrm{Cy}, \mathrm{Pr}}\right)^{2-} \leftrightarrows\left[\mathrm{UO}_{2}\left(\mathrm{~L}^{\mathrm{Cy}, \mathrm{Pr}}\right)\right]$ & $13.55(1)$ & -8 & 14.41 \\
\hline $\mathrm{UO}_{2}^{2+}+\left(\mathrm{L}^{\mathrm{Cy}, \mathrm{Pr}}\right)^{2-}+\mathrm{H}^{+} \leftrightarrows\left[\mathrm{UO}_{2}\left(\mathrm{~L}^{\mathrm{Cy}, \mathrm{Pr}}\right) \mathrm{H}\right]^{+}$ & $17.41(1)$ & -8 & 18.26 \\
\hline $\mathrm{UO}_{2}{ }^{2+}+\left(\mathrm{L}^{\mathrm{Cy}, \mathrm{Pr}}\right)^{2-}+\mathrm{H}_{2} \mathrm{O} \leftrightarrows\left[\mathrm{UO}_{2}\left(\mathrm{~L}^{\mathrm{Cy}, \mathrm{Pr}}\right) \mathrm{OH}\right]^{-}+\mathrm{H}^{+}$ & $6.64(1)$ & -6 & 7.29 \\
\hline $\mathrm{UO}_{2}^{2+}+2\left(\mathrm{~L}^{\mathrm{Cy}, \mathrm{Pr}}\right)^{2-} \leftrightarrows\left[\mathrm{UO}_{2}\left(\mathrm{~L}^{\mathrm{Cy}, \mathrm{Pr}}\right)_{2}\right]^{2-}$ & $17.88(8)$ & -8 & 18.74 \\
\hline $\mathrm{UO}_{2}{ }^{2+}+2\left(\mathrm{~L}^{\mathrm{Cy}, \mathrm{Pr}}\right)^{2-}+\mathrm{H}^{+} \leftrightarrows\left[\mathrm{UO}_{2}\left(\mathrm{~L}^{\mathrm{Cy}, \mathrm{Pr}}\right)_{2} \mathrm{H}\right]^{-}$ & $26.61(4)$ & -12 & 27.89 \\
\hline
\end{tabular}

a Thermodynamic equilibrium constants were estimated by extrapolation to $I=0$ of the conditional constants measured at $I=0.1 \mathrm{M}$ by using the Davies equation: $\log \beta_{m l h}^{\circ}=\log \beta_{m l h}-0.107 \Delta z^{2}$.

b $I=0.1 \mathrm{M} \mathrm{KNO}_{3}, T=298.2 \mathrm{~K}$, this work.

Acid-base properties of both ligands were evaluated by glass-electrode potentiometry. While $\mathrm{DFB}^{3-}$ possesses four protonation sites $(h=4)$, namely three hydroxamate and one terminal primary amine groups (Fig. S4), $\left(\mathrm{L}^{\mathrm{Cy}, \mathrm{Pr}}\right)^{2-}$ behaves as a weak diprotic base $(h=2)$ in the $\mathrm{p}[\mathrm{H}]$ range 2-12 (Fig. S7). The values of the experimental stepwise protonation constants (Eqs. (9) and (10)) measured herein were $\log K_{01 h}=11.06(3), 9.69(3), 8.95(2), 8.36(2)$ for $\mathrm{DFB}^{3-}$ ( $h=1-4$, average of 4 replicates, standard deviations are given in parentheses) and log $K_{01 h}=9.39(1), 8.42(1)$ for $\left(\mathrm{L}^{\mathrm{Cy}, \mathrm{Pr}}\right)^{2-}(h=1-2$, average of 3 replicates $)$.

$$
\mathrm{LH}_{h-1}+\mathrm{H} \leftrightarrows \mathrm{LH}_{h}
$$

$$
K_{01 h}=\frac{\left[\mathrm{LH}_{h}\right]}{\left[\mathrm{LH}_{h-1}\right][\mathrm{H}]} \quad \text { with } \quad \beta_{01 h}=\prod_{i=1}^{h} K_{01 i}
$$

For $\mathrm{DFB}^{3-}, K_{011}$ is associated to the protonation of the dangling primary amino group, which occurs at the upper $\mathrm{p}[\mathrm{H}]$ range accessible to a glass electrode. Thus, the measured value 
$\left(\log K_{011}=11.06\right)$ is somewhat less reliable as compared to the three other constants, but is in rather good agreement with the literature data $\left(\log K_{011}=10.84(5)-11.0(2)\right)$ at the same ionic strength (Hernlem et al., 1996; Martell et al., 2004; Duckworth and Sposito, 2005). Logarithmic values for the three constants pertaining to the protonation of the hydroxamate groups are comparable to those previously determined by the aforementioned authors. As far as $\left(\mathrm{L}^{\mathrm{Cy}} \mathrm{Pr}\right)^{2-}$ is concerned, $\log K_{011}=9.39(1)$ and $\log K_{012}=8.42(1)$ values fall in the expected range for linear dihydroxamate binders (Barclay et al., 1984; Farkas et al., 2002, 2004) and are almost identical to those of the conjugated base of RA $\left(\log K_{011}=9.44(3)\right.$ and $\log K_{012}=8.49(3)$; Barclay et al., 1984). The average value $\left(\log K_{\mathrm{av}}=8.93\right)$ is almost identical to the mean protonation constant calculated for the hydroxamate groups of $\mathrm{DFB}^{3-}\left(\log K_{\mathrm{av}}=9.00(5)\right)$, while it is about $0.3 \log$ unit higher than the protonation constant of the model compound, $\mathrm{N}$ methylacetohydroxamate $\left(\mathrm{NMA}^{-}, \log K_{011}=8.68(3)\right)$, that was measured under identical conditions (Sornosa-Ten at al., 2018).

The $\mathrm{UO}_{2}{ }^{2+}$ speciation in the presence of $\mathrm{DFB}^{3-}$ (Fig. S4 and Fig. S5) and $\left(\mathrm{L}^{\mathrm{Cy}, \mathrm{Pr}}\right)^{2-}$ (Fig. S7 and Fig. S8) was conveniently investigated as a function of $\mathrm{p}[\mathrm{H}]$ by potentiometry alone or coupled to absorption spectrophotometry in the visible range, following the procedures previously reported by Sornosa-Ten at al. (2018). The red-orange color taken by the complexes in solution arises from charge transfer bands that undergo simultaneously a progressive hyperchromic effect and hypsochromic shift upon raising the $\mathrm{p}[\mathrm{H}]$. The $\mathrm{p}[\mathrm{H}]$ for the $\mathrm{UO}_{2}(\mathrm{OH})_{2}$ precipitation onset depends on the metal-over-ligand ratio (ca. 7.5 for a 1:1 or 9.0 for a 1:2 ratio in the case of $\mathrm{DFB}^{3-}$ for example). Kinetic monitoring established that equilibrium was reached within the mixing time, while the absorbance changes as a function of $\mathrm{p}[\mathrm{H}]$ for the forward and backward titrations were found to be reversible. The simultaneous fitting of the potentiometric and spectrophotometric data sets with the Hyperquad 2006 program (Gans et al., 1996) enabled to propose the best speciation model, to refine the apparent global stability constants, and to compute the absorption spectrum for each species. The reliability of the entire non-linear least squares minimization procedure could be ascertained by the overall standard deviation, the visual inspection of the plot of residues, and the physical meaning of the calculated absorption spectra. In that respect, the spectrum returned by Hyperquad for free uranyl cation prevailing at low $\mathrm{p}[\mathrm{H}]$ was of particular value, as it reproduced well the expected vibronic structure, band position and intensity $\left(\lambda_{\max }=415 \mathrm{~nm}, \varepsilon=9 \mathrm{M}^{-1} \mathrm{~cm}^{-1}\right)$. This excellent match provides high confidence in all refined parameters. 
For $\mathrm{DFB}^{3-}$, three mononuclear species of $\left[\mathrm{UO}_{2}(\mathrm{DFB}) \mathrm{H}_{h}\right]^{(h-1)+}$ general formulae with $h=$ 1-3 were sufficient to interpret all titration data collected for a $10^{-3} \mathrm{M}$ total $\mathrm{U}$ concentration, an equimolar amount (Fig. S5) or a 2-fold excess of ligand over metal. The corresponding $\log \beta_{11 h}$ values refined simultaneously for six experiments were 27.5(1), 33.8(1), and 37.5(1) for $h=1-$ 3, respectively (calculated absorption spectra are displayed in Fig. S6; spectral properties are reported in Table $\mathrm{S} 1)$. For the dihydroxamate ligand $\left(\mathrm{L}^{\mathrm{Cy}}, \mathrm{Pr}\right)^{2-}$, a more complex speciation model had to be considered in order to reproduce properly the potentiometric titration curves (Fig. S7) and the spectral changes recorded for 1:1 and 1:2 metal/ligand concentration ratios (Fig. S8). Eleven individual data sets were merged and refined together with Hyperquad. The best model returning reasonable absorption spectra for each species included five complexes (Fig. S9), namely $\left[\mathrm{UO}_{2}\left(\mathrm{~L}^{\mathrm{Cy}, \mathrm{Pr}}\right)\right]\left(\log \beta_{110}=13.55(1)\right),\left[\mathrm{UO}_{2}\left(\mathrm{~L}^{\mathrm{Cy}, \mathrm{Pr}}\right) \mathrm{H}\right]^{+}\left(\log \beta_{111}=17.41(1)\right)$, $\left[\mathrm{UO}_{2}\left(\mathrm{~L}^{\mathrm{Cy}, \mathrm{Pr}}\right) \mathrm{OH}\right]^{-}\left(\log \beta_{11-1}=6.64(1)\right),\left[\mathrm{UO}_{2}\left(\mathrm{~L}^{\mathrm{Cy}, \mathrm{Pr}}\right)_{2}\right]^{2-}\left(\log \beta_{120}=17.88(8)\right)$, and $\left[\mathrm{UO}_{2}\left(\mathrm{~L}^{\mathrm{Cy}, \mathrm{Pr}}\right)_{2} \mathrm{H}\right]^{-}\left(\log \beta_{121}=26.61(4)\right)($ Table 3$)$.

Iron(III) uptake by the dihydroxamate ligand $\left(\mathrm{L}^{\mathrm{Cy}, \mathrm{Pr}}\right)^{2-}$ was investigated by combining spectrophotometric and potentiometric titrations. As for $\mathrm{DFB}^{3-}$ and other related dihydroxamate chelators, complex formation starts at $\mathrm{p}[\mathrm{H}]$ values well below 2 . Therefore, a competition experiment with $\mathrm{Na}_{2} \mathrm{H}_{2}$ EDTA was performed in triplicate at $\mathrm{p}[\mathrm{H}]=2.8$ by using a $0.05 \mathrm{M}$ chloroacetic acid/chloroacetate buffer solution, while adjusting the total ionic strength to $I=$ $0.1 \mathrm{M}$ with $\mathrm{KNO}_{3}$ (Fig. S10a). The ligand-to-metal charge transfer (LMCT) absorption band of an equimolar mixture of $\mathrm{Fe}^{3+}$ and ligand $\left(2 \times 10^{-4} \mathrm{M}\right)$ at $\mathrm{p}[\mathrm{H}] 2.8$ in the absence of competitor showed a maximum at $470 \mathrm{~nm}\left(\varepsilon=2000 \mathrm{M}^{-1} \mathrm{~cm}^{-1}\right)$. Both the wavelength and extinction coefficient are characteristic of a dihydroxamato environment (Farkas et al., 2004), thus suggesting the predominance of the bischelated $\left[\mathrm{Fe}\left(\mathrm{L}^{\mathrm{Cy}} \mathrm{Pr}\right)\right]^{+}$species in solution. Upon addition of up to 2.5 equiv. of $\mathrm{Na}_{2} \mathrm{H}_{2}$ EDTA dissolved in the same buffer solution, the LMCT band fully vanished at the expense of the spectrum of $[\mathrm{Fe}(\mathrm{EDTA})]^{-}$with an isosbestic point at $371 \mathrm{~nm}$, suggesting that only two absorbing species, $\left[\mathrm{Fe}\left(\mathrm{L}^{\mathrm{Cy}, \mathrm{Pr}}\right)\right]^{+}$and $[\mathrm{Fe}(\mathrm{EDTA})]^{-}$, were in equilibrium without formation of ternary complexes (Fig. S10b). Numerical analysis of the spectral changes allowed us to calculate the apparent stability constant for $\left[\mathrm{Fe}\left(\mathrm{L}^{\mathrm{Cy}, \mathrm{Pr}}\right)\right]^{+}\left(\log \beta_{110}=22.33(5)\right)$ upon fixing the equilibrium constants for the $\mathrm{Fe}^{3+} / \mathrm{EDTA}^{4-}$ system (Martell et al., 2004) during the refinement. The returned $\log \beta_{110}$ value agrees well with those found in the literature for a variety of related linear dihydroxamate ligands (Barclay et al., 1984; Nguyen-van-Duong et al., 2001; Farkas et al., 1999, 2002, 2004), including RA ( $\log \beta_{110}=21.55(8)$; Carrano et al., 1979). 
The iron binding properties of the dihydroxamate chelator were further examined over a wide $\mathrm{p}[\mathrm{H}]$ range $(2-11)$ for $1: 1,1: 2,1: 3$, and 2:3 metal-over-ligand concentration ratios by potentiometry (Fig. S11) and by visible absorption spectrophotometry for the 1:1 and 2:3 ratios (Fig. S12). In all conditions, the solutions around $\mathrm{p}[\mathrm{H}] 2$ were dark red with an absorption maximum at $470 \mathrm{~nm}$, characteristic of the dihydroxamato binding mode. For an equimolar mixture of $\mathrm{Fe}^{3+}$ and $\left(\mathrm{L}^{\mathrm{Cy}, \mathrm{Pr}}\right) \mathrm{H}_{2}\left(2 \times 10^{-3} \mathrm{M}\right)$, the potentiometric titration curve showed a single inflection point corresponding to the neutralization of two equivalents of protons released during the formation at $\mathrm{p}[\mathrm{H}] \approx 2$ of the $\left[\mathrm{Fe}\left(\mathrm{L}^{\mathrm{Cy}}, \mathrm{Pr}\right)\right]^{+}$complex, followed by precipitation of $\mathrm{Fe}(\mathrm{OH})_{3}$ above $\mathrm{p}[\mathrm{H}] \approx 5$. The yellow solid phase was identified by absorption spectrophotometry after recovering it by centrifugation, water washing, and dissolution in diluted $\mathrm{HNO}_{3}$. Titration curves for the $1: 2$ and 1:3 ratios showed an inflection point at $n_{\mathrm{OH}} / n_{\mathrm{L}}=$ 1.5 and 1 equiv. of added base per ligand, respectively, followed by a buffer region until the beginning of $\mathrm{Fe}(\mathrm{OH})_{3}$ precipitation above $\mathrm{p}[\mathrm{H}] \approx 10$, while the inflection point was found at $n_{\mathrm{OH}} / n_{\mathrm{L}}=2$ equiv. for the $2: 3$ molar concentration ratio. Noteworthy, the red color progressively changed to orange upon reaching the equivalence point and became yellowish at higher $\mathrm{p}[\mathrm{H}]$. Data processing with the Hyperquad program could be best achieved by assuming a chemical model counting five complexed species, namely $\left[\mathrm{Fe}\left(\mathrm{L}^{\mathrm{Cy}, \mathrm{Pr}}\right)\right]^{+}, \quad\left[\mathrm{Fe}\left(\mathrm{L}^{\mathrm{Cy}, \mathrm{Pr}}\right) \mathrm{OH}\right]$, $\left[\mathrm{Fe}\left(\mathrm{L}^{\mathrm{Cy}, \mathrm{Pr}}\right)(\mathrm{OH})_{2}\right]^{-},\left[\mathrm{Fe}\left(\mathrm{L}^{\mathrm{Cy}, \mathrm{Pr}}\right)_{2} \mathrm{H}\right]$, and $\left[\mathrm{Fe}_{2}\left(\mathrm{~L}^{\mathrm{Cy}, \mathrm{Pr}}\right)_{3}\right]$, although the three last could not be detected in equimolar conditions. The hydrolysis constants of $\mathrm{Fe}^{3+}$ at $I=0.1 \mathrm{M}$ taken from Baes and Mesmer (1976) together with the protonation constants of $\left(\mathrm{L}^{\mathrm{Cy}, \mathrm{Pr}}\right)^{2-}$ were treated as fixed parameters. The stability constants obtained for a global fit were in the range expected for the mononuclear hydroxo species $\left[\mathrm{Fe}\left(\mathrm{L}^{\mathrm{Cy}, \mathrm{Pr}}\right) \mathrm{OH}\right]\left(\log \beta_{11-1}=16.78(2)\right)$ and $\left[\mathrm{Fe}\left(\mathrm{L}^{\mathrm{Cy}, \mathrm{Pr}}\right)(\mathrm{OH})_{2}\right]^{-}(\log$ $\left.\beta_{11-1}=6.31(2)\right)$, and the dinuclear $\left[\mathrm{Fe}_{2}\left(\mathrm{~L}^{\mathrm{Cy}, \mathrm{Pr}}\right)_{3}\right]$ complex $\left(\log \beta_{11-1}=60.36(4)\right)$ according to the work of Farkas et al. (2002, 2004), although these authors did not mention the formation of a complex having the $\left[\mathrm{Fe}(\mathrm{L})_{2} \mathrm{H}\right]$ stoichiometry.

Therefore, we performed additional spectrophotometric titrations at 10-fold lower concentration levels $\left(2 \times 10^{-4} \mathrm{M}\right)$ for 1:1 and 2:3 metal/ligand concentration ratios to ascertain the chemical model and to identify the chemical environment around the iron center of each species by relying on the wavelength and extinction coefficient at the maximum of the ligandto-metal charge transfer band. Typical absorption spectra collected during the titrations are displayed in Fig. S12. In all cases, the LMCT band maximum progressively shifts from $470 \mathrm{~nm}$ down to $380 \mathrm{~nm}$ upon raising the $\mathrm{p}[\mathrm{H}]$ with well-defined buffer zones, but the band intensity variations depend on the metal-over-ligand concentration ratio. For 1:1 conditions, a continuous 
hypochromic effect was observed, while for a 2:3 ratio the band initially centered at $470 \mathrm{~nm}$ shifted first to $425 \mathrm{~nm}$ at $\mathrm{p}[\mathrm{H}] \approx 6$ with a concomitant enhancement of the intensity by a factor of ca. 1.3. However, above $\mathrm{p}[\mathrm{H}] 8$ the hypsochromic displacement was accompanied by a $\sim 40 \%$ decrease of the absorptivity until reaching the precipitation onset at $\mathrm{p}[\mathrm{H}] \approx 11.7\left(\lambda_{\max }=380\right.$ $\mathrm{nm}$ ). A global fit with the HypSpec program (Protonic Software) returned the conditional equilibrium constants summarized in Table 3, which were in good agreement with the values derived by potentiometry. Accordingly, $\left[\mathrm{Fe}\left(\mathrm{L}^{\mathrm{Cy}, \mathrm{Pr}}\right)\right]^{+}$is more stable than $[\mathrm{Fe}(\mathrm{RA})]^{+}$by about 0.8 $\log$ unit, while $\left[\mathrm{Fe}_{2}\left(\mathrm{~L}^{\mathrm{Cy}, \mathrm{Pr}}\right)_{3}\right]$ is nearly 100 times less stable than $\left[\mathrm{Fe}_{2}(\mathrm{RA})_{3}\right]$ (Carrano et al., 1979). The calculated electronic absorption spectra of the five iron(III) complexes formed with $\left(\mathrm{L}^{\mathrm{Cy}}, \mathrm{Pr}\right)^{2-}$ are shown in Fig. S13. While a trishydroxamato binding mode for both hexacoordinated iron center of $\left[\mathrm{Fe}_{2}\left(\mathrm{~L}^{\mathrm{Cy}, \mathrm{Pr}}\right)_{3}\right]$ was anticipated based on the stoichiometry and the calculated spectral features $\left(\lambda_{\max }=421 \mathrm{~nm}, \varepsilon_{\max }=5350 \mathrm{M}^{-1} \mathrm{~cm}^{-1}\right)$, the same environment could be ascertained for $\left[\mathrm{Fe}\left(\mathrm{L}^{\mathrm{Cy}, \mathrm{Pr}}\right)_{2} \mathrm{H}\right]\left(\lambda_{\max }=425 \mathrm{~nm}, \varepsilon_{\max }=3480 \mathrm{M}^{-1} \mathrm{~cm}^{-1}\right)$. The calculated spectrum of $\left[\mathrm{Fe}\left(\mathrm{L}^{\mathrm{Cy}, \mathrm{Pr}}\right)\right]^{+}\left(\lambda_{\max }=470 \mathrm{~nm}, \varepsilon_{\max }=2070 \mathrm{M}^{-1} \mathrm{~cm}^{-1}\right)$ supports a bischelated dihydroxamato structure, while the stepwise displacement of both water molecules from the first coordination shell by $\mathrm{OH}^{-}$produces both hypsochromic and hypochromic shifts, with $\lambda_{\max }$ $=413 \mathrm{~nm}, \varepsilon_{\max }=1900 \mathrm{M}^{-1} \mathrm{~cm}^{-1}$ for $\left[\mathrm{Fe}\left(\mathrm{L}^{\mathrm{Cy}, \mathrm{Pr}}\right) \mathrm{OH}\right]$ and $\lambda_{\max }=372 \mathrm{~nm}, \varepsilon_{\max }=1710 \mathrm{M}^{-1} \mathrm{~cm}^{-1}$ for $\left[\mathrm{Fe}\left(\mathrm{L}^{\mathrm{Cy}, \mathrm{Pr}}\right)(\mathrm{OH})_{2}\right]^{-}$.

\subsection{Extraction of $U$ and Pu from soils by the different chelators}

Next, the efficiency of both DFB and $\mathrm{L}\left({ }^{\mathrm{Cy}}, \mathrm{Pr}\right) \mathrm{H}_{2}$ siderochelates to extract $\mathrm{U}$ or $\mathrm{Pu}$ from four different soils and to transfer the solubilized radionuclides into the water phase contained in stirred batch reactors was assessed over a 7-day period. The aim of these experiments was to compare the results obtained for both hydroxamic acids with those found for pure water and citrate. The latter is an ubiquitous carboxylic chelator found in soils, as a root exuded involved in the assimilation of metal cations by plants. Fig. 2 shows the $\mathrm{U}$ and $\mathrm{Pu}$ concentrations in the supernatant for different extraction times and media. For an easier comparison of the results obtained for pure water, DFB and $\mathrm{L}\left({ }^{\mathrm{Cy}}, \mathrm{Pr}\right) \mathrm{H}_{2}$ in the low $\mathrm{U}$ concentration range, a similar graph omitting the data for citrate is included in Fig. S14. 


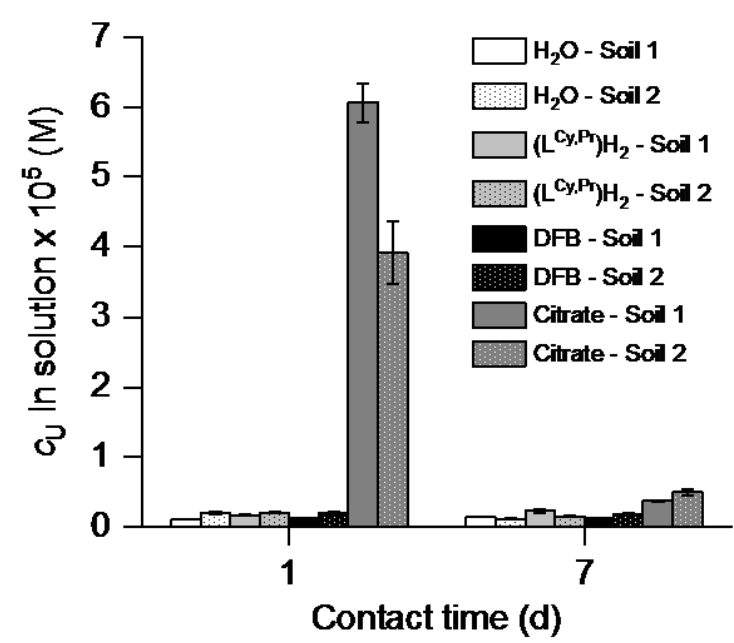

(a)

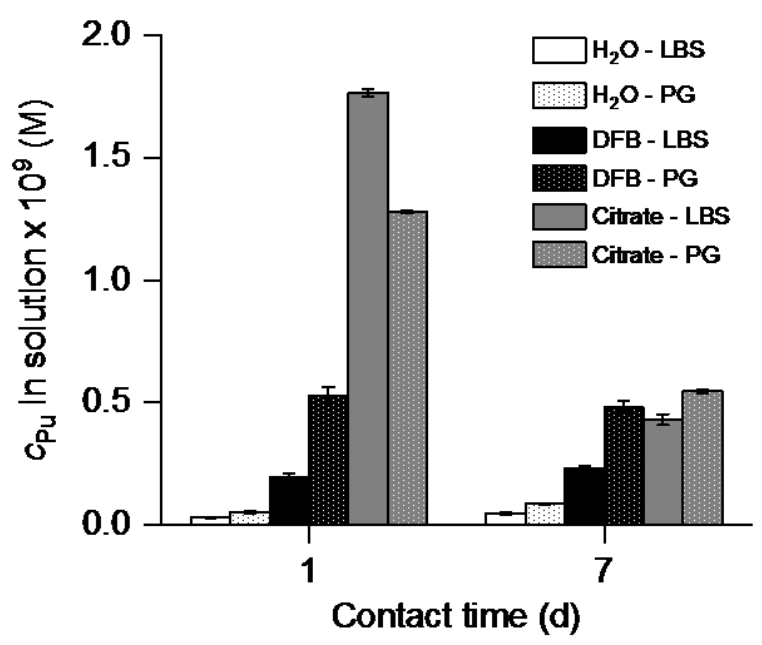

(b)

Fig. 2. Amount of uranium (a) and plutonium (b) recovered in solution after 1 and 7 days of contact between the tested soils and the different extraction media (pure water, $10^{-3} \mathrm{M}$ $\left(\mathrm{L}^{\mathrm{Cy}, \mathrm{Pr}}\right) \mathrm{H}_{2}$, DFB, or sodium citrate solution) in sealed batch reactors. Data correspond to the average of $3(\mathrm{U})$ or $2(\mathrm{Pu})$ independent measurements; error bars represent standard deviations.

Pure water extracted only very low amounts of both $\mathrm{U}$ and $\mathrm{Pu}$, whatever the contact time. For soils 1 and 2, the $\mathrm{U}$ extraction yields after 1 or 7 days were nearly identical, as they amounted about $0.7 \%$ of the total $\mathrm{U}$ present, corresponding to a liquid-solid distribution coefficient $R_{\mathrm{d}}$ of $1495 \pm 24$ and $1380 \pm 55 \mathrm{~L} \mathrm{~kg}^{-1}$ for soils 1 and 2, respectively. In contrast, the amount of $\mathrm{Pu}$ recovered in the aqueous phase doubled when the contact time increased from 1 to 7 days. Recovered amounts ranged from $0.77 \pm 0.05 \%$ at day 1 to $1.2 \pm 0.1 \%$ at day 7 for the LBS soil and from $1.2 \pm 0.1 \%$ to $2.14 \pm 0.05 \%$ for the PG soil. These yields correspond to $R_{\mathrm{d}}$ values of $798 \pm 75$ and $442 \pm 14 \mathrm{~L} \mathrm{~kg}^{-1}$ at day 7 for LBS and PG soils, respectively.

In all cases, citrate was by far the most efficient extracting agent for short contact times. After 1 day, the $U$ concentrations in solution were 55 and 20-fold higher than those obtained with pure water as extraction medium for soils 1 and 2, respectively, corresponding to an extraction of $29 \pm 2 \%$ and $24 \pm 3 \%$ of the total $U$. The same increase was recorded for the concentration of soluble Pu (55 and 25-fold for LBS and PG soils, respectively), corresponding to an extraction of $45.1 \pm 0.3 \%$ and $32.1 \pm 0.2 \%$ of the total Pu in LBS and PG soils, respectively, after 1 day. However, the efficiency of citrate decreased drastically for longer contact times. After 7 days, the amount extracted dropped down to $1.78 \pm 0.04 \%$ and $3.1 \pm$ $0.3 \%$ for $\mathrm{U}$ from soils 1 and 2 , respectively, and to $10.8 \pm 0.5 \%$ and $14.1 \pm 0.2 \%$ for Pu from 
soils LBS and PG, respectively. Remarkably, the extraction yields for $\mathrm{U}$ after 7 days of contact approached those found for pure water.

The efficiency of DFB to extract $\mathrm{U}$ and Pu differed for both considered radionuclides. For $\mathrm{U}$, the yields were comparable to those found for water, whatever the contact time within a week. After 7 days, the amounts of extracted $U$ were $0.59 \pm 0.01 \%$ and $1.1 \pm 0.1 \%$ of the total $\mathrm{U}$ initially present in soils 1 and 2, respectively. For Pu, DFB showed a significantly higher extraction efficiency than water, whatever the contact time and the soil sample. For short contact times ( 1 day), the yield of Pu extraction by DFB $(5.0 \pm 0.3 \%$ and $13.0 \pm 0.8 \%$ for LBS and PG soils, respectively) remained however significantly lower than those obtained with citrate. But unlike citrate, the amount of Pu extracted by DFB was not impacted by the contact time. Therefore, after 7 days DFB extracted nearly the same amount of Pu than citrate in both soils (5.8 $\pm 0.3 \%$ and $12.2 \pm 0.6 \%$ in LBS and PG soils, respectively). As for water and for both contact times, DFB extracted more Pu from the PG than from the LBS soil.

Finally, extraction by $\left(\mathrm{L}^{\mathrm{Cy}}, \mathrm{Pr}\right) \mathrm{H}_{2}$ was tested only for $\mathrm{U}$ in natural soils. A higher efficiency of extraction with time was observed for soil 1 but not for soil 2, for which the yield of extraction was not affected by time. After 7 days of contact, the amount of recovered $U$ by $\left(\mathrm{L}^{\mathrm{Cy}, \mathrm{Pr}}\right) \mathrm{H}_{2}$ was about $40 \%$ higher than the one recovered by water or DFB from soil 1. For soil 2 , the amount recovered was $20 \%$ higher than the one extracted by water, but it was of the same order of magnitude than the one extracted by DFB.

\subsection{Evolutions of the $\mathrm{pH}$ and of the Fe and extractant concentrations during the experiments}

The $\mathrm{pH}$ of the supernatant in each batch reactor was measured for all extraction times (Fig. S15). For U extraction experiments, the $\mathrm{pH}$ fluctuated between 5.2 for the lowest value (in the presence of DFB at day 1) to 6.3 for the highest value (in the presence of citrate at day 7) for soil 1, and between 4.7 and 6.0 for soil 2. In most cases, an increase in the $\mathrm{pH}$ of the supernatants, not exceeding $0.7 \mathrm{pH}$ unit, was recorded between the first and the seventh day of contact. Addition of DFB or $\left(\mathrm{L}^{\mathrm{Cy}, \mathrm{Pr}}\right) \mathrm{H}_{2}$ decreased the $\mathrm{pH}$ compared to water at short contact times, but this variation was no longer noticeable after 7 days. Addition of citrate led in turn to slight $\mathrm{pH}$ increases (0.6 unit at maximum). The same effect was also recorded for Pu extractions by DFB and citrate from both LBS and PG soils. However, the impact of citrate was more pronounced on these soils, with an increase of $1.5 \mathrm{pH}$ units after 7 days, as compared to water. For all tests, the $\mathrm{pH}$ of the supernatants remained below 7, in accordance with the initial $\mathrm{pH}$ values of the various soil solutions. 
As expected, $\mathrm{U}$ and $\mathrm{Pu}$ extractions were also accompanied by that of $\mathrm{Fe}$. Amounts of $\mathrm{Fe}$ released into the supernatants are presented in Fig. 3 for all experiments. They depend on the nature of the extractants and on the contact time in some instances. Release of Fe in the absence of any extractant was very limited, but the amount increased as a function of contact time. Expressed in percentage of the total Fe content of soils, this amount is similar in the four soils (around $0.11 \%$ at day 7). In both soils 1 and 2, the Fe concentration reached about $9 \times 10^{-5} \mathrm{M}$ after 7 days of contact, corresponding to a 70-fold excess over the amount of released U, while it was only $2 \times 10^{-5} \mathrm{M}$ for the Pu-contaminated LBS and PG soils. Due to the very low amounts of $\mathrm{Pu}$ in our experiments, the Fe level in the soil solutions was 5 orders of magnitude higher than the one of $\mathrm{Pu}$ after 7 days of contact.

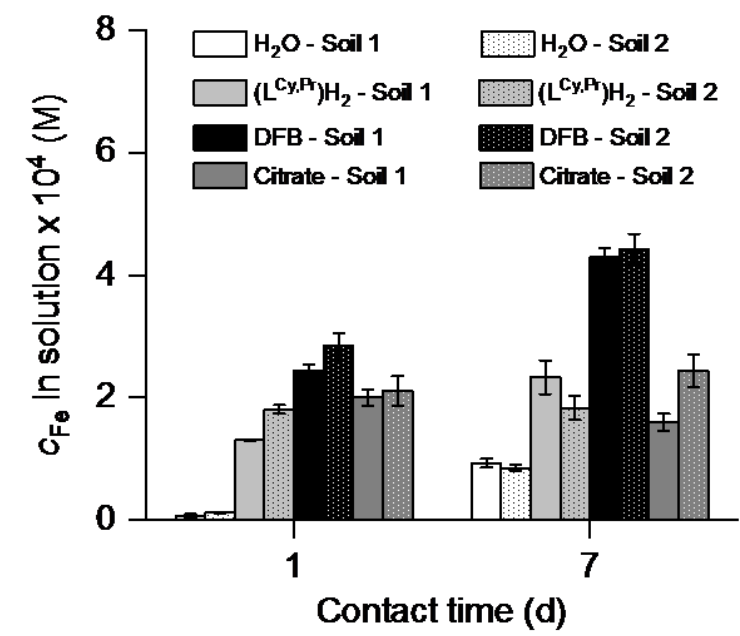

(a)

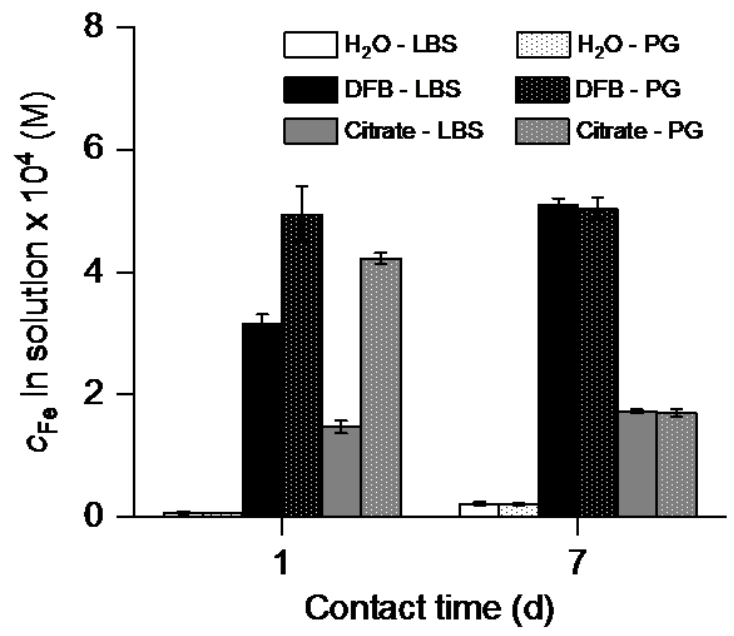

(b)

Fig. 3. Amount of iron recovered in solution after 1 and 7 days of contact between (a) the Uand (b) the Pu-contaminated soils and the different extraction media (pure water, $10^{-3} \mathrm{M}$ $\left(\mathrm{L}^{\mathrm{Cy}, \mathrm{Pr}}\right) \mathrm{H}_{2}$, DFB, or sodium citrate solution) in sealed batch reactors. Data correspond to the average of $3(\mathrm{U})$ or $2(\mathrm{Pu})$ independent measurements; error bars represent standard deviations.

All extractants induced an increase of the Fe concentration in the supernatants. In the presence of citrate and considering the measurement uncertainties, the amounts of Fe released into the solutions were almost the same for both contact times, except for the Pu extraction from the PG soil, where the iron concentration in the supernatants decreased between day 1 and 7 . The amounts of Fe released by soils 1 and 2 were similar, with an average concentration of ca. $2 \times 10^{-4} \mathrm{M}$, corresponding to about $0.2-0.3 \%$ of the total Fe content. Due to the high concentration of $U$ released by citrate, this concentration is only 45 times higher than the one of $U$ at day 7. The amounts of Fe released from LBS and PG soils between day 1 and 7 showed 
different evolutions but converged to the same value after 7 days of contact. In percentage, this value is around $0.7-0.8 \%$ of the total Fe content, which is a bit higher than in soils 1 and 2 . As for water, the Fe concentrations in solution were 5 orders of magnitude higher than the ones of $\mathrm{Pu}$ after 7 days of contact for both soils.

The evolution of the Fe concentration released in the presence of DFB differed from the corresponding changes observed for water and citrate media. Firstly, DFB produced the strongest Fe release in all experiments. Secondly, the amount of solubilized Fe increased as a function of contact time in all conditions. After 7 days of contact, the Fe concentration reached about $4.3 \times 10^{-4}$ and $5 \times 10^{-4} \mathrm{M}$ in $\mathrm{U}$ and $\mathrm{Pu}$ extraction experiments, respectively. These levels are 2 times higher than those reached during citrate extractions. They are 345 and 230 times higher than the $\mathrm{U}$ concentrations released from soils 1 and 2, respectively, and 6 orders of magnitude higher than the ones of Pu. Given the fact that LBS and PG soils have a lower total Fe content than soils 1 and 2, these similar Fe concentrations in solution correspond actually to the release of about $0.55 \%$ of Fe from soils 1 and 2 and more than $2 \%$ from soils LBS and PG.

The Fe leaching during $\mathrm{U}$ extraction with $\left(\mathrm{L}^{\mathrm{Cy}}, \mathrm{Pr}\right) \mathrm{H}_{2}$ followed an intermediate evolution. As in the presence of DFB, the quantity of released Fe increased as a function of contact time, particularly in the case of soil 1. However, it remained very small compared to the levels reached during the extractions performed with DFB: the Fe concentrations after 7 days of contact were slightly lower than the ones obtained after 1 day in the presence of DFB, i.e. (2.3 $\pm 0.3) \times 10^{-4}$ and $(4.4 \pm 0.3) \times 10^{-4} \mathrm{M}$ for soils 1 and 2 , respectively (corresponding to about $0.25-0.3 \%$ of total Fe content of each soil). Consequently, the Fe concentration in solution was around 100 times higher than the one of $U$ for both soils after 7 days.

The total concentrations of the extracting agents in the supernatant solutions (i.e. sum of the free and complexed fractions) were also monitored over time (Fig. S16), except for citrate in the case of $U$ desorption experiments. For soils 1 and 2, the initial DFB and $\left(\mathrm{L}^{\mathrm{Cy}, \mathrm{Pr}}\right) \mathrm{H}_{2}$ concentrations of $10^{-3} \mathrm{M}$ rapidly decreased over time, reaching about $5 \times 10^{-4}$ and $6 \times 10^{-4} \mathrm{M}$ after 1 day, respectively. Then, they remained stable until the $7^{\text {th }}$ day. A similar behavior was also noted for the Pu extraction by DFB, although the levels at which the DFB concentration stabilized after 1 day of contact was a bit higher, with values around $60-65 \%$ of the initial DFB concentration $\left(10^{-3} \mathrm{M}\right)$ for both LBS and PG contaminated soils. Citrate concentrations, which were determined by ion chromatography only for the Pu extraction experiments, decreased 
continuously over one week. After one day, the remaining citrate concentrations in the supernatants represented $80 \%$ of the initial level $\left(10^{-3} \mathrm{M}\right)$, but only $35 \%$ after 7 days of contact.

\subsection{Simulation of the $U, P u$, and Fe speciation in the supernatants in the presence of DFB or $\left(L^{C y, P r}\right) H_{2}$}

As conceived, the batch experiments enabled to determine the total amount of $\mathrm{Fe}, \mathrm{U}$, and $\mathrm{Pu}$ extracted into solution by the different chelators after a given contact time. To go one step further in the data interpretation, the equilibrium constants reported in Table 2 for DFB and Table 3 for $\left(\mathrm{L}^{\mathrm{Cy}, \mathrm{Pr}}\right) \mathrm{H}_{2}$ were implemented in the database of the JChess program, allowing to simulate the $\mathrm{U}, \mathrm{Pu}$, and $\mathrm{Fe}$ species distribution in the presence of either siderochelate. Speciation calculations were performed for the $\mathrm{pH}$ values and the analytical $\mathrm{U}, \mathrm{Pu}, \mathrm{Fe}$, and ligand concentrations measured after a contact time of 7 days. For the $\mathrm{U}$ experiments involving the natural soils 1 and 2, the concentrations of the major cations and anions in the supernatants of the batch reactor tests were taken from previous experiments done with the same soils and for the same soil/volume ratio (Brédoire, 2012). In the case of the Pu-contaminated LBS and PG soils, these data were lacking; thus the simulations were limited to the $\mathrm{Pu}-\mathrm{Fe}-\mathrm{DFB}$ system. Fe was considered as present in the +III oxidation state, as usually done by other authors in such cases (Lofts et al., 2015). The chemical input data used to perform the simulation can be found in Table S2. For all simulations, $\mathrm{DFB}^{3-}$ or $\left(\mathrm{L}^{\mathrm{Cy}, \mathrm{Pr}}\right)^{2-}$ was assumed to react only with $\mathrm{H}^{+}$, $\mathrm{UO}_{2}{ }^{2+} / \mathrm{Pu}^{4+}$, and $\mathrm{Fe}^{3+}$. The thermodynamic stability constants $\left(\beta^{\circ}{ }_{m l h}\right)$ used for the calculations are the ones determined in this study, completed with data from literature when necessary. They are summarized in Table $2\left(\mathrm{DFB}^{3-}\right)$ and Table $3\left(\left(\mathrm{~L}^{\mathrm{Cy}, \mathrm{Pr}}\right)^{2-}\right)$.

The results of the speciation calculations confirmed that $U$ and Fe were mainly complexed by the siderochelates in the supernatant solutions. In the presence of DFB, $U$ was predicted to be chelated by the siderophore at more than $99 \%$, with $\left[\mathrm{UO}_{2}(\mathrm{DFB}) \mathrm{H}_{2}\right]^{+},\left[\mathrm{UO}_{2}(\mathrm{DFB}) \mathrm{H}\right]$, and $\left[\mathrm{UO}_{2}(\mathrm{DFB}) \mathrm{H}_{3}\right]^{2+}$ representing 80,19 , and $0.5 \%$ of the total $\mathrm{U}$ in solution when brought into contact with soil 1 . For the soil 2 solution, the molar fractions were 88,11 , and $1 \%$, respectively. In both cases, soluble Fe was predicted to be entirely complexed by $\mathrm{DFB}^{3-}$, in the form of the trishydroxamato $[\mathrm{Fe}(\mathrm{DFB}) \mathrm{H}]^{+}$complex, in which the dangling $N$-terminal primary amino group is protonated. In these conditions, free DFB in solution (i.e. DFB uncomplexed to $\mathrm{Fe}^{3+}$ or $\mathrm{UO}_{2}{ }^{2+}$ ) was predicted to be around 17 and $25 \%$ of the total soluble DFB for the soil 1 and soil 2 solutions, respectively. 
Similarly, U was predicted to be nearly fully complexed (>99\%) by the dihydroxamic ligand $\left(\mathrm{L}^{\mathrm{Cy}, \mathrm{Pr}}\right)^{2-}$, the main species prevailing in both soil solutions being the neutral bischelated $\left[\mathrm{UO}_{2}\left(\mathrm{~L}^{\mathrm{Cy}, \mathrm{Pr}}\right)\right]$ complex. Fe was also predicted to be entirely bound to the dihydroxamate chelator, the main complex being $\left[\mathrm{Fe}\left(\mathrm{L}^{\mathrm{Cy}, \mathrm{Pr}}\right)_{2} \mathrm{H}\right](\sim 85$ and $95 \%$ in soil 1 and 2 solutions, respectively). The amount of $\left(\mathrm{L}^{\mathrm{Cy}, \mathrm{Pr}}\right) \mathrm{H}_{2}$ remaining uncomplexed with either $\mathrm{Fe}^{3+}$ or $\mathrm{UO}_{2}{ }^{2+}$ varied from $13.5 \%$ (soil 1) to $42.5 \%$ (soil 2) of the total soluble $\left(\mathrm{L}^{\mathrm{Cy}, \mathrm{Pr}}\right) \mathrm{H}_{2}$ concentration, in accordance with the lower total amount of both $\mathrm{U}$ and Fe extracted into the solution from soil 2 as compared to soil 1 .

Similar trends were predicted for the Pu speciation in the LBS and PG soil supernatants. All $\mathrm{Pu}$ was predicted to be complexed by $\mathrm{DFB}^{3-}$, the main species being $\left[\mathrm{Pu}(\mathrm{DFB})_{2} \mathrm{H}_{4}\right]^{2+}(>$ $98 \%$ of the total $\mathrm{Pu}$ concentration in solution). In both cases and similarly to the U extraction experiments, all Fe was predicted to be complexed by $\mathrm{DFB}^{3-}$ in the form of $[\mathrm{Fe}(\mathrm{DFB}) \mathrm{H}]^{+}$, whereas unbound DFB was about $23 \%$ of the total aqueous siderophore concentration.

\section{Discussion}

Both siderochelates considered herein, $\mathrm{DFB}^{3-}$ and $\left(\mathrm{L}^{\mathrm{Cy}} \mathrm{Pr}\right)^{2-}$, were shown to bind the uranyl cation in aqueous solution over a wide $\mathrm{pH}$ range, preventing the precipitation of $\mathrm{UO}_{2}(\mathrm{OH})_{2}$ in neutral or weakly basic media. Our potentiometric and spectrophotometric studies revealed the formation of various complexes that differ by their protonation state and ligand composition. As a matter of fact, the trihydroxamate siderophore $\mathrm{DFB}^{3-}$, which is widely found in groundwater, produces exclusively complexes of 1:1 M/L stoichiometry, while two molecules of the dihydroxamate ligand $\left(\mathrm{L}^{\mathrm{Cy}, \mathrm{Pr}}\right)^{2-}$ can interact with $\mathrm{UO}_{2}{ }^{2+}$. Although the latter chelator was designed and used herein as an abiotic analog of RA, it should be stressed that to the best of our knowledge no speciation data are available yet for the U(VI)/RA system. To allow direct comparison of the stability constants refined for both ligands and to account for the different protonation states of the complexes, it is convenient to calculate apparent $K_{m l h}^{*}$ binding constants by considering as reacting ligand forms those having the same number of deprotonated binding units (1 or 2). For a bishydroxamato environment, as found in $\left[\mathrm{UO}_{2}\left(\mathrm{~L}^{\mathrm{Cy}}, \mathrm{Pr}\right)\right]$ and $\left[\mathrm{UO}_{2}(\mathrm{DFB}) \mathrm{H}_{2}\right]^{+}$, the ligand species to consider are $\left(\mathrm{L}^{\mathrm{Cy}, \mathrm{Pr}}\right)^{2-}$ and $(\mathrm{DFB}) \mathrm{H}_{2}{ }^{-}$, leading to $\log K^{*}{ }_{110}=13.55$ and $\log K^{*}{ }_{112}=13.1$, respectively. In the case of the monochelated complexes $\left[\mathrm{UO}_{2}\left(\mathrm{~L}^{\mathrm{Cy}, \mathrm{Pr}}\right) \mathrm{H}\right]^{+}$and $\left[\mathrm{UO}_{2}(\mathrm{DFB}) \mathrm{H}_{3}\right]^{2+}$, the $\log K^{*}{ }_{111}=8.1$ and $\log K^{*}{ }_{113}=7.8$ values corresponding to the reaction of uranyl with the single deprotonated ligands $\left(\mathrm{L}^{\mathrm{Cy}, \mathrm{Pr}}\right) \mathrm{H}^{-}$and (DFB) $\mathrm{H}_{3}$, respectively, are quite similar too. Moreover, they compare favorably well also with 
the $\log \beta_{110}$ value of 7.76(1) reported for $\mathrm{NMA}^{-}$(Sornosa-Ten et al., 2018), suggesting that the unbound fragment of each chelator does not significantly affect the binding affinity. It is also noteworthy to compare the $\mathrm{p} K_{\mathrm{a}}$ of each dihydroxamato complex, 6.91 for $\left[\mathrm{UO}_{2}\left(\mathrm{~L}^{\mathrm{Cy}}, \mathrm{Pr}\right)\right]$ and 6.3 for $\left[\mathrm{UO}_{2}(\mathrm{DFB}) \mathrm{H}_{2}\right]^{+}$, which are consistent with the deprotonation of the water molecule present in the coordination sphere of uranyl, affording the $\left[\mathrm{UO}_{2}\left(\mathrm{~L}^{\mathrm{Cy}}, \mathrm{Pr}\right) \mathrm{OH}\right]^{-}$and $\left[\mathrm{UO}_{2}(\mathrm{OH})(\mathrm{DFB}) \mathrm{H}_{2}\right]$ species. Indeed, a much higher $\mathrm{p} K_{\mathrm{a}}$ might be expected for the deprotonation of the dangling hydroxamic acid unit in $\left[\mathrm{UO}_{2}(\mathrm{DFB}) \mathrm{H}_{2}\right]^{+}$, especially if it would not bind to the pentacoordinated metal center (no six coordinated trisbidentate hydroxamato uranyl complexes have been reported yet). All these considerations enable to solve the proton ambiguity related to the exact formulation of the neutral DFB complex as $\left[\mathrm{UO}_{2}(\mathrm{OH})(\mathrm{DFB}) \mathrm{H}_{2}\right]$ rather than $\left[\mathrm{UO}_{2}(\mathrm{DFB}) \mathrm{H}\right]$. Moreover, the large hyperchromic effect associated to its formation further supports that assignment.

With respect to our soil studies, an important parameter to consider is the actinide/iron selectivity factor $S_{\mathrm{An} / \mathrm{Fe}}$, which can be expressed as the ratio of stability constants $\left(S_{\mathrm{An} / \mathrm{Fe}}=\right.$ $\left.K^{*}{ }_{m l h}{ }^{\mathrm{An}} / K^{*}{ }_{m l h}{ }^{\mathrm{Fe}}\right)$, provided both metals form complexes having the same formula. As far as $\mathrm{DFB}^{3-}$ is concerned, the prevailing species around neutrality are the monoprotonated trishydroxamato iron complex $[\mathrm{Fe}(\mathrm{DFB}) \mathrm{H}]^{+}$bearing a $N$-terminal ammonium group and the bishydroxamato $\left[\mathrm{UO}_{2}(\mathrm{OH})(\mathrm{DFB}) \mathrm{H}_{2}\right]$ compound. The corresponding selectivity factor $\left(\mathrm{S}_{\mathrm{U} / \mathrm{Fe}}=\right.$ $K^{*}{ }_{111} \mathrm{U} / K^{*}{ }_{111}{ }^{\mathrm{Fe}} \approx 9 \times 10^{-15}$ at $I=0.1 \mathrm{M}$ ) clearly indicates an exceedingly higher affinity of $(\mathrm{DFB}) \mathrm{H}^{2-}$ for the pseudo-octahedral $\mathrm{Fe}^{3+}$ over the linear $\mathrm{UO}_{2}{ }^{2+}$ cation, which can be attributed in part to the different number of chelate cycles around each metal center $\left(3\right.$ for $\mathrm{Fe}^{3+} v s .2$ in the equatorial plane for $\mathrm{UO}_{2}{ }^{2+}$ ). In addition, the higher Lewis acidity and charge density of trivalent iron with respect to uranyl further contribute to stabilize the ferric complex due to stronger electrostatic interactions. By contrast, $(\mathrm{DFB}) \mathrm{H}^{2-}$ shows a higher affinity for $\mathrm{Pu}^{4+}$ than for $\mathrm{Fe}^{3+}$ $\left(S_{\mathrm{Pu} / \mathrm{Fe}}=2400\right)$. Accordingly, DFB is expected to extract Pu more efficiently than $\mathrm{U}$. As found herein for $\left(\mathrm{L}^{\mathrm{Cy}}, \mathrm{Pr}\right)^{2-}$, the bischelated 1:1 Fe(III) complexes with dihydroxamate chelators are about 8-9 orders of magnitude weaker than those formed with trihydroxamate siderophores like $(\mathrm{DFB}) \mathrm{H}^{2-}$. Hence, the relative affinity for $\mathrm{Fe}^{3+}$ over $\mathrm{UO}_{2}{ }^{2+}$ is less enhanced, the selectivity factor for $\left(\mathrm{L}^{\mathrm{Cy}, \mathrm{Pr}}\right)^{2-}$ being close to $1.7 \times 10^{-9}$ when comparing the stabilities of $\left[\mathrm{UO}_{2}\left(\mathrm{~L}^{\mathrm{Cy}}, \mathrm{Pr}\right)\right]$ and $\left[\mathrm{Fe}\left(\mathrm{L}^{\mathrm{Cy}, \mathrm{Pr}}\right)\right]^{+}$.

The efficiency of DFB and $\left(\mathrm{L}^{\mathrm{Cy}, \mathrm{Pr}}\right) \mathrm{H}_{2}$ to solubilize $\mathrm{U}$ or $\mathrm{Pu}$ was assessed in different contexts and compared to that of water and sodium citrate. The use of two naturally U-rich soils 
on the one hand and of two freshly $\mathrm{Pu}$-contaminated forest soils on the other hand, provided two different scenarios regarding the availability of radionuclides in soils. Although the exact speciation of $U$ within the two natural soils selected in the present work was unknown, Pfeiffer et al. (1994) showed that U was mostly adsorbed on iron oxyhydroxyde. Nevertheless, the presence of fine-grained particles of pitchblende $\left(\mathrm{UO}_{2}\right)$ cannot be excluded, as $\mathrm{UO}_{2}$ veins and related rock falls provide the natural sources of $U$ at the sampled site.

In the case of the freshly Pu-contaminated LBS and PG samples, Pu was expected to be mainly sorbed at the surface of soil particles. Several valence states of Pu can co-exist in soils, but $\mathrm{Pu}(\mathrm{V})$ and $\mathrm{Pu}(\mathrm{VI})$ are the most stable forms at high environmental $\mathrm{pH}$, whereas $\mathrm{Pu}(\mathrm{IV})$ is the predominant oxidation state under mildly oxic and acidic conditions (Choppin, 2003; Kaplan et al., 2007). Moreover, several studies have reported that $\mathrm{Pu}(\mathrm{V})$ or $\mathrm{Pu}(\mathrm{VI})$ adsorbed onto the surface of soil minerals, such as iron or manganese oxyhydroxides, was rapidly reduced to $\mathrm{Pu}$ (IV) (Zhao et al., 2016; Conroy et al., 2017). Therefore, it was assumed that Pu was present mostly in its $+\mathrm{IV}$ oxidation state, although the speciation of the Pu adsorbed on the LBS and PG soils was unknown. Because these two forest soils differed by their $\mathrm{pH}$, as well as their clay and organic matter contents (Table 1), both the nature of the soil particle surfaces involved in $\mathrm{Pu}$ adsorption and the strength of this retention might differ.

Experiments with pure water gave a snapshot of the amount of each radionuclide that can pass in solution to restore the equilibrium between concentrations of U/Pu on solid phases and those in solution. Both elements are known to be poorly mobile in soils and our results confirmed this finding. The amount of $U$ in solution is comparable with the value found by Henner et al. (2018) for the same soils (slightly less than 0.5\%) after an extraction period of 5 days with a mineral plant nutrient solution. It also falls within the ranges observed for a natural Belgian soil (Vandenhove et al., 2014), for samples collected at a waste disposal site in India (Rout et al., 2015), at the Oak Ridge (USA) contaminated area (Zheng and Wan, 2005), and at U mill tailings (Liu et al., 2017). The $R_{\mathrm{d}}$ values determined herein for $\mathrm{U}$ comply with those of solid-liquid distribution coefficients $\left(K_{\mathrm{d}}\right)$ tabulated by the International Atomic Energy Agency (IAEA, 2010) for acidic soils ( $\mathrm{pH}$ ranging between 5 and 7), which cover 4 orders of magnitude (from 2.6 to $6.7 \times 10^{4} \mathrm{~L} \mathrm{~kg}^{-1}$ ). Strictly speaking, quantifying solid-liquid distribution coefficients with $K_{\mathrm{d}}$ values should be restricted to conditions involving adsorption/desorption reactions. As the IAEA database includes $K_{\mathrm{d}}$ values acquired in very different contexts (laboratory vs. field measurement, short-term vs. long-term, etc.) and with different 
methodologies (sorption vs. desorption experiments, etc.) (Vandenhove et al., 2009; RamírezGuinart et al., 2020), their comparison with our $R_{\mathrm{d}}$ data is pertinent.

Desorption of $\mathrm{Pu}$ from the two freshly contaminated soils was also very limited, as expected. Concentrations of $\mathrm{Pu}$ in solution were around $2-3 \times 10^{-12} \mathrm{M}$, that should prevent any hydrolysis and precipitation of $\mathrm{Pu}(\mathrm{IV})$ in solution. These levels are in the typical range measured in environmental water samples, ranging from $10^{-13}$ to $10^{-8} \mathrm{M}$ (Neu et al., 2005). The increasing Pu concentration in the aqueous phase over time suggests that $\mathrm{Pu}$ desorption is under kinetic control for these soils. Kinetic-controlled desorption of $\mathrm{Pu}(\mathrm{IV})$ from hematite, a $\mathrm{Fe}-$ oxide commonly found in soils, has been reported by Romanchuk et al. (2011). The $R_{\mathrm{d}}$ values determined after 7 days of contact with pure water (about $800 \mathrm{~L} \mathrm{~kg}^{-1}$ for the LBS soil and 450 $\mathrm{L} \mathrm{kg}^{-1}$ for the PG one) fall close to the lower boundary of the $K_{\mathrm{d}}$ range reported by the IAEA (2010) for the "loam+clay soils" category (100-9600 $\mathrm{L} \mathrm{kg}^{-1}$ ), as well as that reported by Bugai et al. (2020) for soils from the Chernobyl area (200-6100 $\left.\mathrm{L} \mathrm{kg}^{-1}\right)$. Our results highlight a higher $\mathrm{Pu}$ availability in the PG than in the LBS soil. This finding may appear as counterintuitive, since the PG soil has a much higher clay content than the LBS one. However, other chemical properties may be responsible for a higher availability of $\mathrm{Pu}$ in this soil, such as a higher organic matter content (Marsac et al., 2014; Santchi et al., 2017) that could favor formation of soluble organic Pu complexes.

Besides siderophores, citrate was chosen in our extraction studies because this chelator, which is exuded by the roots of plants, is known to be highly efficient for the recovery of actinides from soils (Francis and Dodge, 2015). This high efficiency of citrate to extract $U$ and $\mathrm{Pu}$ was confirmed in our study, but only for short contact times. After 7 days, the concentrations of $\mathrm{U}$ and $\mathrm{Pu}$ in solution decreased to levels comparable to those obtained with DFB or $\left(\mathrm{L}^{\mathrm{Cy}, \mathrm{Pr}}\right) \mathrm{H}_{2}$. Numerous studies have focused on the use of citric acid as an amendment in combination with hyper-accumulating plants, with the aim of increasing the amount of $U$ transferred to the soil solution and enhancing thereby the efficiency of phytoremediation of $U$ contaminated soils (Ebbs et al., 1998; Huang et al., 1998a; Shahandeh and Hosner, 2002; Duquène et al., 2008; Mihalik et al., 2012; Alam and Cheng, 2014). Citrate is a naturally occurring multidentate ligand that forms stable complexes with actinides, and may involve the formation of bidentate, tridentate, binuclear, or polynuclear species (Francis and Dodge, 2015). Although similarities may be found with our results, the use of citric acid instead of a citrate salt combines the effect of soil acidification to the addition of a chelating agent, which was not our aim. Amending soils with sodium citrate has been shown to increase rapidly their $\mathrm{pH}$ by nearly 1 unit (Yan et al., 
1996), as in this study. By contrast, the use of citric acid typically lowers the $\mathrm{pH}$ of a soil and induces a higher release of $U$ than observed in this study (around 200 or 300-fold increases of U concentrations in solution were recorded by Ebbs et al. (1998) and Huang et al. (1998a) after

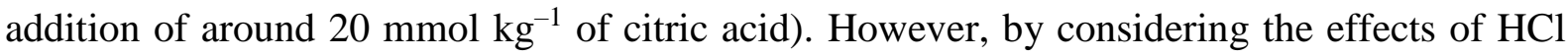
amendment, Ebbs et al. (1998) concluded that the dissolution of $U$ was influenced more by the citrate concentration than by the $\mathrm{pH}$, which makes comparisons between our study and these results pertinent. As found herein, huge amounts of $\mathrm{Fe}$ were released into solution concomitantly to $U$ in all previous studies (Ebbs et al., 1998; Huang et al., 1998a; Duquène et al., 2008; Mihalik et al., 2012, Alam and Cheng, 2014), as a consequence of the enhanced dissolution of Fe oxyhydroxides and silicate minerals by citrate and the possible formation of water-soluble Fe-citrate complexes (Alam and Cheng, 2014). Both Huang et al. (1998a) and Duquène et al. (2008) found a correlation between the $U$ and Fe concentrations in soil solutions following the addition of citric acid or ammonium citrate/citric acid mixtures. However, a most important finding was that the persistence of the increase in U solubility over time was very limited in all studies. It depends on the presence of citrate, the $\mathrm{pH}$, and perhaps additional factors (Ebbs et al., 1998). In parallel to the decrease of $\mathrm{U}$ and $\mathrm{Pu}$ in our experiment, a decrease of citrate between the $1^{\text {st }}$ and $7^{\text {th }}$ day was observed, with only $30 \%$ of the initial amount of added citrate remaining in solution at day 7. Although citrate adsorption on solid soil particles cannot be excluded (Lackovic et al., 2003), its chemical degradation is well documented in the literature and is the preferred explanation. Yan et al. (1996) showed that citrate is rapidly degraded in soils due to microbial activity, leading to the production of $\mathrm{CO}_{2}$. Huang et al. (1998b) reported also a rapid biodegradation of citrate, but found that degradation of U-citrate complexes in soils should be an issue only under basic conditions. Finally, Dodge and Francis (1994) reported that U-citrate complexes could rapidly degrade when exposed to light. As in this study, Ebbs et al. (1998) also observed that the concentrations of the soluble U species produced by citrate amendment of soils was maximal after $24 \mathrm{~h}$ and decreased subsequently, as a result of citric acid degradation over the time scale of their experiments. Moreover, Duquène et al. (2008) showed that the release of $U$ was temporary and started to decrease after one to seven days, depending on the type of soil. Francis and Dodge (2015), who observed a complete biodegradation of citric acid over 18 days in amended soils exposed to air, obtained similar results for $\mathrm{Pu}$. This degradation was accompanied by a decrease of the $\mathrm{Pu}$ released in the solution in the first days after the addition of citric acid. In their experiment, the degradation of citric acid increased the $\mathrm{pH}$ of the soil solution, which in turn favored the precipitation of the actinides released into the solution consequently to the degradation of the citric acid. 
The efficiency of DFB to extract $\mathrm{U}$ and Pu depended on the different contamination scenarios. DFB extracted nearly the same amount of $U$ from soils 1 and 2 than pure water. Considering the variability of the results, the apparent higher efficiency of a $10^{-3} \mathrm{M}$ aqueous DFB solution by comparison with water after a contact time of 7 days for soil 2 most likely results from the heterogeneity of the soil samples and $U$ distribution. By contrast, DFB extracted $\mathrm{Pu}$ from freshly contaminated soils much more efficiently, as the actinide concentration in the solution was ca. 5 to 6 fold higher in the presence of DFB compared to water alone at any contact time. DFB did not affect the $\mathrm{pH}$ of the supernatants, contrary to citrate. In turn, the release in solution of both $\mathrm{U}$ and $\mathrm{Pu}$ was accompanied, as for citrate, by the concomitant dissolution of high amounts of Fe. The highest release of Fe was observed during $\mathrm{U}$ extraction from soils 1 and 2 by DFB. The amount of Fe in solution increased together with the contact time, except in the case of the PG soil for which the maximum extracted quantity by DFB had been reached after 1 day. After 7 days of contact, the Fe concentrations in solution reached nearly the same values for all samples, despite higher iron oxide contents (as measured by the Mehra-Jackson method) in soils 1 and 2, as compared to those of LBS and PG. It should be noted however that DFB has been shown to promote Fe dissolution not only from Fe oxides but also from a lot of other minerals, including phosphates, sulfides, and clay minerals (Neubauer et al., 2000; Cervini-Silva and Sposito, 2002; Wolff-Boenisch and Traina, 2007a; Cervini-Silva et al., 2012). Our experiments confirm these observations, which highlight the ability of DFB to dissolve efficiently Fe-containing minerals whatever their nature, though this process is under kinetic control. As shown by the speciation simulations, the $[\mathrm{Fe}(\mathrm{DFB}) \mathrm{H}]^{+}$complex accounts for only $77 \%$ of total DFB in solution. Although a fraction (ca. 40\%) of the DFB initially introduced in the soils was not recovered in solution, probably due to its adsorption on soil minerals (Ahmed and Holmström, 2014), the remaining was still in excess and free DFB was available to bind to other cations.

The low efficiency of DFB to recover $\mathrm{U}$ as compared to $\mathrm{Pu}$ may be explained by the speciation of $U$ within the soils. Whereas DFB has been shown to desorb $U$ from goethite or kaolinite (Wolff-Boenisch and Traina, 2006, 2007a, 2007b), its efficiency in soils 1 and 2 remained limited in the time scale of our experiments. Since the $U$ source for these soils is a pitchblende vein, $\mathrm{U}$ species adsorbed to iron oxyhydroxides may be present in minor amounts. Kraemer et al. (2015) showed that DFB has the potential to mobilize U from igneous rock samples of different geologic settings through oxidation of U(IV) and formation of $\mathrm{U}(\mathrm{VI}) / \mathrm{DFB}^{3-}$ complexes. However, the release of $\mathrm{U}$ through dissolution of natural $\mathrm{U}$ minerals 
in soils 1 and 2 seems somewhat limited compared to water in our conditions. Considering $\mathrm{Pu}$, the radionuclide in both freshly contaminated LBS and PG soils is assumed to be adsorbed at the surface of mineral particles consisting mainly of iron oxyhydroxides. Hence, its release into solution might most likely result from the dissolution of these Fe minerals by DFB (Neu et al., 2005), although the direct dissolution of amorphous $\mathrm{Pu}$ oxides by the siderophore cannot be excluded, as shown by Brainard et al. (1992) and Neu et al. (2000), even in the presence of Fe oxides. This process is supported by the 2400 -fold higher binding affinity of (DFB) $\mathrm{H}^{2-}$ for $\mathrm{Pu}^{4+}$ than for $\mathrm{Fe}^{3+}$, while the higher coordination number of $\mathrm{Pu}^{4+}(\geq 8)$ allows furthermore the formation of complexes involving two ligands, like $\left[\mathrm{Pu}(\mathrm{DFB})_{2} \mathrm{H}_{4}\right]^{2+}$.

Contrary to water, for which a continuous increase of the Pu concentration in solution with the contact time was observed, or to a $10^{-3} \mathrm{M}$ citrate extraction medium for which both $\mathrm{U}$ and $\mathrm{Pu}$ concentrations decreased over time, the amounts of $\mathrm{U}$ and Pu extracted by DFB did not change between the $1^{\text {st }}$ and $7^{\text {th }}$ day of the experiments. This result is consistent with the fact that the concentration of DFB in solution remained constant over the duration of the extraction, being around $60 \%$ of its initial value. In addition, no degradation of DFB over time that could lead to the potential release of actinides was observed, nor any substantial decrease of $\mathrm{pH}$ compared to water extraction. The efficient sequestration of $\mathrm{U}$ and $\mathrm{Pu}$ by DFB in the form of cationic or neutral species prevents them from further adsorption on iron oxyhydroxide surfaces, which are mainly positively charged at soil $\mathrm{pH}$ around 5 , as shown for goethite by Conroy et al. (2017). As a matter of fact, the identification of hydroxamate-bound $\mathrm{Pu}$ in particulate and colloidal phases of wetland sediments (Xu et al., 2008; 2015) is also consistent with the high stability of plutonium(IV) hydroxamato complexes, exceeding that of the corresponding iron(III) species owing to the higher Lewis acidity of $\mathrm{Pu}^{4+}$ over $\mathrm{Fe}^{3+}$ (Boukhalfa et al., 2007).

The efficiency of the dihydroxamic acid $\left(\mathrm{L}^{\mathrm{Cy}}, \mathrm{Pr}\right) \mathrm{H}_{2}$ for extracting $\mathrm{U}$ is comparable to the one of DFB, except, however, in the case of soil 1, for which a nearly 2-fold higher extraction yield was found. However, $\left(\mathrm{L}^{\mathrm{Cy}}, \mathrm{Pr}\right) \mathrm{H}_{2}$ dissolved lower amounts of $\mathrm{Fe}$ than DFB for both soils. This result can be easily explained by the lower affinity of the dihydroxamic chelator for $\mathrm{Fe}^{3+}$ compared to the natural trihydroxamic DFB, while the affinity for $\mathrm{UO}_{2}{ }^{2+}$ of both compounds remain the same. 


\section{Conclusion}

Thermodynamic complexation studies for different metal-over-ligand concentration ratios enabled to establish the formation of mono- and bischelated uranyl complexes with the trishydroxamate biological iron transporter desferrioxamine $\mathrm{B}$ and the synthetic dihydroxamate RA analog $\left(\mathrm{L}^{\mathrm{Cy}, \mathrm{Pr}}\right)^{2-}$. However, both chelators were found to behave differently, as $\left(\mathrm{L}^{\mathrm{Cy}, \mathrm{Pr}}\right)^{2-}$ forms in addition to 1:1 also 1:2 metal/ligand complexes in the presence of an excess of ligand, while the trihydroxamate $\mathrm{DFB}^{3-}$ produces exclusively 1:1 species under similar experimental conditions. Noteworthy, the latter undergo deprotonation near neutral conditions with $\mathrm{p} K_{\mathrm{a}}{ }^{\prime} \mathrm{s}$ in the range of 6.3-6.9, affording pentacoordinated monohydroxo bischelated complexes with both ligands. Although $\mathrm{DFB}^{3-}$ and $\left(\mathrm{L}^{\mathrm{Cy}, \mathrm{Pr}}\right)^{2-}$ do not possess the same number of protonation sites, nor the same overall basicity, the intrinsic affinity of one, respectively two, hydroxamate unit for $\mathrm{UO}_{2}{ }^{2+}$ is nearly the same for both chelators once the protonation free enthalpy has been factored out. Hence, neither the positive charge borne by the $N$-terminal ammonium group of DFB, nor the hairpin structure of $\left(\mathrm{L}^{\mathrm{Cy}, \mathrm{Pr}}\right)^{2-}$ significantly affects the binding strength, which was found to be also very similar to that exhibited by the monohydroxamate model ligand $\mathrm{NMA}^{-}$ upon forming the five-coordinate $\left[\mathrm{UO}_{2}(\mathrm{NMA})\right]^{+}$and $\left[\mathrm{UO}_{2}(\mathrm{NMA})_{2}\right]$ species. Overall, the affinity for $\mathrm{UO}_{2}{ }^{2+}$ is significantly lower than for $\mathrm{Fe}^{3+}$ and $\mathrm{Pu}^{4+}$ as a combined consequence of lower Lewis acidity and coordination numbers.

The capacity of DFB and $\left(\mathrm{L}^{\mathrm{Cy}, \mathrm{Pr}}\right) \mathrm{H}_{2}$ to extract $\mathrm{U}$ and $\mathrm{Pu}$ from natural uraniferous and freshly $\mathrm{Pu}$-contamined soils into the aqueous phase was evaluated by performing desorption batch experiments. We have also compared their extraction properties with those of citrate, a natural triscarboxylate chelator delivered by plants that is known to form complexes with these cations, while pure water was used as a reference. In addition, as the investigated soils contained large quantities of iron, these actinide extraction experiments were complemented by monitoring the Fe solubilization by citrate and the siderochelates. The experimental results were analyzed in the light of the newly determined thermodynamic data, and simulations of metal cation speciation.

Among the three chelators, citrate showed the highest short-term efficiency to mobilize the actinides in the presence of $\mathrm{Fe}$ : it worked faster, extracted more actinide within a day, whereas after a week its capacity, although still slightly higher, was of the same order of magnitude as that of the hydroxamate siderochelates. The decrease of the water-soluble $\mathrm{U}$ and $\mathrm{Pu}$ fraction in the soil solution over a week was only observed for citrate and could be explained by the decomposition of the complexes and the possible readsorption of the radionuclides on the soil 
particles. Last, but not least, citrate extracted less Fe than DFB from the uraniferous and $\mathrm{Pu}-$ enriched soils. Interestingly, the $\mathrm{U}$ and $\mathrm{Pu}$ concentration levels in the supernatants containing any of the two hydroxamic acids remained nearly constant for both contact times of 1 and 7 days. Nevertheless, comparison of the di- and trihydroxamate chelators showed interesting differences, as the former extracted slightly more uranyl than the latter, while keeping iron take up to a lower level, especially if longer contact times were allowed. The dihydroxamate clearly worked better at uranyl extraction, which is not surprising, because the uranyl dication has two available sites for chelation, when $\mathrm{Fe}^{3+}$ has three. In addition, the dihydroxamate shows a better $\mathrm{U} / \mathrm{Fe}$ selectivity at the early stages of the extraction process.

From an environmental point of view, this study is highly relevant as it demonstrates the rather low efficiency of hydroxamic soil siderophores to mobilize $\mathrm{UO}_{2}$ in mining areas upon formation of water-soluble, fast migrating U(VI) complexes, which could eventually end up in the aquifers. The main reason is the exceedingly higher affinity of (DFB) $\mathrm{H}^{2-}$ for $\mathrm{Fe}^{3+}$ over $\mathrm{UO}_{2}{ }^{2+}$. Interestingly, the dihydroxamate ligands are slightly more efficient than their trishydroxamate counterparts in dissolving $\mathrm{UO}_{2}$, because they compete less with Fe. As far as $\mathrm{Pu}$ is concerned, the situation appears much more critical, as DFB selectivity binds the radionuclide. It turns out that a significant fraction (up to $13 \%$ in one of our experiments) of sorbed $\mathrm{Pu}$ can be extracted into the soil solution in the form of water-soluble $\mathrm{Pu}(\mathrm{IV})$ complexes, making the highly toxic radionuclide bioavailable for microbial uptake by some soil bacteria and, most importantly, greatly facilitating its dissemination in soils and water streams. This study clearly highlights the necessity to consider the siderophore-mediated transport of plutonium in the geochemical modelling of contaminated areas.

\section{Declaration of competing interest}

The authors declare that they have no known competing financial interests or personal relationships that could have appeared to influence the work reported in this paper.

\section{Acknowledgments}

This work was partially funded by the French program Défi NEEDS Environnement (project ACTISOL). The Institut de Radioprotection et de Sûreté Nucléaire (IRSN), the Centre National de la Recherche Scientifique (CNRS), the Conseil Régional de Bourgogne (CRB, program PARI II CDEA), the European Regional Development Fund (FEDER), and the Agence Nationale de la Recherche (ANR, project Chelan) are gratefully acknowledged for their 
financial support. L.N. is in debt to the CRB and the Commissariat à l'Energie Atomique et aux Energies Alternatives (CEA), and N.Z. to the Ministère de l'Enseignement Supérieur et de la Recherche (MESR) for granting their PhD fellowship. Authors also express warm thanks to D. Orjollet and L. Carasco from IRSN/LR2T for U and Pu measurements, respectively.

\section{References}

Ahmed, E., Holmström, S.J.M., 2014. The effect of soil horizon and mineral type on the distribution of siderophores in soil. Geochim. Cosmochim. Acta 131, 184-195.

Alam, M.S., Cheng, T., 2014. Uranium release from sediment to groundwater: Influence of water chemistry and insights into release mechanisms. J. Cont. Hydrol. 164, 72-87.

Atkin, C.L., Neilands, J.B., 1968. Rhodotorulic acid, a diketopiperazine dihydroxamic acid with growth-factor activity. I. Isolation and characterization. Biochemistry 7, 3734-3739.

Baes, C.F., Mesmer, R.E., 1976. The Hydrolysis of Cations, John Wiley and Sons, New York.

Barclay, S.J., Huynh, B.H., Raymond, K.N., 1984. Coordination chemistry of microbial iron transport compounds. 27. Dimeric iron(III) complexes of dihydroxamate analogs of rhodotorulic acid. Inorg. Chem. 23, 2011-2018.

Boukhalfa, H., Crumbliss, A.L., 2002. Chemical aspects of siderophore mediated iron transport. BioMetals 15, 325-339.

Boukhalfa, H., Reilly, S.D., Neu, M.P., 2007. Complexation of Pu(IV) with the natural siderophore desferrioxamine $\mathrm{B}$ and the redox properties of $\mathrm{Pu}(\mathrm{IV})($ siderophore) complexes. Inorg. Chem. 46, 1018-1026.

Brainard, J.R., Strietelmeier, B.A., Smith, P.H., Langston-Unkefer, P.J., Barr, M.E., Ryan, R.R., 1992. Actinide binding and solubilization by microbial siderophores. Radiochim. Acta $58-59,357-363$.

Brédoire, F. 2012. Caractérisation de l'impact de l'exsudation de citrate par les racines protéoïdes du lupin blanc (Lupinus albus cv. amiga) sur la phytodisponibilité de l'uranium naturellement présent dans un sol. Master 2 Université de Lorraine - ENSAIA, IRSN report. 
Bugai, D., Smith, J., Hoque, M.A., 2020. Solid-liquid distribution coefficients (Kd-s) of geological deposits at the Chernobyl Nuclear Power Plant site with respect to $\mathrm{Sr}, \mathrm{Cs}$ and $\mathrm{Pu}$ radionuclides: A short review. Chemosphere 242, 125175.

Carrano, C.J., Cooper, S.R., Raymond, K.N., 1979. Coordination chemistry of microbial iron transport compounds. 11. Solution equilibriums and electrochemistry of ferric rhodotorulate complexes. J. Am. Chem. Soc. 101, 599-604.

Cervini-Silva, J., Sposito, G., 2002. Steady-state dissolution kinetics of aluminum-goethite in the presence of desferrioxamine-B and oxalate ligands. Environ. Sci. Technol. 36, 337-342.

Cervini-Silva, J., Kearns, J., Banfield, J., 2012. Steady-state dissolution kinetics of mineral ferric phosphate in the presence of desferrioxamine- $\mathrm{B}$ and oxalate ligands at $\mathrm{pH}=4-6$ and $\mathrm{T}=24 \pm 0.6^{\circ} \mathrm{C}$. Chem. Geol. 320-321, 1-8.

Choppin, G.R., 2003. Actinide speciation in the environment. Radiochim. Acta 91, 645-649.

Conroy, N.A., Zavarin, M., Kersting, A.B., Powell, B.A., 2017. Effect of natural organic matter on plutonium sorption to goethite. Environ. Sci. Technol. 51, 699-708.

Denison, F., 2002. Application of chemical speciation modelling to uranium toxicity and bioavailability studies: Compilation of a coherent database for simple experimental systems and an investigation of the database uncertainty on the model predictions. IRSN. p. 162.

Denison, F.H., Garnier-Laplace, J., 2005. The effects of database parameter uncertainty on uranium(VI) equilibrium calculations. Geochim. Cosmochim. Acta 69, 2183-2191.

Dodge, C.J., Francis, A.J., 1994. Photodegradation of uranium-citrate complex with uranium recovery. Environ. Sci. Technol. 28, 1300-1306.

Dong, W., Brooks, S.C., 2006. Determination of the formation constants of ternary complexes of uranyl and carbonate with alkaline earth metals $\left(\mathrm{Mg}^{2+}, \mathrm{Ca}^{2+}, \mathrm{Sr}^{2+}\right.$, and $\left.\mathrm{Ba}^{2+}\right)$ using anion exchange method. Environ. Sci. Technol. 40, 4689-4695.

Dong, W., Brooks, S.C., 2008. Formation of aqueous $\mathrm{MgUO}_{2}\left(\mathrm{CO}_{3}\right)_{3}{ }^{2-}$ complex and uranium anion exchange mechanism onto an exchange resin. Environ. Sci. Technol. 42, 1979-1983.

Duckworth, O.W., Sposito, G., 2005. Siderophore-manganese(III) interactions. I. Air-oxidation of manganese(II) promoted by desferrioxamine B. Environ. Sci. Technol. 39, 6037-6044. 
Duquène, L., Tack, F., Meers, E., Baeten, J., Wannijn, J., Vandenhove, H., 2008. Effect of biodegradable amendments on uranium solubility in contaminated soils. Sci. Total Environ. 391, 26-33.

Ebbs, S.D., Brady, D.J., Kochian, L.V., 1998. Role of uranium speciation in the uptake and translocation of uranium by plants. J. Exp. Bot. 49, 1183-11990.

Essén, S.A., Johnsson, A., Bylund, D., Pedersen, K., Lundström, U.S., 2007. Siderophore production by Pseudomonas stutzeri under aerobic and anaerobic conditions. Appl. Environ. Microbiol. 73, 5857-5864.

Evers, A., Hancock, R.D., Martell, A.E., Motekaitis, R.J., 1989. Metal ion recognition in ligands with negatively charged oxygen donor groups. complexation of Fe(III), Ga(III), In(III), Al(III), and other highly charged metal ions. Inorg. Chem. 28, 2189-2195.

Farkas, E., Enyedy, É.A., Csóka, H., 1999. A comparison between the chelating properties of some dihydroxamic acids, desferrioxamine B and acetohydroxamic acid. Polyhedron 18, $2391-2398$.

Farkas, E., Buglyó, P., Enyedy, E.A., Gerlei, V.A., Santos, A.M., 2002. Factors affecting the metal ion-hydroxamate interactions: effect of the position of the peptide function in the connecting chain on the $\mathrm{Fe}(\mathrm{III}), \mathrm{Mo}(\mathrm{VI})$ and $\mathrm{V}(\mathrm{V})$ complexation of some new desferrioxamine B (DFB) model dihydroxamic acids. Inorg. Chim. Acta 339, 215-223.

Farkas, E., Buglyó, P., Enyedy, E.A., Santos, M.A., 2004. Factors affecting the metal ionhydroxamate interactions II: effect of the length of the connecting chain on the Fe(III), Mo(VI) and V(V) complexation of some new desferrioxamine B (DFB) model dihydroxamic acids. Inorg. Chim. Acta 357, 2451-2461.

Francis, A.J., Dodge, C.J., 2015. Microbial mobilization of plutonium and other actinides from contaminated soil. J. Environ. Radioact. 150, 277-285.

Frazier, S.W., Kretzschmar, R., Kraemer, S.M., 2005. Bacterial siderophores promote dissolution of $\mathrm{UO}_{2}$ under reducing conditions. Environ. Sci. Technol. 39, 5709-5715.

Gampp, H., Maeder, M., Meyer, C.J., Zuberbühler, A.D., 1985a. Calculation of equilibrium constants from multiwavelength spectroscopic data-I Mathematical considerations. Talanta $32,95-101$. 
Gampp, H., Maeder, M., Meyer, C.J., Zuberbühler, A.D., 1985b. Calculation of equilibrium constants from multiwavelength spectroscopic data-II Specfit: two user-friendly programs in basic and standard fortran 77. Talanta 32, 257-264.

Gans, P., Sabatini, A., Vacca, A., 1996. Investigation of equilibria in solution. Determination of equilibrium constants with the HYPERQUAD suite of programs. Talanta 43, 1739-1753.

Geipel, G., Amayri, S., Bernhard, G., 2008. Mixed complexes of alkaline earth uranyl carbonates: a laser-induced time-resolved fluorescence spectroscopic study. Spectrochim. Acta, Part A 71, 53-58.

Groenewold, G.S., Van Stipdonk, M.J., Gresham, G.L., Chien, W., Bulleigh, K., Howard, A., 2004. Collision-induced dissociation tandem mass spectrometry of desferrioxamine siderophore complexes from electrospray ionization of $\mathrm{UO}_{2}{ }^{2+}, \mathrm{Fe}^{3+}$ and $\mathrm{Ca}^{2+}$ solutions. $\mathrm{J}$. Mass Spectrom. 39, 752-761.

Henner, P., Brédoire, F., Tailliez, A., Coppin, F., Pierrisnard, S., Camilleri, V., Keller, C., 2018. Influence of root exudation of white lupine (Lupinus albus L.) on uranium phytoavailability in a naturally uranium-rich soil. J. Environ. Radioact. 190-191, 39-50.

Hernlem, B.J., Vane, L.M., Sayles, G.D., 1996. Stability constants for complexes of the siderophore desferrioxamine B with selected heavy metal cations. Inorg. Chim. Acta 244, $179-184$.

Huang, J.W., Blaylock, M.J., Kapulnik, Y., Ensley, B.D., 1998a. Phytoremediation of uraniumcontaminated soil: role of organic acid in triggering uranium hyperaccumulation in plants. Environ. Sci. Technol. 32, 2004-2008.

Huang, F.Y.C., Brady, P.V., Lindgren, A.R., Guerra, P., 1998b. Biodegradation of UraniumCitrate Complexes: Implications for Extraction of Uranium from Soils. Environ. Sci. Technol. 1998, 32, 379-382

IAEA (International Atomic Energy Agency), 2010. TRS-472 Handbook of parameter values for the prediction of radionuclide transfer in terrestrial and freshwater environments. International Atomic Energy Agency. Austria. 
Ibragimov, R., 2020. Lake Karachay as a source of groundwater pollution. Bachelor's thesis. Hämeenlinna University Centre, Degree Programme in Construction Engineering. Häme University of Applied Science, Finland.

Jabiol, B., Zanella, A., Ponge, J.-F., Sartori, G., Englisch, M., van Delft, B., de Waal, R., Le Bayon, R.-C., 2013. A proposal for including humus forms in the World Reference Base for Soil Resources (WRB-FAO). Geoderma 192, 286-294.

Jarvis, N.V., Hancock, R.D., 1991. Some correlations involving the stability of complexes of transuranium metal ions and ligands with negatively charged oxygen donors. Inorg. Chim. Acta 182, 229-232.

Kaplan, D., Powell, B.A., Duff, M.C., Demirkanli, D.I., Denham, M., Fjeld, R.A., Molz, F.J., 2007. Influence of sources on plutonium mobility and oxidation state transformations in vadose zone sediments. Environ. Sci. Technol. 41, 7417-7423

Keith-Roach, M.J., Vetri Buratti, M., Worsfold, P.J., 2005. Thorium complexation by hydroxamate siderophores in perturbed multicomponent systems using flow injection electrospray ionization mass spectrometry. Anal. Chem. 77, 7335-7341.

Kraemer, D., Kopf, S., Bau, M., 2015. Oxidative mobilization of cerium and uranium and enhanced release of "immobile" high field strength elements from igneous rocks in the presence of the biogenic siderophore desferrioxamine B. Geochim. Cosmochim. Acta 165, 263-279.

Lackovic, K., Johnson, B.B, Angove, M.J., Wells, J.D., 2003. Modeling the adsorption of citric acid onto Muloorina illite and related clay minerals. J. Col. Int. Sci. 267, 49-59.

Liu, B., Peng, T., Sun, H., Yue, H., 2017. Release behavior of uranium in uranium mill tailings under environmental conditions. J. Environ. Radioact. 171, 160-168.

Lofts, S., Fevrier, L., Horemans, N., Gilbin, R., Bruggeman, C., Vandenhove, H., 2015. Assessment of co-contaminant effects on uranium and thorium speciation in freshwater using geochemical modelling. J. Environ. Radioact. 149, 99-109.

Marsac, R., Banik, N.L., Marquardt, C.M., Kratz, J.V., 2014. Stabilization of polynuclear plutonium(IV) species by humic acid. Geochim. Cosmochim. Acta 2014, 290-300. 
Martell, A.E., Smith, R.M., Motekaitis, R.J., 2004. NIST Critically Selected Stability Constants of Metal Complexes Database, 8.0 ed., NIST Standard Reference Database No. 46, Gaithersburg, MD.

Meyer, M., Burgat, R., Faure, S., Batifol, B., Hubinois, J.-C., Chollet, H., Guilard, R., 2007. Thermodynamic studies of actinide complexes. 1. A reappraisal of the solution equilibria between plutonium(IV) and ethylenediaminetetraacetic acid $\left(\mathrm{EDTAH}_{4}\right)$ in nitric media. $\mathrm{C}$. R. Chimie 10, 929-947.

Mihalík, J., Henner, P., Frelon, S., Camilleri, V., Février, L., 2012. Citrate assisted phytoextraction of uranium by sunflowers: Study of fluxes in soils and plants and resulting intra-planta distribution of Fe and U. Environ. Exp. Bot. 77, 249-258.

Mullen, L., Gong, C., Czerwinski, K.J., 2007. Complexation of uranium (VI) with the siderophore desferrioxamine B. J. Radioanal. Nucl. Chem., 273, 683-688.

Neu, M.P., Matonic, J.H., Ruggiero, C.E., Scott, B.L., 2000. Structural characterization of a plutonium(IV) siderophore complex: Single-crystal structure of Pu-desferrioxamine E. Angew. Chem. Int. Ed. 39, 1442-1444.

Neu, M.P., Icopini, G.A., Boukhalfa, H., 2005. Plutonium speciation affected by environmental bacteria. Radiochim. Acta 93, 705-714.

Neubauer, U., Nowack, B., Furrer, G., Schulin, R., 2000. Heavy metal sorption on clay minerals affected by the siderophore desferrioxamine B. Environ. Sci. Technol. 34, 2749-2755.

Nguyen-van-Duong, M.K., Guillot, V., Nicolas, L., Gaudemer, A., Lowry, L., Spasojević, I., Crumbliss, A.L., 2001. Synthesis, ligand $\mathrm{p} K_{\mathrm{a}}$, and Fe(III) complexation constants for a series of bipodal dihydroxamic acids. Inorg. Chem. 40, 5948-5953.

Novikov, A.P., Kalmykov, S.N., Utsunomiya, S., Ewing, R.C., Horreard, F., Merkulov, A., Clark, S.B., Tkachev, V.V., Myasoedov, B.F., 2006. Colloid transport of plutonium in the far-field of the Mayak production association, Russia. Science 314, 638-641.

Perrin, D.D., Dempsey, B., 1974. Buffers for pH and Metal Ion Control, Chapman and Hall, London. 
Pfeiffer, H.-R., Vust, M., Meisser, N., 1994. Uranium-enrichment in soils and plants in the vicinity of a pitchblende vein at La Creusaz/Les Marécottes (W of Martigny, Valais, Switzerland). Eclogae geol. Helv. 87/2, 491-501.

Powell, P.E., Cline, G.R., Reid, C.P.P., Szaniszlo, P.J., 1980. Occurrence of hydroxamate siderophore iron chelators in soils. Nature 287, 833-834.

Protonic Software, http://www.hyperquad.co.uk/.

Ramírez-Guinart, O., Kaplan, D., Rigol, A., Vidal, M., 2020. Deriving probabilistic soil distribution coefficients $\left(\mathrm{K}_{\mathrm{d}}\right)$. Part 1: General approach to decreasing and describing variability and example using uranium $K_{d}$ values. J. Environ. Radioact. 222, 106362.

Référentiel Pédologique, 2008. Baize D., Girard M.-C. (Eds.), Association Française pour l'Etude du Sol (AFES), Editions Quae, Versailles.

Romanchuk, A.Y., Kalmykov, S.N., Aliev, R.A., 2011. Plutonium sorption onto hematite colloids at femto- and nanomolar concentrations. Radiochim. Acta 99, 1-8.

Rout, S., Ravi, P.M., Kumar, A., Tripathi, R.M., 2015. Study on speciation and salinity-induced mobility of uranium from soil. Environ. Earth Sci. 74, 2273-2281.

Ruggiero, C.E., Matonic, J.H., Reilly, S.D., Neu, M.P., 2002. Dissolution of plutonium(IV) hydroxide by desferrioxamine siderophores and simple organic chelators. Inorg. Chem. 41, 3593-3595.

Santschi, P.H., Xu C., Zhang, S., Schwehr, K.A., Lin, P., Yeager, C.M., Kaplan, D.I., 2017. Recent advances in the detection of specific natural organic compounds as carriers for radionuclides in soil and water environments, with examples of radioiodine and plutonium J. Environ. Radioact. 171, 226-233.

Schwarzenbach, G., Schwarzenbach, K., 1963. Hydroxamatkomplexe I. Die Stabilität der Eisen(III)-Komplexe einfacher Hydroxamsäuren und des Ferrioxamins B. Helv. Chim. Acta 46, 1390-1400.

Shahandeh, H., Hossner, L.R., 2002. Enhancement of uranium phytoaccumulation from contaminated soils. Soil Sci. 167, 269-280. 
Sladkov, V., Roques, J., Meyer, M., 2020. Assignment of complex species by affinity capillary electrophoresis: the case of Th(IV)-desferrioxamine B. Electrophoresis 41, 1870-1877.

Sornosa-Ten, A., Jewula, P., Fodor, T., Brandès, S., Sladkov, V., Rousselin, Y., Stern, C., Chambron, J.-C., Meyer, M., 2018. Effects of preorganization in the chelation of $\mathrm{UO}_{2}{ }^{2+}$ by hydroxamate ligands: cyclic PIPO ${ }^{-}$vs. linear NMA- New J. Chem. 42, 7765-7779.

Van der Lee, J., De Windt, L., 1999. JCHESS. Ecole des Mines de Paris.

Van der Lee, J., Lomenech, C., 2004. Towards a common thermodynamic database for speciation models. Radiochim. Acta 92, 811-818.

Vandenhove, H., Gil-García, C., Rigol, A., Vidal, M., 2009. New best estimates for radionuclide solid-liquid distribution coefficients in soils. Part 2. Naturally occurring radionuclides. J. Environ. Radioact. 100, 697-703.

Vandenhove, H., Vanhoudt, N., Duquène, L., Antunes, K., Wannijn, J., 2014. Comparison of two sequential extraction procedures for uranium fractionation in contaminated soils. J. Environ. Radioact. 137, 1-9.

Vercouter, T., Reiller, P.E., Ansoborlo, E., Février, L., Gilbin, R., Lomenech, C., Philippini, V., 2015. A modelling exercise on the importance of ternary alkaline earth carbonate species of uranium(VI) in the inorganic speciation of natural waters. Appl. Geochem. 55, 192-198.

Whisenhunt, D.W., Neu, M.P., Hou, Z., Xu, J., Hoffman, D.C., Raymond, K.N., 1996. Specific sequestering agents for the actinides. 29. Stability of the thorium(IV) complexes of desferrioxamine B (DFO) and three octadentate catecholate or hydroxypyridinonate DFO derivatives: DFOMTA, DFOCAMC, and DFO-1,2-HOPO. Comparative stability of the plutonium(IV) DFOMTA complex. Inorg. Chem. 35, 4128-4136.

Wolff-Boenisch, D., Traina, S.J., 2006. A comparative study of the effect of desferrioxamine $\mathrm{B}$, oxalic acid, and Na-alginate on the desorption of U(VI) from goethite at $\mathrm{pH} 6$ and $25^{\circ} \mathrm{C}$. Geochim. Cosmochim. Acta 70, 3456-3466.

Wolff-Boenisch, D., Traina, S.J., 2007a. The effect of desferrioxamine B on the desorption of $\mathrm{U}(\mathrm{VI})$ from Georgia kaolinite $\mathrm{KGa}-1 \mathrm{~b}$ and its ligand-promoted dissolution at $\mathrm{pH} 6$ and 25 ${ }^{\circ} \mathrm{C}$. Chem. Geol. 242, 278-287. 
Wolff-Boenisch, D., Traina, S.J., 2007b. The effect of desferrioxamine B, enterobactin, oxalic acid, and Na-alginate on the dissolution of uranyl-treated goethite at $\mathrm{pH} 6$ and $25{ }^{\circ} \mathrm{C}$. Chem. Geol. 243, 357-368.

Xu, C., Santschi, P.H., Zhong, J.Y., Hatcher, P.G., Francis, A.J., Dodge, C.J., Roberts K.A., Hung, C.-C., Honeyman, B.D., 2008. Colloidal cutin-like substances cross-linked to siderophore decomposition products mobilizing plutonium from contaminated soils. Environ. Sci. Technol. 42, 8211-8217.

Xu, C., Zhang, S., Kaplan, D.I., Ho, Y.-F., Schwehr, K.A., Roberts, K.A., Chen, H.M., Didonato, N., Athon, M., Hatcher, P.G., Santschi, P.H., 2015. Evidence for hydroxamate siderophores and other N-containing organic compounds controlling ${ }^{239,240} \mathrm{Pu}$ immobilization and remobilization in a wetland sediment. Environ. Sci. Technol. 49, 1145811467.

Yan, F., Schubert, S., Mengel, K., 1996. Soil pH increase due to biological decarboxylation of organic anions. Soil Biol. Biochem. 28, 611-624.

Zhao, P., Begg, J.D., Zavarin, M., Tumey, S.J., Williams, R., Dai, Z.R., Kips, R., Kersting, A.B., 2016. Plutonium(IV) and (V) sorption to goethite at sub-femtomolar to micromolar concentrations: Redox transformations and surface precipitation. Environ. Sci. Technol. 50, 6948-6956.

Zheng, Z., Wan, J., 2005. Release of contaminant U(VI) from soils. Radiochim. Acta 93, 211217. 
Efficiency of dihydroxamic and trihydroxamic siderochelates to extract uranium and plutonium from contaminated soils

\author{
Supplementary material
}




\section{Ligand synthesis}

\subsection{Chemicals and materials}

All solvents and chemicals were purchased from Acros Organics or Sigma-Aldrich, and used without further purification unless otherwise noted. Dichloromethane and tetrahydrofuran were previously dried over alumina and stored under nitrogen. $\mathrm{Pd} / \mathrm{C} 10 \%$ was activated before use by heating at $100{ }^{\circ} \mathrm{C}$ under vacuum for at least $3 \mathrm{~h}$. $\mathrm{N}$-methyl-O-benzylhydroxylamine was prepared following previously described procedures. ${ }^{1-3}$ Silica gel 60 (40-60 $\mu \mathrm{m}$, SigmaAldrich) was used for column chromatography. Analytical thin-layer chromatography (TLC) was carried out using Merck silica gel 60 F-254 plates (precoated sheets, $0.2 \mathrm{~mm}$ thick, with fluorescence indicator F254).

\subsection{Instrumentation}

Physicochemical characterizations were performed at the "Plateforme d'Analyses Chimiques et de Synthèse Moléculaire de l'Université de Bourgogne" (PACSMUB-WPCM platform, http://www.wpcm.fr), the technological platform for chemical analysis and molecular synthesis of the Institut de Chimie Moléculaire de l'université de Bourgogne. ${ }^{1} \mathrm{H}$ and ${ }^{13} \mathrm{C}$ NMR spectra were recorded in either $\mathrm{CDCl}_{3}$ or $\mathrm{D}_{2} \mathrm{O}$ as solvent on a Bruker Avance III spectrometer operating at $500 \mathrm{MHz}$. All chemical shifts are given in ppm. The residual $\mathrm{CHCl}_{3}$ solvent peak was used as internal standard (7.26 and $77.16 \mathrm{ppm}$ for ${ }^{1} \mathrm{H}$ and ${ }^{13} \mathrm{C} \mathrm{NMR}$, respectively). Dioxane was used as internal standard (3.75 and $67.17 \mathrm{ppm}$ for ${ }^{1} \mathrm{H}$ and ${ }^{13} \mathrm{C}$ NMR, respectively) for $\mathrm{D}_{2} \mathrm{O}$ solutions. The unambiguous assignment of the ${ }^{1} \mathrm{H}$ and ${ }^{13} \mathrm{C}$ signals in the $1 \mathrm{D}$ NMR spectra relied on gradient-enhanced HSQC, HMBC, and COSY 2D correlation experiments. Mass spectra were recorded on a Bruker Microflex LRF mass spectrometer in the MALDI/TOF reflectron mode using dithranol as matrix. The $\mathrm{CHN}$ elemental analyses were performed on a Thermo Electron Flash 1112 analyzer.

\subsection{Synthesis of N-methyl-N-(benzyloxy)glutaramide (1)}

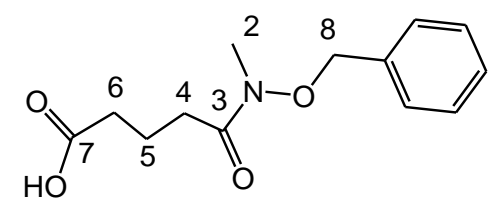

This compound was synthesized following a modified procedure already described by Miller. ${ }^{4}$ To a solution of glutaric anhydride $(3.32 \mathrm{~g}, 29.15 \mathrm{mmol})$ in tetrahydrofuran $(30 \mathrm{~mL})$ under nitrogen atmosphere was added dropwise a solution of $\mathrm{N}$-methyl- $O$ benzylhydroxylamine $(4.00 \mathrm{~g}, 29.15 \mathrm{mmol}$ ) dissolved in $20 \mathrm{~mL}$ of tetrahydrofuran. The reaction 
mixture was stirred for at least $24 \mathrm{~h}$ at room temperature. After evaporation of the solvent, the oily residue was purified by column chromatography (silica gel, $\mathrm{CH}_{2} \mathrm{Cl}_{2} / \mathrm{MeOH}$ 95:5) to provide compound 1 as a colorless oil (5.32 g, $72 \%$ yield).

${ }^{1} \mathrm{H}$ NMR (500.12 MHz, $\mathrm{CDCl}_{3}, 300 \mathrm{~K}$ ): $\delta=7.373$ (m, 5H; Ar), 4.811 (s, 2H; 8-H), 3.198 (s, 3H; 2-H), 2.450 (t, J = 7.2 Hz, 2H; 4-H), 2.371 (t, J = $7.2 \mathrm{~Hz}, 2 \mathrm{H} ; 6-\mathrm{H}), 1.903$ (p, J = $7.2 \mathrm{~Hz}$, $2 \mathrm{H} ; 5-\mathrm{H}) \mathrm{ppm}$.

${ }^{13} \mathrm{C} \mathrm{NMR}\left(125.75 \mathrm{MHz}, \mathrm{CDCl}_{3}, 300 \mathrm{~K}\right): \delta=178.58$ (7-C), $174.62(3-\mathrm{C}), 134.46\left(\mathrm{C}_{\mathrm{Ar}}\right), 129.42$ $\left(\mathrm{CH}_{\mathrm{Ar}}\right), 129.14\left(\mathrm{CH}_{\mathrm{Ar}}\right), 128.84\left(\mathrm{CH}_{\mathrm{Ar}}\right), 76.35$ (8-C), 33.62 (2-C), 33.30 (6-C), 31.15 (4-C), $19.60(5-\mathrm{C}) \mathrm{ppm}$.

Elemental analysis calcd for $\mathrm{C}_{13} \mathrm{H}_{17} \mathrm{NO}_{4}$ (251.28): C 62.14\%; H 6.82\%; N 5.57\%. Found, C $61.77 \% ; \mathrm{H} 7.76 \%$; N 5.94\%.

MALDI-TOF MS: Calcd for $\left[\mathrm{C}_{13} \mathrm{H}_{17} \mathrm{NO}_{4}+\mathrm{H}\right]^{+}$252.123, found 251.907; Calcd for $\left[\mathrm{C}_{13} \mathrm{H}_{17} \mathrm{NO}_{4}\right.$ $+\mathrm{Na}]^{+}$274.105, found 273.916; Calcd for $\left[\mathrm{C}_{13} \mathrm{H}_{17} \mathrm{NO}_{4}+\mathrm{K}\right]^{+} 290.078$, found 289.913.

1.4. Synthesis of $N, N$ '-bis(N''-methyl-N''-benzyloxyglutaramoyl)-( \pm )-1,2-cyclohexanediamine (2)

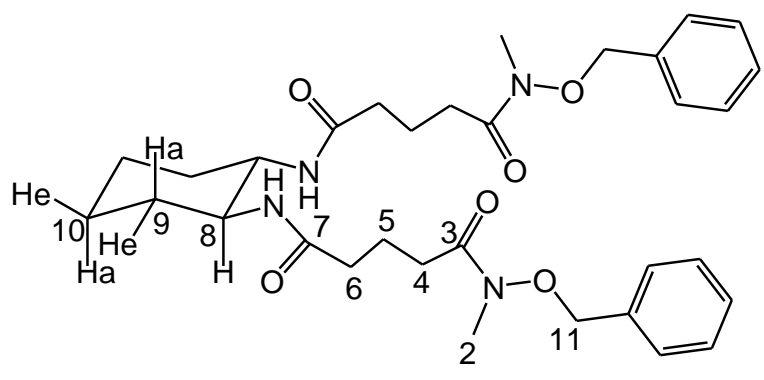

To a solution of acid 1 (4.30 g, $17.11 \mathrm{mmol})$ in dried dichloromethane $(60 \mathrm{~mL})$ under nitrogen atmosphere was added a solution of $( \pm)$-cyclohexanediamine $(977 \mathrm{mg}, 8.55 \mathrm{mmol})$ in $10 \mathrm{~mL}$ of dichloromethane. The reaction mixture was cooled to $5{ }^{\circ} \mathrm{C}$ and 1 hydroxybenzotriazole monohydrate $(524 \mathrm{mg}, 3.42 \mathrm{mmol}$ ) was added followed by a suspension in dichloromethane (20 mL) of 1-ethyl-3-(3-dimethylaminopropyl)carbodiimide hydrochloride $(3.28 \mathrm{~g}, 17.11 \mathrm{mmol})$. The reaction mixture was stirred for at least $24 \mathrm{~h}$ at room temperature after which a citric acid solution ( $40 \mathrm{~mL}, 0.5 \mathrm{M}$ ) was added. After standard work up, the organic solution was washed by a diluted sodium carbonate solution and dried over $\mathrm{MgSO}_{4}$. The crude product was then purified by column chromatography (silica gel, $\mathrm{CH}_{2} \mathrm{Cl}_{2} / \mathrm{MeOH}$ mixtures from 95:5 to $92: 8)$ to afford compound 2 as a white solid (4.38 g, $88 \%$ yield). 
${ }^{1} \mathrm{H}$ NMR (500.13 MHz, $\mathrm{CDCl}_{3}, 300 \mathrm{~K}$ ): $\delta=7.364$ (m, 5H; Ar), 6.268 (s, 2H; NH), 4.805 (s, 2H; 11-H), 3.592 (m, 2H; 8-H), 3.165 (s, 6H; 2-H), 2.412 (t, J = 6.9 Hz, 4H; 4-H), 2.131 (m, 4H; 6-H), 1.986 (m, 2H; 9e-H), 1.856 (m, 4H; 5-H), 1.695 (m, 2H; 10-H), 1.264 (m, 2H; 10'H), 1.183 (m, 2H; 9a-H) ppm.

${ }^{13} \mathrm{C} \mathrm{NMR}\left(125.75 \mathrm{MHz}, \mathrm{CDCl}_{3}, 300 \mathrm{~K}\right): \delta=174.57$ (3-C), 173.39 (7-C), $134.63\left(\mathrm{C}_{\mathrm{Ar}}\right), 129.36$ $\left(\mathrm{CH}_{\mathrm{Ar}}\right), 129.06\left(\mathrm{CH}_{\mathrm{Ar}}\right), 128.81\left(\mathrm{CH}_{\mathrm{Ar}}\right), 76.36$ (11-C), 53.83 (8-C), 35.91 (6-C), 33.63 (2-C), 32.38 (9-C), 31.23 (4-C), 24.76 (10-C), 20.83 (5-C) ppm.

Elemental analysis calcd for $\mathrm{C}_{32} \mathrm{H}_{44} \mathrm{~N}_{4} \mathrm{O}_{6}$ (580.72): $\mathrm{C}$ 66.18\%; $\mathrm{H} 7.64 \%$; $\mathrm{N} 9.65 \%$. Found, $\mathrm{C}$ $65.88 \% ; \mathrm{H} 7.64 \%$; N $9.65 \%$.

MALDI-TOF MS: Calcd for $\left[\mathrm{C}_{32} \mathrm{H}_{44} \mathrm{~N}_{4} \mathrm{O}_{6}+\mathrm{H}\right]^{+}$581.533, found 581.345; Calcd for $\left[\mathrm{C}_{32} \mathrm{H}_{44} \mathrm{~N}_{4} \mathrm{O}_{6}+\mathrm{Na}\right]^{+}$603.315, found 603.330; Calcd for $\left[\mathrm{C}_{32} \mathrm{H}_{44} \mathrm{~N}_{4} \mathrm{O}_{6}+\mathrm{K}\right]^{+}$619.289, found 619.318 .

\subsection{Synthesis of $N, N$ '-bis( $N$ '-methyl-N' $N$-hydroxyglutaramoyl)-( \pm -1,2-cyclohexanediamine} $\left(\left(L^{C y, P r}\right) H_{2}\right)$

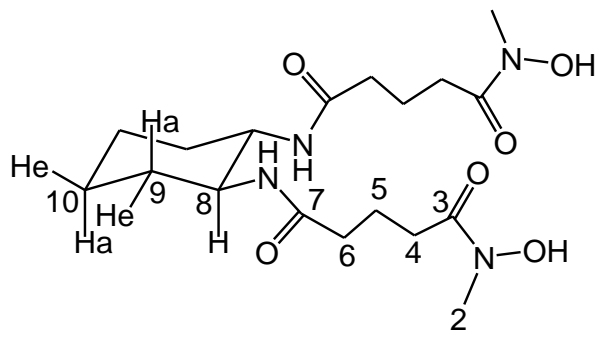

All glassware used for the debenzylation reaction was washed with hydrochloric acid and water in order to remove traces of iron(III). Compound 2 (4.12 g, $7.09 \mathrm{mmol})$ was dried under vacuum in a two-neck round bottom flask and dissolved in $100 \mathrm{~mL}$ of methanol and $200 \mathrm{mg}$ of $\mathrm{Pd} / \mathrm{C} 10 \%$ (activated during $3 \mathrm{~h}$ under vacuum at $100{ }^{\circ} \mathrm{C}$ ) was added under nitrogen atmosphere. The flask was evacuated few seconds under vacuum and then filled with 1 bar of hydrogen gas. After stirring the reaction mixture for at least $6 \mathrm{~h}$, the $\mathrm{Pd} / \mathrm{C}$ catalyst was removed by filtration through a $0.2 \mu \mathrm{m}$ Whatman ${ }^{\mathrm{TM}}$ membrane. Evaporation of the solvent afforded compound 3 as a white solid (2.78 g, 97\% yield).

${ }^{1} \mathrm{H}$ NMR (500.13 MHz, D $\left.2 \mathrm{O}, 300 \mathrm{~K}\right): \delta=3.596$ (m, 2H; 8-H), 3.354 (s, 1.24H; 2-(Z)-H), 3.219 (s, 4.76H; 2-(E)-H), 2.477 (t, $J=7.6 \mathrm{~Hz}, 3.15 \mathrm{H} ; 4-(E)-\mathrm{H}), 2.365$ (m, 0.85H; 4-(Z)-H), 2.220 (t, $J=7.4 \mathrm{~Hz}, 4 \mathrm{H} ; 6-\mathrm{H}), 1.881(\mathrm{~m}, 2 \mathrm{H} ; 9 \mathrm{e}-\mathrm{H}), 1.803$ (p, $J=7.3 \mathrm{~Hz}, 4 \mathrm{H} ; 5-\mathrm{H}), 1.730$ (m, 2H; 10H), 1.299 (m, 4H; (10’9a)-H) ppm. 
${ }^{13} \mathrm{C}$ NMR (125.75 MHz, D $\left.20,298 \mathrm{~K}\right): \delta=176.50$ (7-C), 176.03 (3-C), 53.83 (8-C), 39.76 (2(Z)-C), 37.05 (2-(E)-C), 36.44 (6-(E)-C), 36.18 (6-(Z)-C), 32.69 (9-C), 32.56 (4-(Z)-C), 31.94 (4-(E)-C), 25.29 (10-C), 22.15 (5-C) ppm.

Elemental analysis calcd for $\mathrm{C}_{18} \mathrm{H}_{32} \mathrm{~N}_{4} \mathrm{O}_{6}$ (400.47): C 53.99\%; H 8.05\%; $\mathrm{N} 13.99 \%$. Found, C $53.51 \%$; H $8.41 \%$; N $13.76 \%$.

MALDI-TOF MS: Calcd for $\left[\mathrm{C}_{18} \mathrm{H}_{32} \mathrm{~N}_{4} \mathrm{O}_{6}+\mathrm{H}\right]^{+}$401.239, found 401.168; Calcd for $\left[\mathrm{C}_{18} \mathrm{H}_{32} \mathrm{~N}_{4} \mathrm{O}_{6}+\mathrm{Na}\right]^{+}$423.221, found 423.154; Calcd for $\left[\mathrm{C}_{18} \mathrm{H}_{32} \mathrm{~N}_{4} \mathrm{O}_{6}+\mathrm{K}\right]^{+}$439.195, found 439.138 . 


\section{NMR spectra}

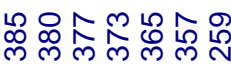

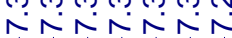

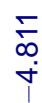

œ ఫ유

ம่ N N N N N N N

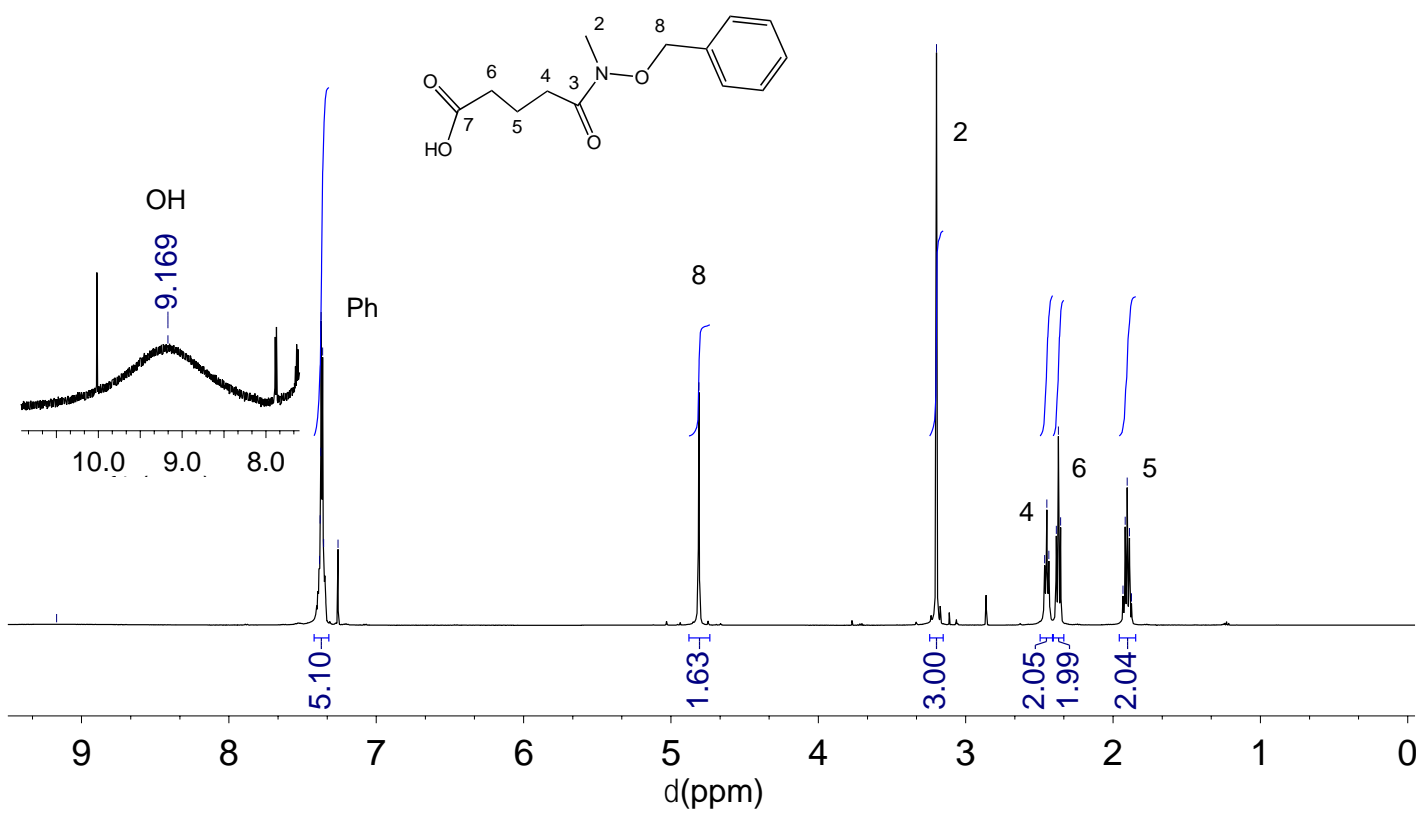

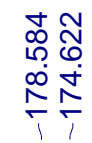

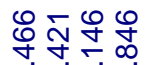

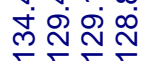

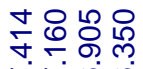

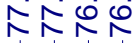

సิ듀뉴

लुल क्ष

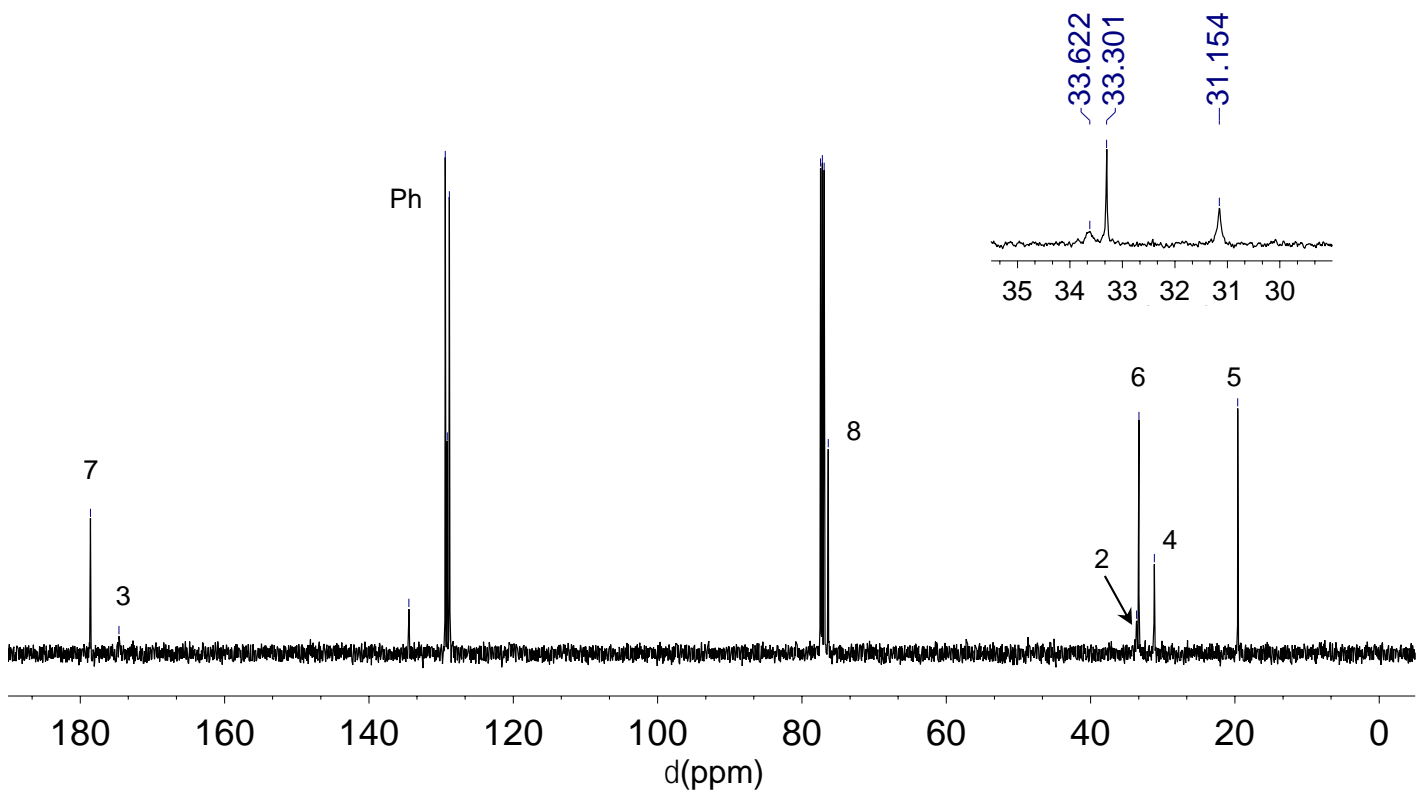

Fig. S1. ${ }^{1} \mathrm{H}$ (top) and ${ }^{13} \mathrm{C}$ (bottom) NMR spectra of 1 recorded in $\mathrm{CDCl}_{3}$ at $300 \mathrm{~K}$. 


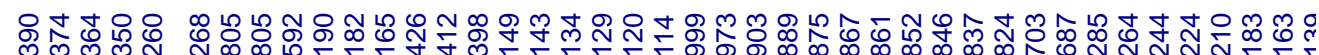

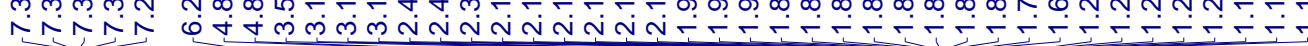

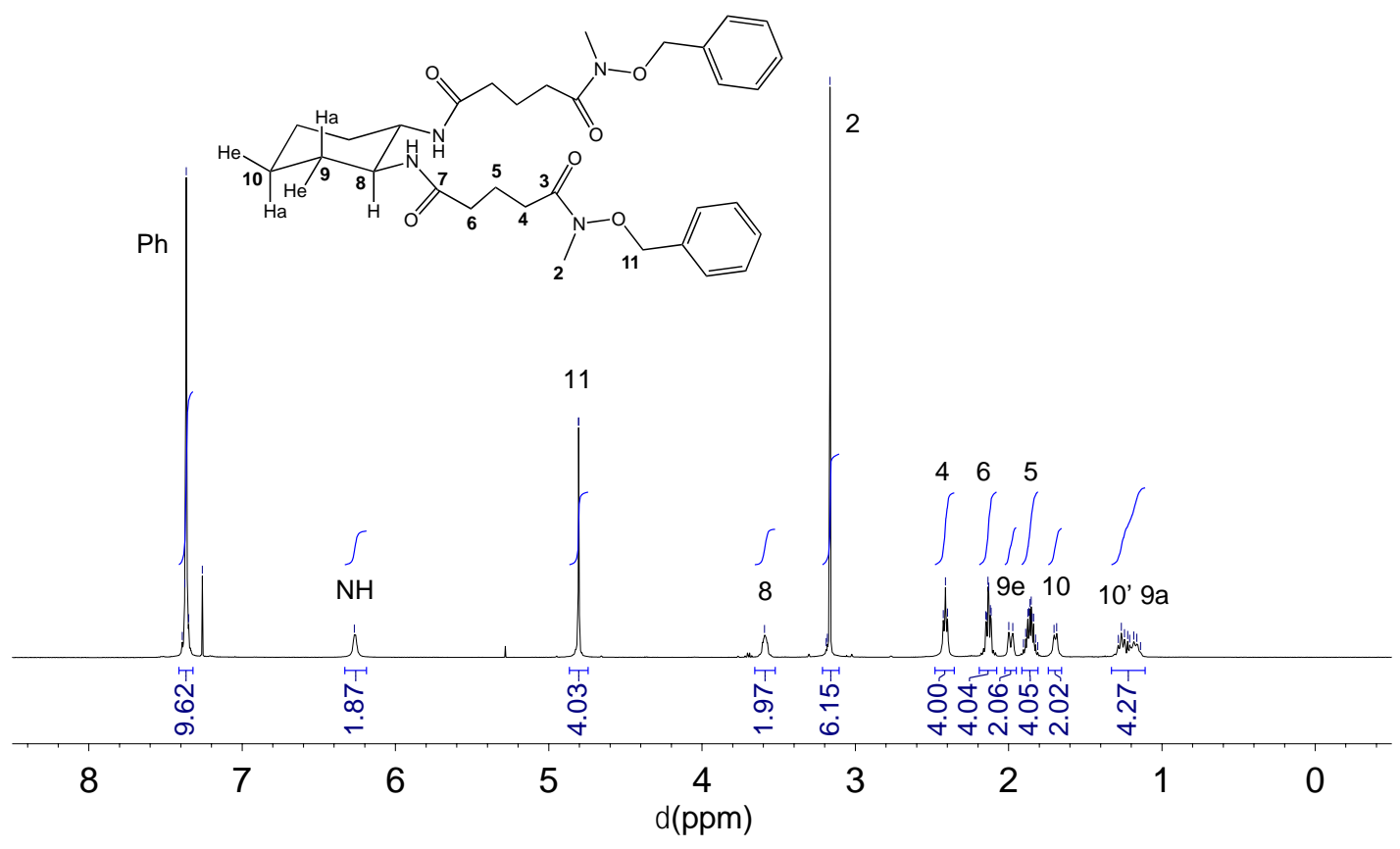

\begin{tabular}{|c|c|c|c|}
\hline 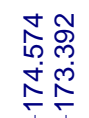 & 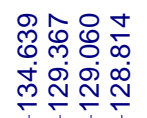 & 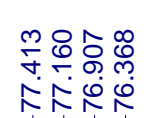 & 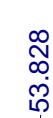 \\
\hline
\end{tabular}

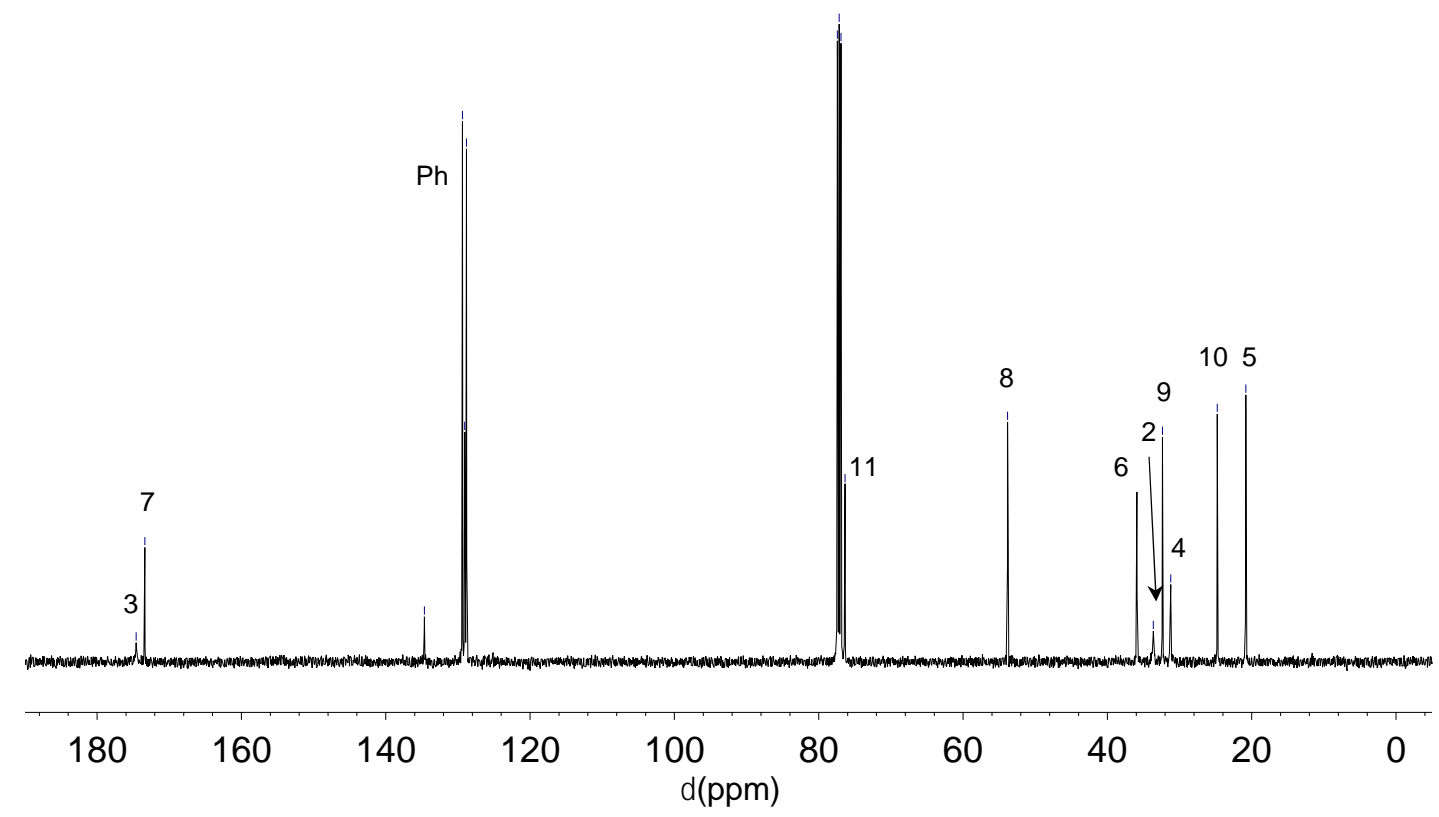

Fig. S2. ${ }^{1} \mathrm{H}$ (top) and ${ }^{13} \mathrm{C}$ (bottom) NMR spectra of 2 recorded in $\mathrm{CDCl}_{3}$ at $300 \mathrm{~K}$. 


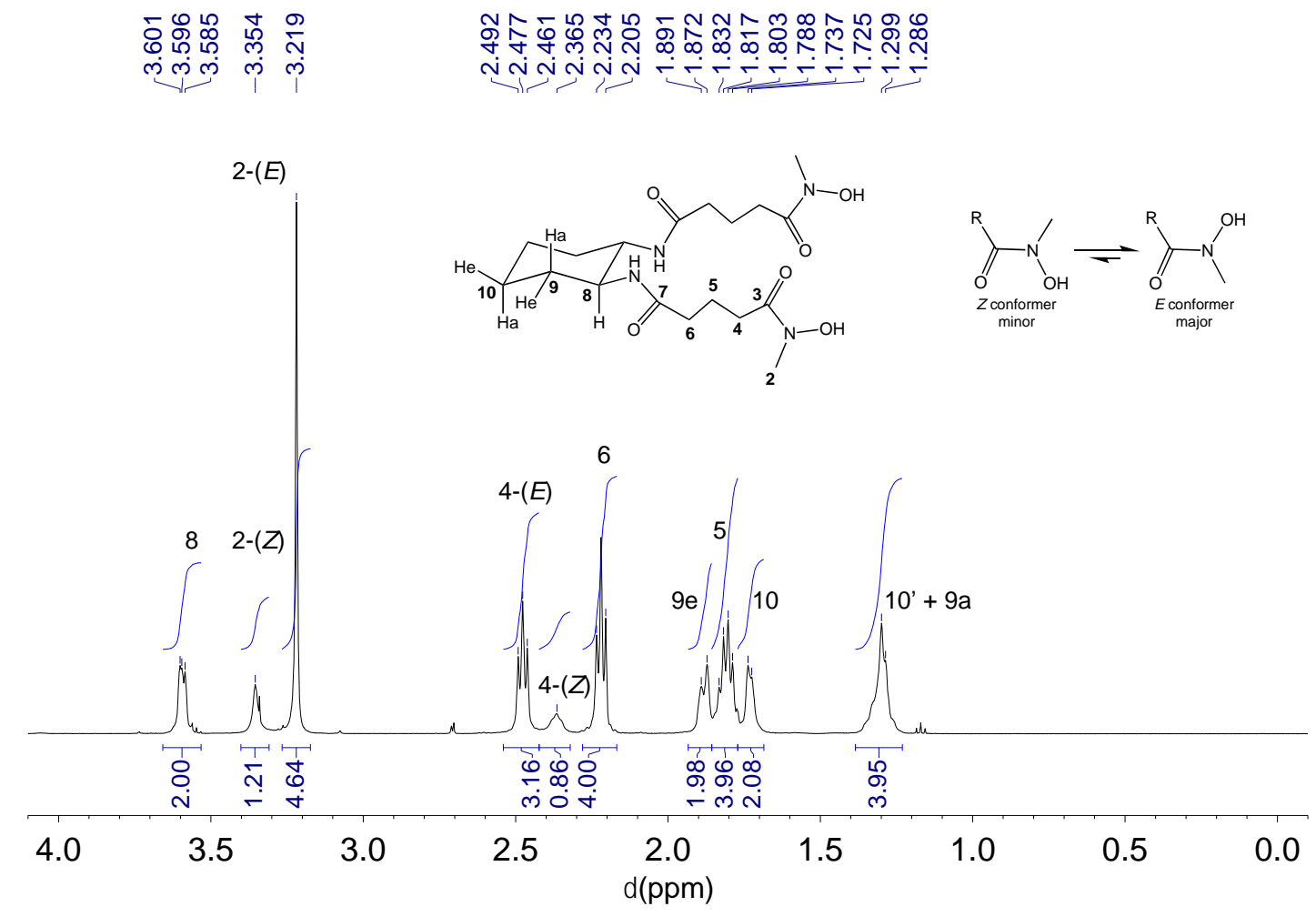

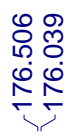

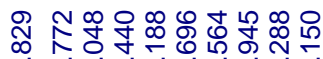

गुं
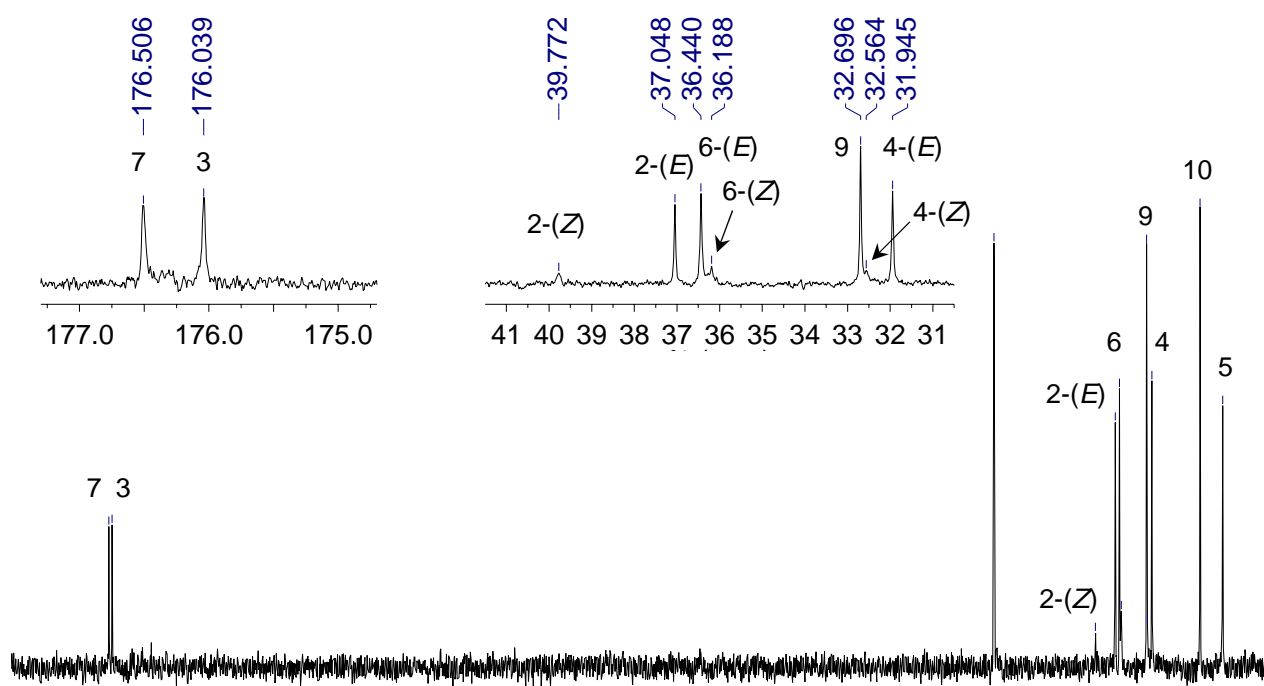

\begin{tabular}{|c|c|c|c|c|c|c|c|c|c|}
\hline 180 & 160 & 140 & 120 & 100 & 80 & 60 & 40 & 20 & 0 \\
\hline
\end{tabular}

Fig. S3. ${ }^{1} \mathrm{H}$ (top) and ${ }^{13} \mathrm{C}$ (bottom) NMR spectra of $\left(\mathrm{L}^{\mathrm{Cy}, \mathrm{Pr}}\right) \mathrm{H}_{2}$ recorded in $\mathrm{D}_{2} \mathrm{O}$ at $300 \mathrm{~K}$. 


\section{Solution thermodynamic studies}

3.1. $\mathrm{UO}_{2}{ }^{2+} / \mathrm{DFB}^{3-}$ system

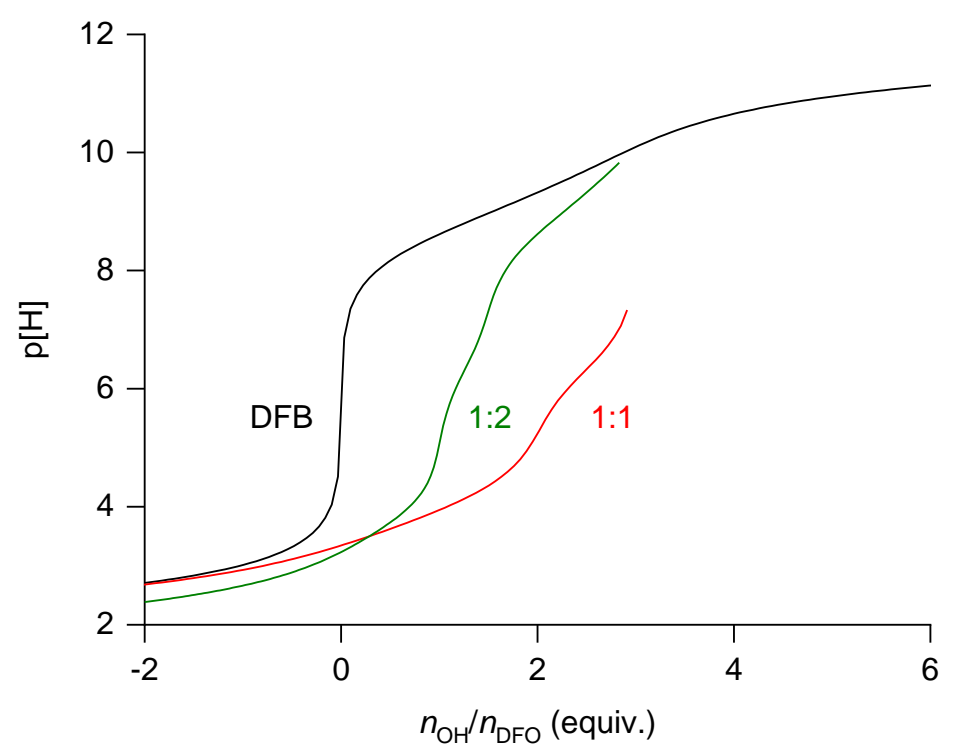

Fig. S4. Potentiometric titration curves of DFB alone (black line) and in the presence of one (red line) or two equivalents of $\mathrm{UO}_{2}{ }^{2+}$ (green line) with $0.1 \mathrm{M} \mathrm{KOH}$. I = 0.1 M KNO $3, \mathbf{T}=\mathbf{2 9 8 . 2 ( 1 )}$ K. $[\mathrm{DFB}]_{\mathrm{tot}}=\mathbf{1 . 0} \times 10^{-3} \mathrm{M}\left(\right.$ (BLACK LINE) $;[\mathbf{U}(\mathbf{V I})]_{\text {тот }}=[\mathrm{DFB}]_{\mathrm{tot}}=\mathbf{1 . 0} \times 10^{-3} \mathrm{M}($ red line $) ;[\mathbf{U}(\mathbf{V I})]_{\mathrm{tot}}=\mathbf{1 . 0}$ $\times 10^{-3} \mathrm{M},[\mathrm{DFB}]_{\text {Tот }}=\mathbf{2 . 0} \times 10^{-3} \mathrm{M}($ GREEN LINE $)$.

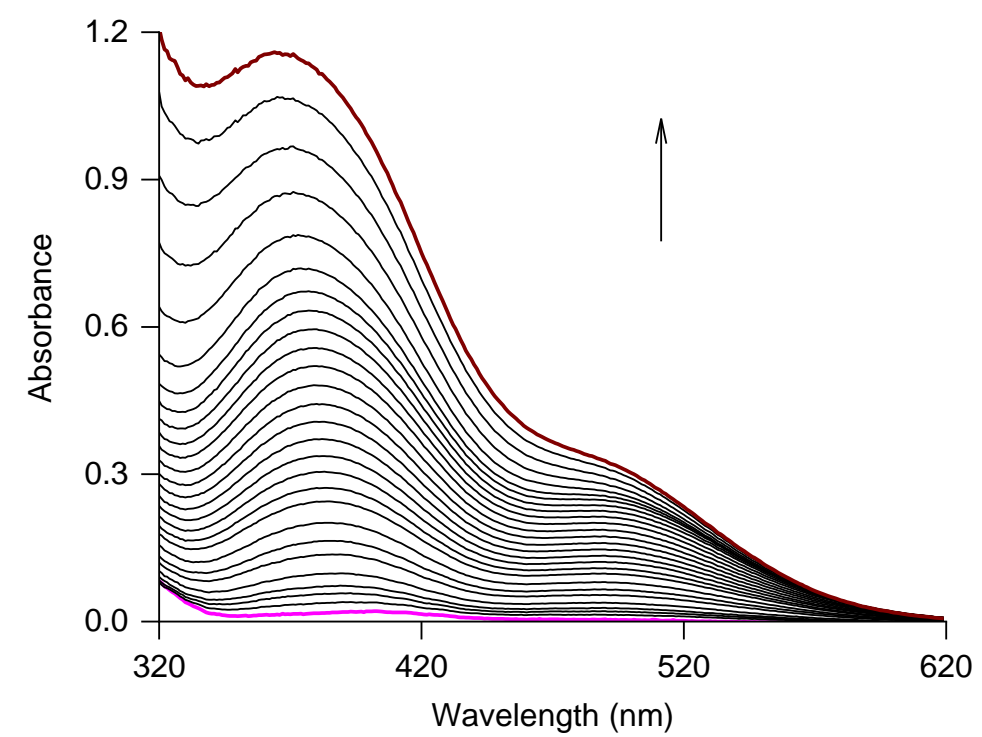

Fig. S5. Spectrophotometric titration of the $\mathrm{UO}_{2}{ }^{2+} / \mathrm{DFB}^{3-}$ system as a function of $\mathrm{p}[\mathrm{H}]$ with 0.1 M KOH. I = 0.1 $\mathbf{M ~ K N O}_{3}, \mathbf{T}=\mathbf{2 9 8 . 2 ( 1 )} \mathbf{K},[\mathrm{U}(\mathrm{VI})]_{\text {тот }}=[\mathrm{DFB}]_{\mathrm{Toт}}=\mathbf{1 . 0} \times \mathbf{1 0}^{-3} \mathbf{M}, \mathbf{P}[\mathbf{H}]=\mathbf{2 . 2 - 7 . 8}$, optical path 
length: L $=1$ CM. ABSORBANCE VALUES WERE CORRECTED FOR DILUTION EFFECTS.

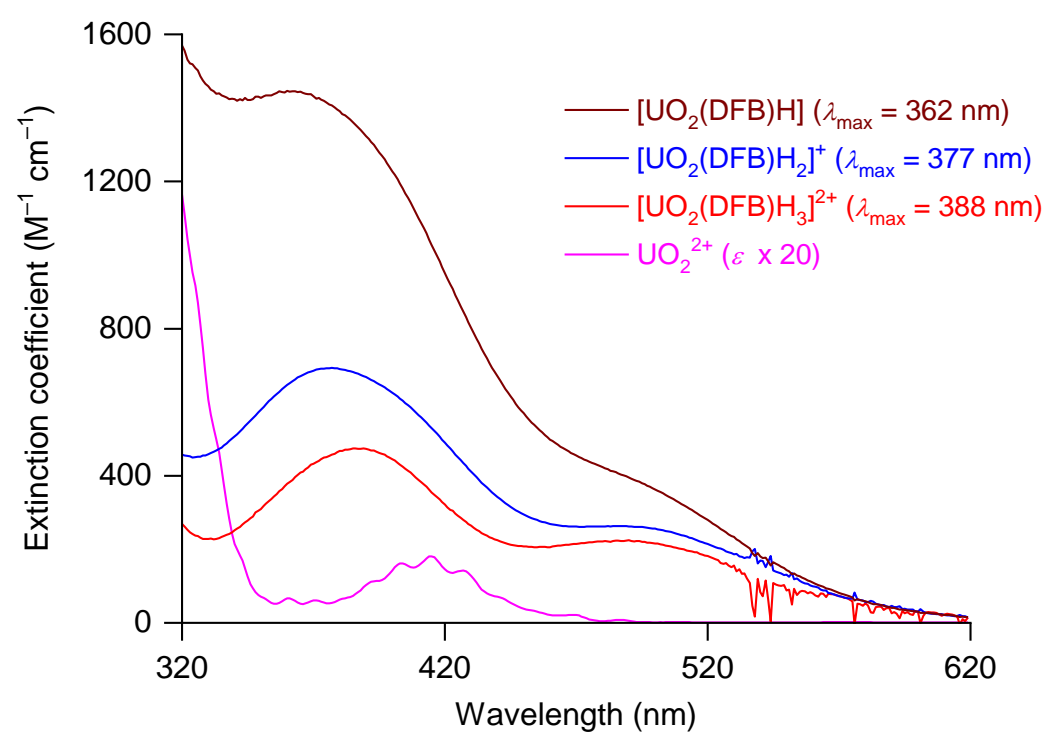

Fig. S6. Calculated electronic absorption spectra for the $\mathrm{UO}_{2}{ }^{2+} / \mathrm{DFB}^{3-}$ system. $I=0.1 \mathrm{M} \mathrm{KNO}_{3}$, $T=298.2(1) \mathrm{K}$.

\section{Table S1}

Absorption properties of the $\mathrm{UO}_{2}{ }^{2+} / \mathrm{DFB}^{3-}$ complexes. ${ }^{\mathrm{a}}$

\begin{tabular}{lll}
\hline Complex & $\lambda_{\max }(\mathrm{nm})$ & $\varepsilon_{\max }\left(\mathrm{M}^{-1} \mathrm{~cm}^{-1}\right)$ \\
\hline$\left[\left(\mathrm{UO}_{2}\right)(\mathrm{DFB}) \mathrm{H}_{3}\right]^{2+}$ & 388 & 473 \\
{$\left[\left(\mathrm{UO}_{2}\right)(\mathrm{DFB}) \mathrm{H}_{2}\right]^{+}$} & 377 & 693 \\
{$\left[\left(\mathrm{UO}_{2}\right)(\mathrm{DFB}) \mathrm{H}\right]$} & 362 & 1446 \\
\hline $\mathrm{a} \quad I=0.1 \mathrm{M} \mathrm{KNO}_{3}, T=298.2 \mathrm{~K}$ & &
\end{tabular}


3.2. $\mathrm{UO}_{2}{ }^{2+} /\left(L^{\mathrm{Cy}, \mathrm{Pr}}\right)^{2-}$ system

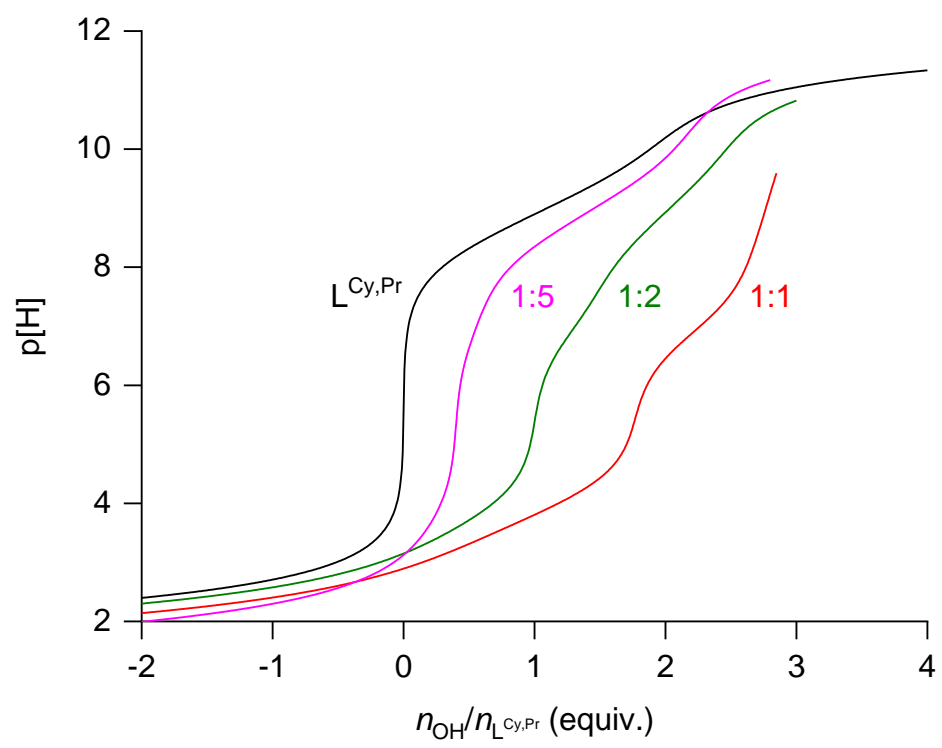

Fig. S7. Potentiometric titration curves of $\left(\mathrm{L}^{\mathrm{Cy}, \mathrm{Pr}}\right) \mathrm{H}_{2}$ alone (black line) and in the presence of one (red line), two (green line), or five equivalents of $\mathrm{UO}_{2}{ }^{2+}$ (magenta line) with $0.1 \mathrm{M} \mathrm{KOH}$. I $=0.1 \mathrm{M} \mathrm{KNO}_{3}, \mathbf{T}=\mathbf{2 9 8 . 2 ( 1 )} \mathbf{K} .\left[\mathrm{L}^{\mathrm{Cy}, \mathrm{Pr}}\right]_{\mathrm{tot}}=2.0 \times 10^{-3} \mathrm{M}$ (BLACK LINE); $[\mathrm{U}(\mathrm{VI})]_{\mathrm{Tot}}=3.0 \times 10^{-3} \mathrm{M},\left[\mathrm{L}^{\mathrm{Cy}, \mathrm{Pr}}\right]_{\text {tot }}$ $=3.4 \times 10^{-3} \mathrm{M}$ (red line); [U(VI) $]_{\text {тот }}=\mathbf{1 . 2} \times \mathbf{1 0}^{-3} \mathbf{M},\left[\mathrm{L}^{\mathrm{Cy}, \mathrm{Pr}}\right]_{\mathrm{Tot}}=\mathbf{2 . 4} \times \mathbf{1 0 ^ { - 3 }} \mathbf{M}($ GREEN LINE $),[\text { U(VI) }]_{\text {тот }}=1.0$ $\times 10^{-3} \mathbf{M},\left[\mathrm{L}^{\mathrm{Cy}, \mathrm{Pr}}\right]_{\text {тот }}=\mathbf{5 . 0} \times 10^{-3} \mathrm{M}$ (MAGENTA LiNe).

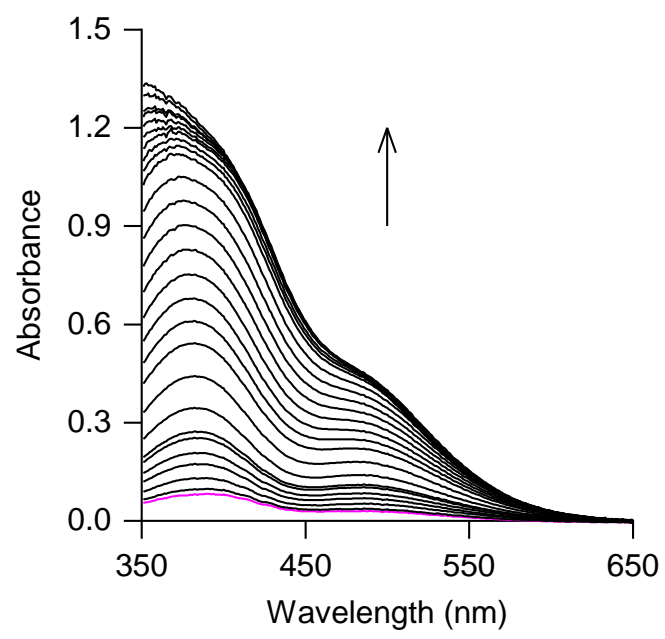

(a)

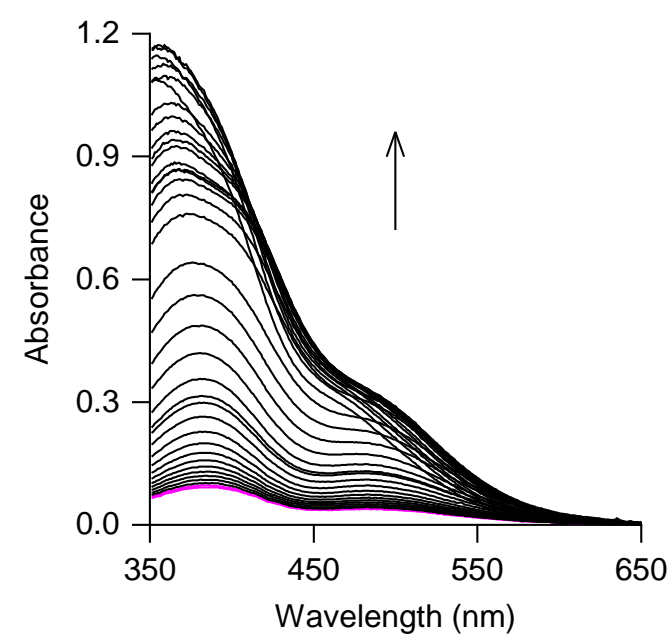

(b)

Fig. S8. Spectrophotometric titration of the $\mathrm{UO}_{2}{ }^{2+} /\left(\mathrm{L}^{\mathrm{Cy}}, \mathrm{Pr}\right)^{2-}$ system as a function of $\mathrm{p}[\mathrm{H}]$ with 0.1 M KOH. I = 0.1 M KNO 3 , T = 298.2(1) K, optical path length: $\mathbf{L}=\mathbf{1} \mathbf{C M}$. (A) $[\mathbf{U}(\mathbf{V I})]_{\mathrm{Tot}}=\left[\mathrm{L}^{\mathrm{Cy}}, \mathrm{Pr}_{\mathrm{rot}}=\right.$ $2.3 \times 10^{-3} \mathrm{M}, \mathbf{P}[\mathrm{H}]=\mathbf{2 . 1 2 - 6 . 6 4}$. (в) $[\mathrm{U}(\mathrm{VI})]_{\text {тот }}=1.15 \times 10^{-3} \mathrm{M},\left[\mathrm{L}^{\mathrm{Cy}, \mathrm{Pr}}\right]_{\mathrm{Tот}}=\mathbf{2 . 3 0} \times 10^{-3} \mathrm{M}, \mathbf{P}[\mathrm{H}]=\mathbf{2 . 3 3 - 9 . 0 2}$. 


\section{ABSORBANCE VALUES WERE CORRECTED FOR DILUTION EFFECTS.}
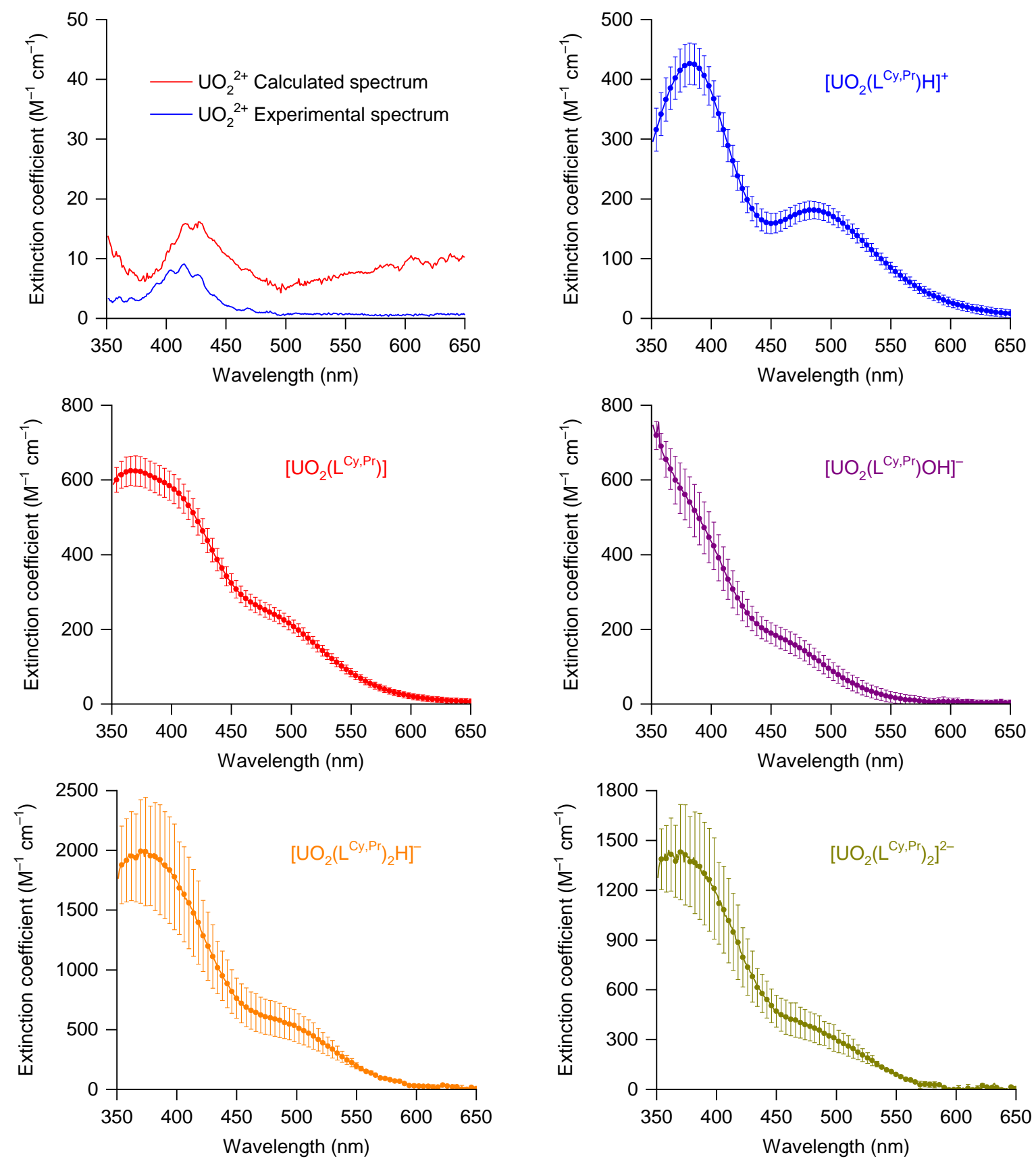

Fig. S9. Calculated mean electronic absorption spectra for the $\mathrm{UO}_{2}{ }^{2+} /\left(\mathrm{L}^{\mathrm{Cy}, \mathrm{Pr}}\right)^{2-}$ system. Error bars correspond to the standard deviations for four (1:1 species) or two (1:2) independent spectrophotometric titrations processed with the HypSpec program by fixing the values of the equilibrium constants obtained by the global treatment of eleven potentiometric data sets. Only one point over four is displayed for sake of clarity. $I=0.1 \mathrm{M} \mathrm{KNO}_{3}, T=298.2(1) \mathrm{K}$. 
3.3. $\mathrm{Fe}^{3+} /\left(\mathrm{L}^{\mathrm{Cy}, \mathrm{Pr}}\right)^{2-}$ system

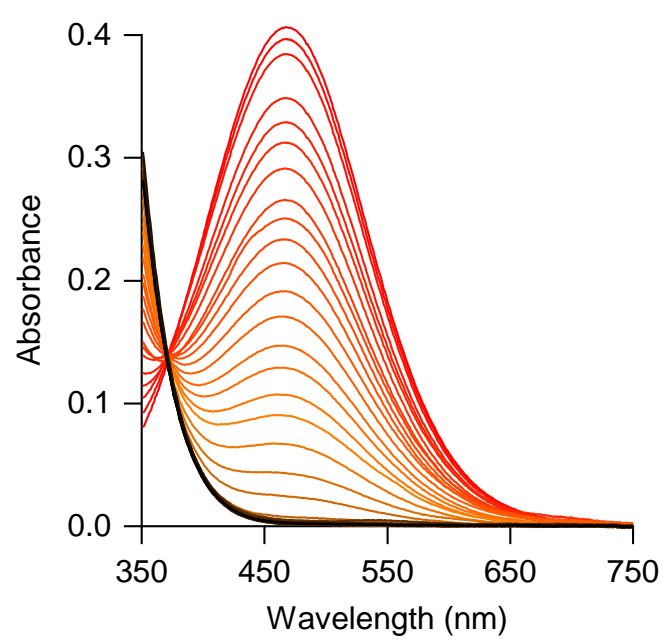

(a)

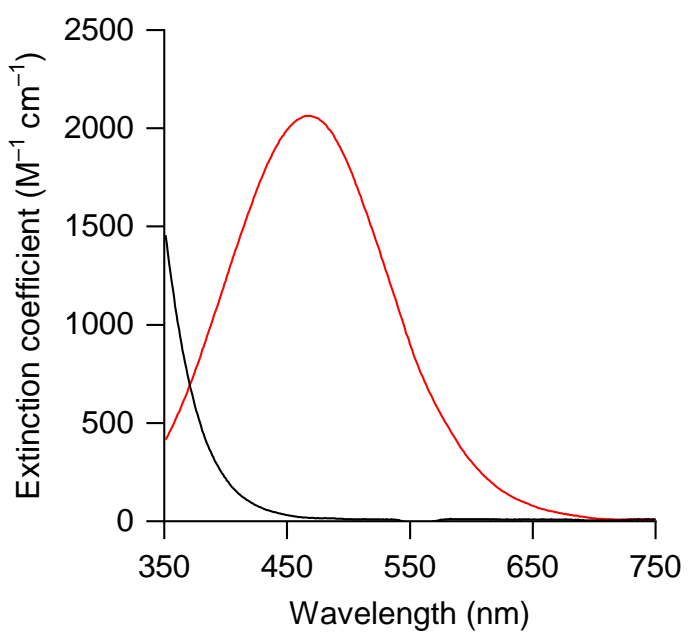

(b)

Fig. S10. (a) Spectrophotometric competition titration of the $\mathrm{Fe}^{3+} /\left(\mathrm{L}^{\mathrm{Cy}, \mathrm{Pr}}\right)^{2-}$ system with increasing amounts of $\mathrm{Na}_{2} \mathrm{H}_{2}$ EDTA. $I=0.1 \mathrm{M} \mathrm{KNO}_{3}, \mathrm{p}[\mathrm{H}]=2.8,\left[\mathrm{ClCH}_{2} \mathrm{CO}_{2} \mathrm{H} / \mathrm{ClCH}_{2} \mathrm{CO}_{2}{ }^{-}\right]$ $=0.05 \mathrm{M}, T=298.2(1) \mathrm{K},[\mathrm{Fe}(\mathrm{III})]_{\mathrm{tot}}=1.99 \times 10^{-4} \mathrm{M},\left[\mathrm{L}^{\mathrm{Cy}, \mathrm{Pr}}\right]_{\mathrm{tot}}=2.0 \times 10^{-4} \mathrm{M}, 0 \leq$ $\left[\mathrm{Na}_{2} \mathrm{H}_{2} \text { EDTA }\right]_{\text {tot }} \leq 5.0 \times 10^{-4} \mathrm{M}$ (red to black spectra), optical path length: $l=1 \mathrm{~cm}$. (b) Calculated electronic absorption spectra of $\left[\mathrm{Fe}\left(\mathrm{L}^{\mathrm{Cy}, \mathrm{Pr}}\right)\right]^{+}$(red line) and $[\mathrm{Fe}(\mathrm{EDTA})]^{-}$(black line).

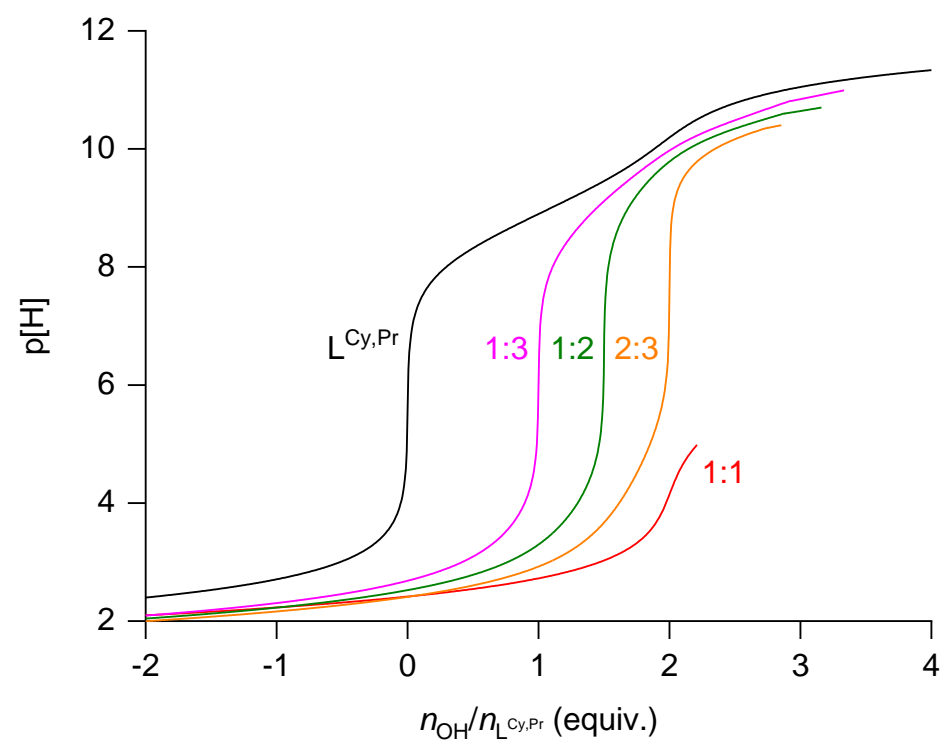

Fig. S11. Potentiometric titration curves of $\left(\mathrm{L}^{\mathrm{Cy}, \mathrm{Pr}}\right) \mathrm{H}_{2}$ alone (black line) and in the presence of one (red line), one and a half (orange), two (green line), or three equivalents of $\mathrm{Fe}^{3+}$ (magenta line) with $0.1 \mathrm{M} \mathrm{KOH}$. I $=\mathbf{0 . 1} \mathbf{M ~ K N O}_{3}, \mathbf{T}=\mathbf{2 9 8 . 2 ( 1 )} \mathbf{K}$. $\left[\mathrm{L}^{\mathrm{Cy}, \mathrm{Pr}}\right]_{\mathrm{tot}}=2.0 \times 10^{-3} \mathrm{M}$ (BLACK LINE);

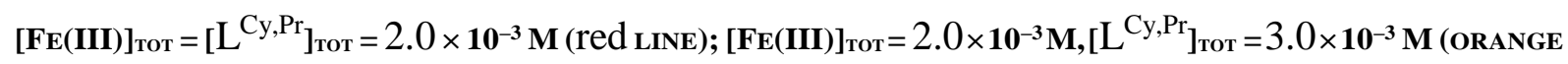


LINE); $[\mathbf{F e}(\mathbf{I I I})]_{\mathrm{Tot}}=1.5 \times 10^{-3} \mathrm{M},\left[\mathrm{L}^{\mathrm{Cy}, \mathrm{Pr}}\right]_{\mathrm{tot}}=3.0 \times 10^{-3} \mathrm{M}$ (green line); $[\mathbf{F E}(\mathbf{I I I})]_{\text {тот }}=1.0 \times \mathbf{1 0}^{-\mathbf{3}} \mathbf{M}$, $\left[\mathrm{L}^{\mathrm{Cy}, \mathrm{Pr}}\right]_{\text {Tot }}=3.0 \times 10^{-3} \mathbf{M}$ (MAgenta LiNe).

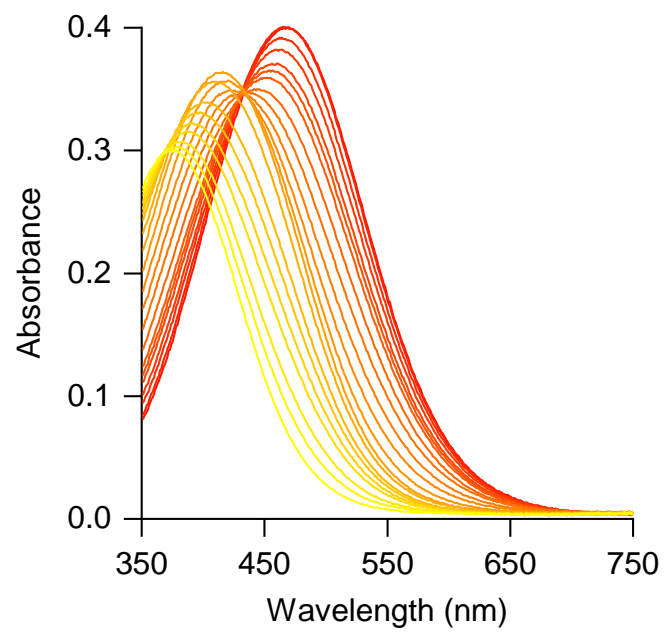

(a)

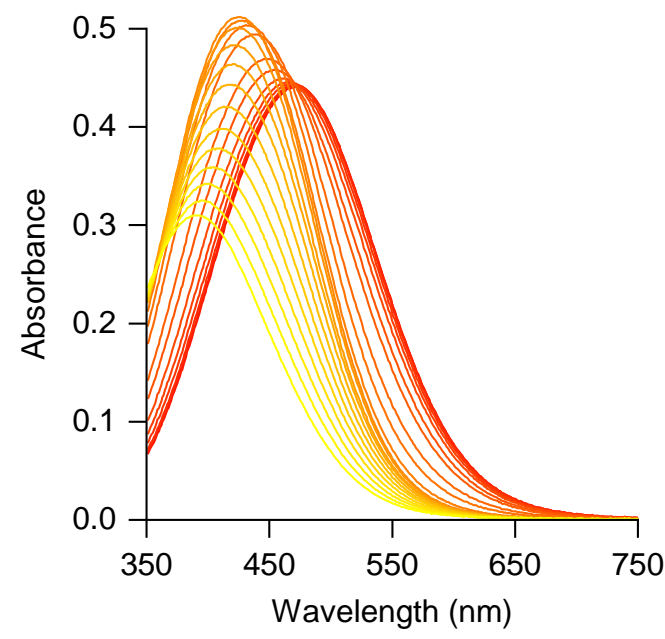

(b)

Fig. S12. Spectrophotometric titration of the $\mathrm{Fe}^{3+} /\left(\mathrm{L}^{\mathrm{Cy}, \mathrm{Pr}}\right)^{2-}$ system as a function of $\mathrm{p}[\mathrm{H}]$ with 0.1 M KOH. I = 0.1 M KNO, $\mathbf{T}=\mathbf{2 9 8 . 2 ( 1 ) ~ K , ~ o p t i c a l ~ p a t h ~ l e n g t h : ~} \mathbf{L}=\mathbf{1} \mathbf{C M}$. (A) $[\mathbf{F E}(\mathbf{I I I})]_{\mathrm{Tot}}=\left[\mathrm{L}^{\mathrm{Cy}, \mathrm{Pr}}\right]_{\mathrm{Tot}}=\mathbf{2}$ $\times 10^{-4} \mathrm{M}, \mathrm{P}[\mathrm{H}]=1.9-10.4$ (RED TO YELLOW SPECTRA), (B) $[\mathrm{FE}(\mathrm{III})]$ Tot $=2 \times 10^{-4} \mathrm{M},\left[\mathrm{L}^{\mathrm{Cy}}, \mathrm{Pr}\right]$ Tот $=3 \times 10^{-4} \mathrm{M}, \mathrm{P}[\mathrm{H}]=$ 2.09-10.51 (RED TO YELLOW SPECTRA). ABSORBANCE VALUES WERE CORRECTED FOR DILUTION EFFECTS.

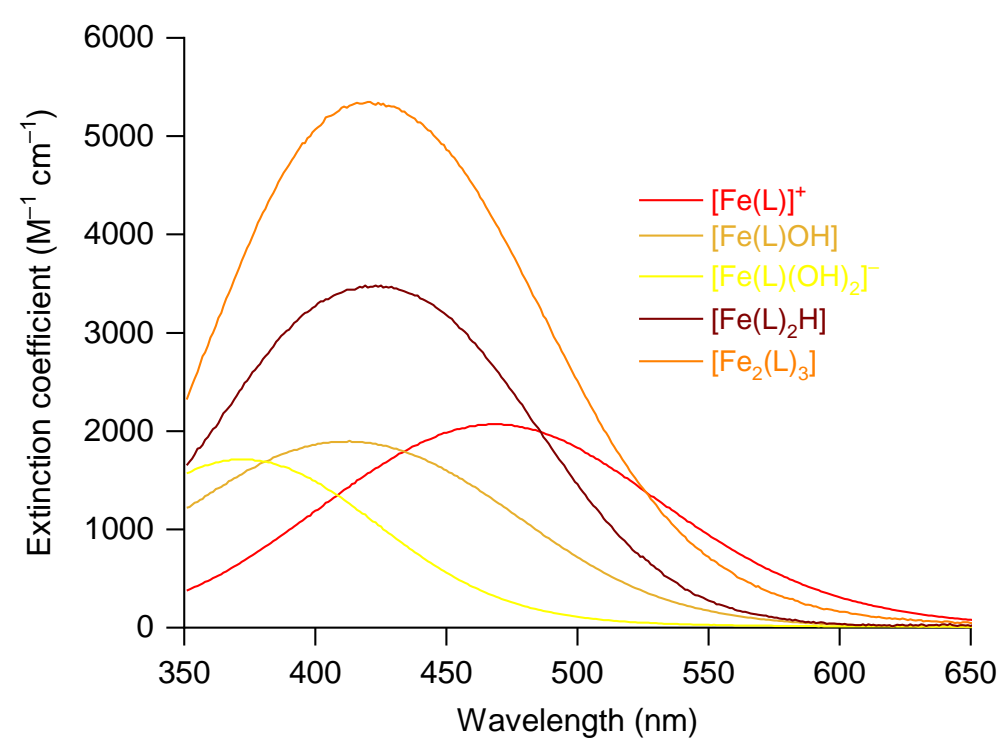

Fig. S13. Calculated electronic absorption spectra for the $\mathrm{Fe}^{3+} /\left(\mathrm{L}^{\mathrm{Cy}, \mathrm{Pr}}\right)^{2-}$ system obtained by the global fit of spectrophotometric titrations with the HypSpec program. $I=0.1 \mathrm{M} \mathrm{KNO}_{3}, T=$ 298.2(1) K. 


\section{Speciation simulations}

\section{Table S2}

Input concentrations used for the speciation calculations of $U$ and Fe after 7 days of contact in sealed batch reactors.

\begin{tabular}{lllll}
\hline & Soil 1 & \multicolumn{3}{l}{ Soil 2} \\
\cline { 2 - 5 } $\mathrm{pH}$ & 5.70 & 5.73 & 5.40 & 5.57 \\
\hline $\mathrm{Ca}^{2+}$ & $1.00 \times 10^{-4}$ & $1.00 \times 10^{-4}$ & $4.88 \times 10^{-5}$ & $4.88 \times 10^{-5}$ \\
$\mathrm{Mg}^{2+}$ & $3.70 \times 10^{-5}$ & $3.70 \times 10^{-5}$ & $1.75 \times 10^{-5}$ & $1.75 \times 10^{-5}$ \\
$\mathrm{~K}^{+}$ & $1.28 \times 10^{-4}$ & $1.28 \times 10^{-4}$ & $8.72 \times 10^{-5}$ & $8.72 \times 10^{-5}$ \\
$\mathrm{Na}^{+}$ & $2.61 \times 10^{-5}$ & $2.61 \times 10^{-5}$ & $2.28 \times 10^{-5}$ & $2.28 \times 10^{-5}$ \\
$\mathrm{Cl}^{-}$ & $1.01 \times 10^{-4}$ & $1.01 \times 10^{-4}$ & $7.04 \times 10^{-4}$ & $7.04 \times 10^{-4}$ \\
$\mathrm{NO}_{3}{ }^{-}$ & $3.71 \times 10^{-5}$ & $3.71 \times 10^{-5}$ & $6.45 \times 10^{-5}$ & $6.45 \times 10^{-5}$ \\
$\mathrm{SO}_{4}{ }^{2-}$ & $4.06 \times 10^{-5}$ & $4.06 \times 10^{-5}$ & $1.93 \times 10^{-5}$ & $1.93 \times 10^{-5}$ \\
$\mathrm{PO}_{4}{ }^{3-}$ & $7.89 \times 10^{-6}$ & $7.89 \times 10^{-6}$ & $2.89 \times 10^{-7}$ & $2.89 \times 10^{-7}$ \\
$\mathrm{UO}_{2}{ }^{2+}$ & $1.24 \times 10^{-6}$ & $2.31 \times 10^{-6}$ & $1.89 \times 10^{-6}$ & $1.53 \times 10^{-6}$ \\
$\mathrm{Fe}^{3+}$ & $4.29 \times 10^{-4}$ & $2.33 \times 10^{-4}$ & $4.41 \times 10^{-4}$ & $1.83 \times 10^{-4}$ \\
$\mathrm{DFB}^{-4}$ & $5.18 \times 10^{-4}$ & & $5.89 \times 10^{-4}$ & \\
$\left(\mathrm{~L}^{\mathrm{Cy}, \mathrm{Pr}}\right) \mathrm{H}_{2}$ & & & & $6.27 \times 10^{-4}$ \\
\hline
\end{tabular}




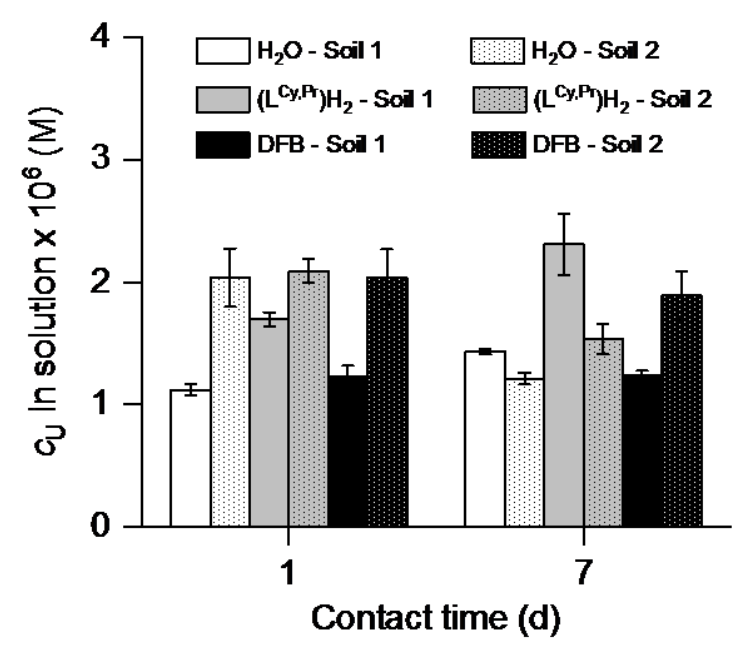

Fig. S14. Amount of uranium recovered in solution after 1 and 7 days of contact between the tested soils and the different extraction media (pure water, $10^{-3} \mathrm{M}\left(\mathrm{L}^{\mathrm{Cy}, \mathrm{Pr}}\right) \mathrm{H}_{2}$ or DFB solution) in sealed batch reactors.

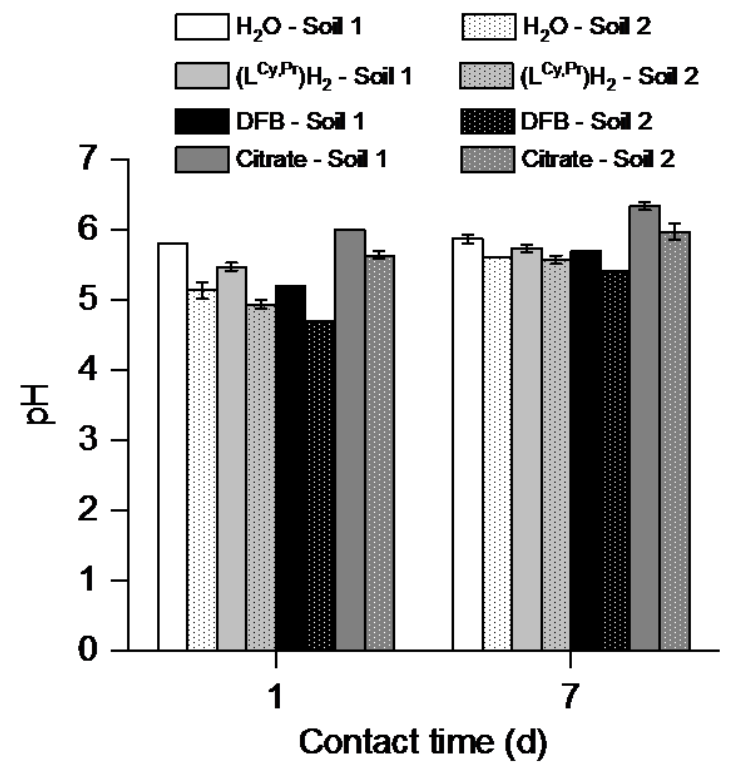

(a)

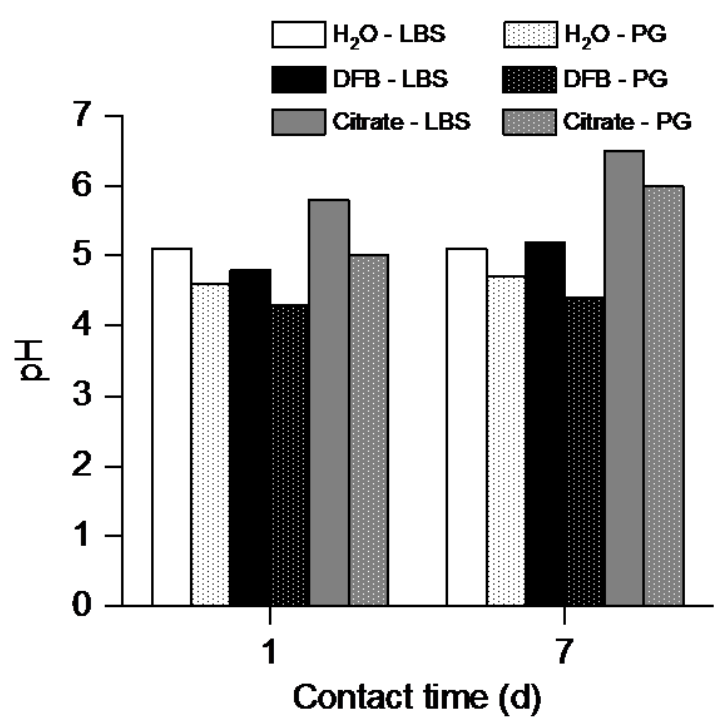

(b)

Fig. S15. $\mathrm{pH}$ values of the extraction media (pure water, $10^{-3} \mathrm{M}\left(\mathrm{L}^{\mathrm{Cy}, \mathrm{Pr}}\right) \mathrm{H}_{2}, \mathrm{DFB}$, or sodium citrate solution) after 1 and 7 days of contact with (a) the U- and (b) the Pu-contaminated soils in sealed batch reactors. 


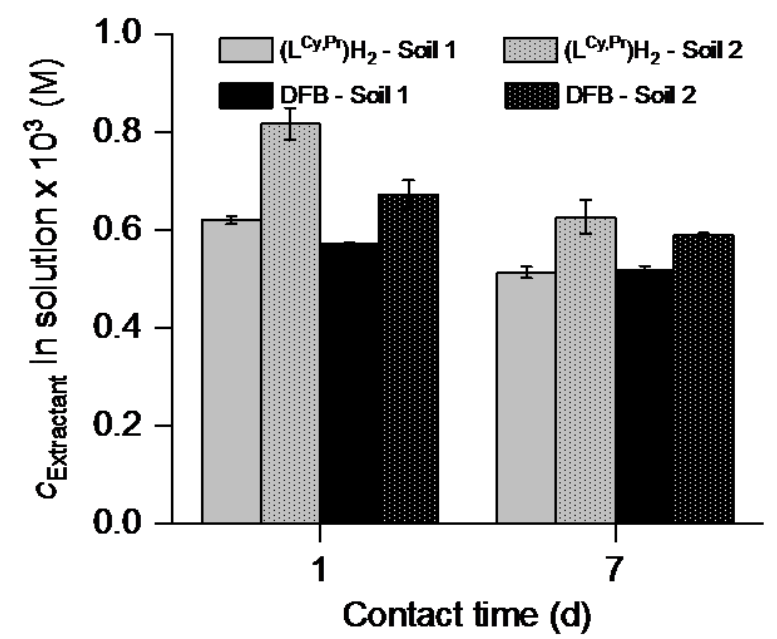

(a)

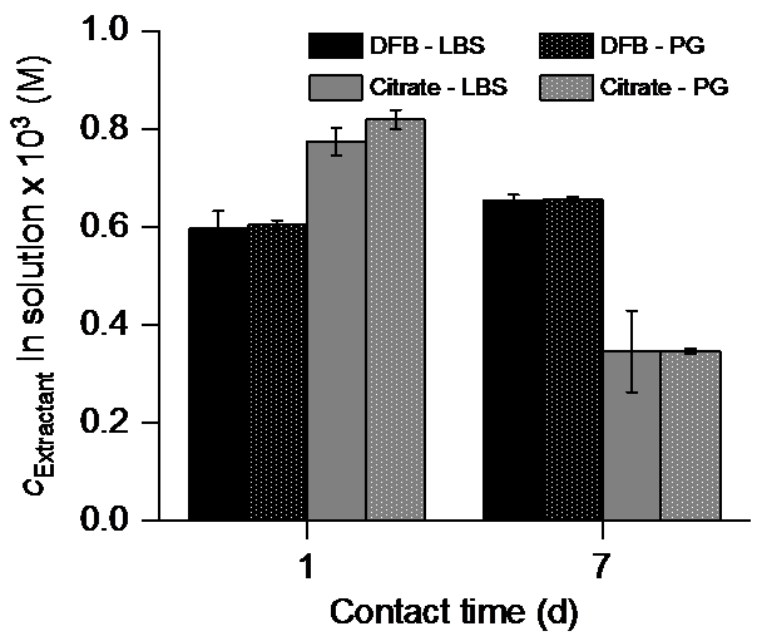

(b)

Fig. S16. Total concentrations of extractant remaining in the supernatants after 1 and 7 days of contact between (a) the U- and (b) the Pu-contaminated soils and the different extraction media $\left(10^{-3} \mathrm{M}\left(\mathrm{L}^{\mathrm{Cy}, \mathrm{Pr}}\right) \mathrm{H}_{2}, \mathrm{DFB}\right.$, or sodium citrate solution) in sealed batch reactors. 


\section{References}

[1] B.H. Lee, M. J. Miller, J. Org. Chem. 1983, 48, 24-31. DOI

[2] R. Sulsky, J. P. Demers, Tetrahedron Lett. 1989, 30, 31-34. DOI

[3] R. Grigg, Z. Rankovich, M. Thoroughgood, Tetrahedron Lett. 2000, 56, 8025-8032. DOI

[4] S. K. Sharma, M. J. Miller, S. M. Payne, J. Med. Chem. 1989, 32, 357-367. DOI 